UNIVERSIDADE DE SÃO PAULO

FACULDADE DE EDUCAÇÃO

FERNANDO VIZOTTO GALVÃO

\title{
GASTOS COM EDUCAÇÃO E DESEMPENHO ESCOLAR: \\ UMA ANÁLISE NO NÍVEL DA ESCOLA
}

São Paulo

2016 
FERNANDO VIZOTTO GALVÃO

GASTOS COM EDUCAÇÃO E DESEMPENHO ESCOLAR:

UMA ANÁLISE NO NÍVEL DA ESCOLA

Dissertação apresentada ao Programa de PósGraduação da Faculdade de Educação da Universidade de São Paulo para a obtenção do título de Mestre em Educação.

Área de concentração: Estado, Sociedade e Educação

Orientador: Prof. Dr. Romualdo Luiz Portela de Oliveira.

Versão Revisada

São Paulo

2016 
AUTORIZO A REPRODUÇÃO E DIVULGAÇÃO TOTAL OU PARCIAL DESTE TRABALHO, POR QUALQUER MEIO CONVENCIONAL OU ELETRÔNICO, PARA FINS DE ESTUDO E PESQUISA, DESDE QUE CITADA A FONTE.

Catalogação na Publicação

Serviço de Biblioteca e Documentação

Faculdade de Educação da Universidade de São Paulo

379.32

G182g
Galvão, Fernando Vizotto

Gastos com educação e desempenho escolar: uma análise no nível da escola / Fernando Vizotto Galvão; orientação Romualdo Luiz Portela de Oliveira. São Paulo: s. n., 2016.

123 p.; grafs; tabs.; anexos

Dissertação (Mestrado - Programa de Pós-Graduação em Educação. Área de Concentração: Estado, Sociedade e Educação) - - Faculdade de Educação da Universidade de São Paulo.

1. Gastos com educação 2. Desempenho escolar 3. Recursos escolares 4. Financiamento da educação 5. Gastos públicos - Educação I. Oliveira, Romualdo Luiz Portela de, orient. 


\title{
FOLHA DE APROVAÇÃO
}

\author{
Fernando Vizotto Galvão
}

Gastos com educação e desempenho escolar: uma análise no nível da escola

Dissertação apresentada ao Programa de PósGraduação da Faculdade de Educação da Universidade de São Paulo para a obtenção do título de Mestre em Educação.

Aprovado em:

Banca examinadora:

Prof. Dr.

Instituição:

Assinatura:

Prof. Dr.

Instituição:

Assinatura:

Prof. Dr.

Instituição:

Assinatura: 
Para Daisy. 


\section{Agradecimentos}

À Secretaria Municipal de Educação de São Bernardo do Campo, por tornar essa pesquisa possível. Em especial, à Maria Helena Negreiros de Oliveira, por viabilizar o acesso aos dados e por toda ajuda com esclarecimentos e comentários que contribuíram para a realização deste trabalho;

Ao meu orientador, Romualdo, por me guiar em um campo que, no início, eu pouco conhecia. Pela paciência, indicações de leitura, pelos contatos estabelecidos, pelos comentários e correções de rota, por viabilizar esta pesquisa. Por ter compartilhado comigo um pouco de um tanto que ainda tenho a conhecer;

Aos orientandos do professor Romualdo, que desde o início contribuíram com comentários e sugestões e que me incluíram em um ambiente de colaboração e compartilhamento de conhecimento e de experiências;

Aos professores Robert Evan Verhine e Fernando Luiz Abrucio, pelos questionamentos e recomendações no exame de qualificação. Ao professor Rubens Barbosa de Camargo, pelo acesso a um rico material de pesquisa, que me ajudou a ter uma boa ideia dos recursos existentes em uma escola;

Ao Daniel Rosembaum, à Malena Carvalho, à Gabriela Thomazinho e à professora Adriana Backx Noronha Viana, pela ajuda, comentários e recomendações nos momentos finais deste trabalho.

À professora Denice Barbara Catani, que por três semestres nos conduziu por leituras que me impactaram de muitas formas, e que ampliaram minha compreensão sobre o "ofício de pesquisador";

Aos meus pais, por me ajudarem a chegar até aqui. Pelo apoio incondicional, nos estudos e na vida;

À Daisy, por me ajudar a continuar e também a parar, quando precisava parar. Por me acompanhar em todas as coisas. Por deixar um pouco de sua sensibilidade e talento registrados nas páginas que se seguem;

A Deus, pela vida e por continuar me mostrando que a ampliação do conhecimento é também a ampliação das possibilidades de conhecê-Lo. 
Le capitaine Jonathan, Etant âgé de dix-huit ans, Capture um jour um um pélican Dans une île d'Extrême-Orient. Le pélican de Jonathan, Au matin, pond un oeuf tout blanc Et il en sort un pélican Lui ressemblant étonnamment. Et ce deuxième pélican Pond, à son tour, un oeuf tout blanc D'où sort, inévitablement, Un autre Qui en fait autant. Cela peut durer très longtemps Si l'on ne fait pas d'omelette avant.

Robert Desnos 


\section{RESUMO}

Esta dissertação tem como objetivo explorar a relação entre gastos com educação e desempenho escolar, a partir de informações de gastos no nível das escolas. O debate em torno da relação entre gastos e desempenho, em geral, tem se baseado em estimativas que utilizam dados agregados de gastos municipais com educação. Dessa forma, como pouco se sabe a respeito do que é feito, na prática, com os recursos destinados às escolas, as pesquisas se restringem ao apontamento da existência ou não de uma relação entre gastos agregados com educação e desempenho. Neste trabalho, indicamos a relevância da informação de gastos no nível da escola, segundo categorias de agregação dos gastos que apontem para determinadas funções ou atividades escolares, para que se possa avançar no sentido de compreender não somente se gastos com educação estão ou não associados ao desempenho, mas como diferentes tipos de gastos, associados a diferentes atividades escolares, estão relacionados de diferentes formas ao desempenho dos alunos. Assim, com base na revisão da literatura pertinente, elaboramos uma proposta de categorias de gastos com pessoal, para as escolas da rede municipal de São Bernardo do Campo, que esteja alinhada às atividades desenvolvidas pelas escolas, sendo as categorias de maior agregação as que dizem respeito ao que consideramos Gastos diretamente relacionados ao ensino e Gastos indiretamente relacionados ao ensino. A partir das categorias delimitadas, baseadas nas informações de gastos por escola, exploramos a relação entre gasto por aluno e desempenho em matemática na prova Brasil de 2013, por meio de análise de regressão. As estimativas revelaram que a relação entre gastos e desempenho não é homogênea entre as diferentes categorias de gasto e que a especificação dos modelos melhora na medida em que os gastos são desagregados. Dentre os resultados obtidos, destacamos aquele que indica uma relação positiva e significante entre os gastos com Coordenação pedagógica e o desempenho em matemática.

Palavras-chave: gastos com educação; desempenho escolar; gastos no nível da escola; recursos escolares 


\begin{abstract}
This dissertation aims to explore the relationship between the money spent on education and school performance, based on the information about spending at the school-level. The debate on the relationship between expense and performance has been mostly based on estimates using the aggregated data of municipal spending on education. Thus, as little is known about what is actually done with the resources allocated to schools, researches on this subject are restricted to indicating the existence or the lack of a relationship between aggregate spending and performance. In this study, we show the relevance of the information on spending at the school level, according to categories of aggregate spending that point to certain functions or school activities. With this, we intend not only to understand if education expenses are or are not associated with performance, but also to observe how different types of costs associated with different school activities are related in different ways to the performance of students. Thus, based on literature review, we have proposed categories of personnel expenses for the municipal schools of São Bernardo do Campo, which are aligned to the activities developed by the schools. Categories of higher aggregation involve what we consider to be Expenses directly related to teaching and Expenses indirectly related to education. From the specific categories, which are based on information on spending per school, we explore the relationship between spending per student and their performance in the Mathematics exam in Prova Brasil 2013, using a regression analysis. The estimates have shown that the relationship between spending and performance is not homogeneous among the different categories of expenditure, and that specification of models improves as costs are disaggregated. Among the obtained results, we highlight the indication of a positive and significant relation between spending on Pedagogical coordination and performance on the mathematics exam.
\end{abstract}

Key-words: spending on education; school performance; spending at the school level; school resources. 


\section{LISTA DE TABELAS}

Tabela 1 - Percentual de despesas correntes e de capital, segundo curso - rede pública estadual, São Paulo, 1968

Tabela 2 - Percentual de despesas por categoria de despesa, segundo as etapas oferecidas pelas escolas - rede pública estadual, São Paulo, 1981

Tabela 3 - Custo total, direto e indireto nos levantamentos de custo-aluno

Tabela 4 - Proposta de indicadores de recursos escolares

Tabela 5 - Proposta de estrutura de gastos escolares

Tabela 6 - Indicadores de recursos escolares para duas escolas norte-americanas

Tabela 7 - Proposta de categorias de gastos para a rede municipal de São Bernardo do Campo

Tabela 8 - Despesa pública municipal com educação - São Bernardo do Campo, 2013

Tabela 9 - Indicadores de contexto da rede municipal de São Bernardo do Campo

Tabela 10 - Escolas excluídas da análise e motivo da exclusão

Tabela 11 - Categorias de gasto consideradas e gastos das escolas - rede municipal de São Bernardo do Campo

Tabela 12 - Categorias de gasto e funções escolares - rede municipal de São Bernardo do Campo

Tabela 13 - Gasto por escola segundo as categorias de gasto consideradas - rede municipal de São Bernardo do Campo

Tabela 14 - Gasto por aluno, segundo nível socioeconômico

Tabela 15 - Gasto anual total com educação especial (salários) e número de alunos de educação especial, por escola

Tabela 16 - Resultados regressão - variável depende: log gasto total com educação especial

Tabela 17 - Correlação entre gastos, desempenho médio das escolas em matemática e outras variáveis de interesse

Tabela 18 - Gastos por aluno das escolas com maiores e menores notas na Prova Brasil, segundo o quartil de nível socioeconômico

Tabela 19 - Proporção do gasto por aluno das escolas com maiores e menores notas na Prova Brasil, segundo o quartil de nível socioeconômico 
Tabela 20 - Resultados regressão A - variável dependente: nota em matemática na Prova Brasil de 2013

Tabela 21 - Resultados regressão B - variável dependente: nota em matemática na Prova Brasil de 2013 


\section{LISTA DE GRÁFICOS}

Gráfico 1 - Desempenho em língua portuguesa e nível socioeconômico - escolas da rede municipal de São Bernardo do Campo

Gráfico 2 - Desempenho em matemática e nível socioeconômico - escolas da rede municipal de São Bernardo do Campo

Gráfico 3 - Distribuição das escolas segundo o gasto total por aluno - rede municipal de São Bernardo do Campo

Gráfico 4 - Distribuição das escolas segundo o Indicador de nível socioeconômico - rede municipal de São Bernardo do Campo

Gráfico 5 - INSE e medidas de disponibilidade de recursos escolares - Gasto total por aluno

Gráfico 6 - INSE e medidas de disponibilidade de recursos escolares - Gasto diretamente relacionado ao ensino

Gráfico 7 - INSE e medidas de disponibilidade de recursos escolares - Gasto com currículo básico

Gráfico 8 - INSE e medidas de disponibilidade de recursos escolares - Gasto com gestão escolar

Gráfico 9 - INSE e medidas de disponibilidade de recursos escolares - Gasto com orientação e suporte às atividades de ensino e aprendizagem

Gráfico 10 - INSE e medidas de disponibilidade de recursos escolares - Gasto com espaço para pesquisa, leitura e ensino

Gráfico 11 - INSE e medidas de disponibilidade de recursos escolares - Professores com nível superior

Gráfico 12 - INSE e medidas de disponibilidade de recursos escolares - Aluno-turma

Gráfico 13 - Distribuição das escolas segundo a nota em matemática na Prova Brasil de 2013 - rede municipal de São Bernardo do Campo 


\section{SUMÁRIO}

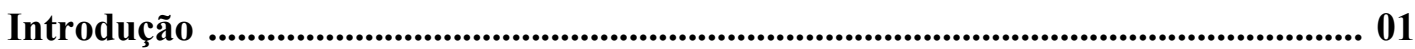

1. Gastos das escolas, despesa pública com educação e o desempenho escolar: a informação que temos produzido, seus usos e as conclusões possíveis .................. 09

1.1. A informação de gasto no nível da escola no Brasil ..................................... 09

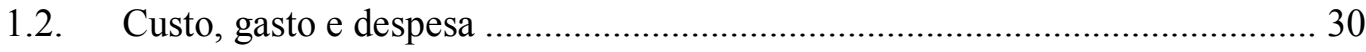

1.3. Gastos educacionais e desempenho escolar no Brasil .................................. 34

2. Gastos no nível da escola e desempenho: abordagens e considerações baseadas no contexto norte-americano ............................................................................................ 41

3. Gastos e desempenho escolar na rede municipal de São Bernardo do Campo: uma análise no nível da escola .............................................................................65

3.1. Proposta de classificação dos gastos escolares para a rede municipal de ensino de São Bernardo do Campo ............................................................................ 65

3.2. A rede municipal de ensino de São Bernardo do Campo ................................ 70

3.3. Os gastos das escolas da rede municipal de ensino de São Bernardo do Campo 75

3.3.1. A construção da informação de gasto no nível da escola ......................... 78

3.4. Os gastos por escola e o nível socioeconômico dos alunos ............................ 83

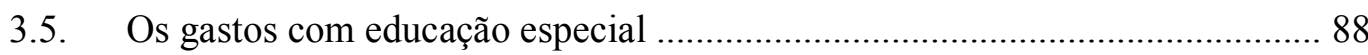

3.6. Gastos por aluno e desempenho ..................................................................... 91

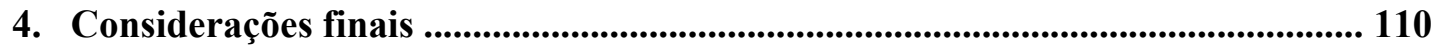

Referências ..................................................................................................................................... 114

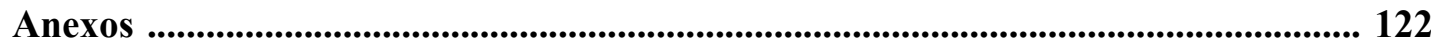




\section{Introdução}

Seja quando entendidos como essenciais para a viabilização de um bem social percebido como necessário, seja como condição necessária para a garantia de um direito, seja ainda quando considerados como um investimento, os recursos destinados à educação parecem constituir um meio que se justifica diante do fim para o qual aponta, ainda que meio e fim possam adquirir muitos significados.

O debate acerca da alocação de recursos à educação tem despertado o interesse de pesquisadores de diferentes áreas do conhecimento. As múltiplas representações de educação e de escola e a existência de múltiplos interesses tem contribuído para que a produção do conhecimento sobre o assunto seja bastante diversificada, contando com a participação de educadores, economistas, administradores etc. Se, por um lado, a posição de fronteira ocupada pelo tema torna fértil sua participação no campo científico, por outro, ao que parece, tem tornado menos provável a obtenção de consensos.

Dentre os dissensos existentes, destaca-se o que emerge do debate acerca da existência ou não de determinados efeitos dos recursos destinados à manutenção das atividades escolares sobre o desempenho dos alunos. Tal debate veio à tona em meados da década de 1960, com a publicação do que ficou conhecido como Relatório Coleman (COLEMAN et al, 1966), que apontou ser o nível socioeconômico dos alunos o principal fator associado ao seu desempenho, sendo pouco relevantes os fatores correspondentes aos recursos presentes nas escolas. A conclusão de que os recursos não importam, motivação de inúmeras pesquisas e debates, tem potencial para impactar de forma significativa a realidade de escolas e sistemas educativos, ao contribuir para a sustentação de decisões que impliquem em restrição do financiamento educacional.

O tipo de análise empreendida por Coleman baseia-se no uso de funções de produção, que são modelagens destinadas a identificar possibilidades de relação entre determinados insumos e os resultados ou produtos correspondentes (PICUS, 1995, p. 25). Amparada na teoria microeconômica, a função de produção de educação em questão estabelece uma relação entre o resultado eleito como desejado - o desempenho do aluno - e diversas variáveis mensuráveis que possam explicar tal desempenho (WALTENBERG, 2006, p. 122). Assim, sustentada por 
um aparato estatístico que tem se sofisticado no decorrer do tempo, a mensuração da relação entre o desempenho de alunos e variáveis relacionadas aos alunos e às escolas que estes frequentam tem sido empreendida em diversos contextos educacionais, incluindo o brasileiro.

Entre os pesquisadores dedicados ao exame da existência ou não de relação entre os recursos destinados à educação e o desempenho dos alunos, Eric Hanushek tem ocupado lugar de destaque. Chama a atenção o título do primeiro de seus levantamentos bibliográficos, que procura registrar as principais conclusões das pesquisas que tratam do tema em questão: “Throwing Money at Schools". O artigo, publicado pelo economista em 1981, aponta que as evidências disponíveis indicam não haver relação entre gastos e desempenho dos alunos, sendo provavelmente inócuas, para o fim delimitado, medidas como a redução de classes ou a contratação de professores submetidos a treinamentos (HANUSHEK, 1981).

A conclusão dos trabalhos do autor não tem variado no tempo. Nos diversos levantamentos de pesquisas sobre o tema, a constatação é a de que não há relação consistente e sistemática entre gastos e desempenho dos alunos, sendo isto válido quando os gastos são considerados de forma agregada (recursos financeiros) ou quando são expressos na forma de recursos presentes nas escolas (HANUSHEK, 1986, 1989, 1994, 1997, 2003). Importante ressalva, porém, é feita, no sentido de relativizar a conclusão recorrente:

Uma ampla gama de análises indica que, em geral, as políticas de recursos não levam a melhorias perceptíveis no desempenho dos estudantes. É importante entender o que se pode e o que não se pode entender a partir desta conclusão. Primeiro, isso não quer dizer que dinheiro e recursos nunca importam. Claramente há situações em que turmas pequenas ou recursos adicionais têm impacto. É justamente porque não há disponibilidade de descrições claras de quando e onde essas situações ocorrem, que as políticas de alocação de recursos, como as realizadas pelos governos centrais, podem acertar em alguns casos e errar em outros, o que geralmente leva a resultados contraditórios [que se anulam no agregado]. (HANUSHEK, 2003, p. 89, grifo do autor, tradução nossa) ${ }^{1}$

\footnotetext{
${ }^{1}$ Original: "A wide range of analyses indicate that overall resource policies have not led to discernible improvements in student performance. It is important to understand what is and is not implied by this conclusion. First, it does not mean that money and resources never matter. There clearly are situations where small classes or added resources have an impact. It is just that no good description of when and where these situations occur is available, so that broad resource policies such as those legislated from central governments may hit some good uses but also hit bad uses that generally lead to offsetting outcomes" (HANUSHEK, 2003, p. 89 , grifo do autor).
} 
A ressalva acima transcrita parece sugerir que a importância dos recursos destinados às escolas pode variar segundo o contexto e de acordo com os usos destes. O autor, porém, não explora em que situações um acréscimo de recursos pode fazer a diferença no desempenho dos alunos, sugerindo apenas que a adoção de incentivos - como remuneração variável para professores em função do desempenho dos alunos - pode contribuir para o alcance da melhoria que se deseja (p. 93).

Pertinente debate acerca da relevância ou não dos recursos foi travado entre Hanushek e Hedges, Laine e Greenwald (1994). A partir do exame dos mesmos estudos que serviram de base para as conclusões de Hanushek (1989), os autores contestam os achados deste. Empreendendo método de análise diferente do adotado no trabalho que contestam, os pesquisadores apontam que a evidência obtida permite afirmar que há relação entre recursos destinados às escolas e o desempenho dos alunos, sobretudo quando tais recursos são considerados na forma de gastos por aluno (HEDGES, LAINE e GREENWALD, 1994).

A contestação implicou em tréplica de Hanushek, que aponta as fragilidades do trabalho dos autores e sugere que a sofisticação metodológica utilizada na análise que contesta seus achados não equivale a rigor metodológico, sendo este último o ponto fraco do trabalho de Hedges, Laine e Greenwald. Assim, o autor mantém a conclusão de que a variação de gastos ou de recursos presentes nas escolas não explica a variação do desempenho dos alunos (HANUSHEK, 1994).

Vignoles et al (2000) empreendem ampla revisão da literatura baseada em análises de funções de produção em educação, a qual inclui levantamento bibliográfico das revisões da literatura empreendidas até então. Ainda que não coloque um ponto final no debate, o trabalho aponta algumas das causas da multiplicidade de resultados e conclusões acerca do tema. Dentre elas, destacam-se as variações de metodologias empregadas para a estimação das relações entre desempenho dos alunos e os fatores associados a tal desempenho e a má especificação de modelos, sendo comum a presença de viés causado por variáveis omitidas (p. 8).

No Brasil, os estudos que exploram a relação entre desempenho e fatores associados têm apontado para efeitos positivos dos recursos presentes nas escolas sobre o desempenho dos alunos, sobretudo no que diz respeito à infraestrutura disponível (FERRÃO et al, 2001; 
SOARES, 2004; FRANCO et al, 2007; ALVES e SOARES, 2013). Para a produção da informação que viabiliza tais estudos, têm sido utilizados, quase sempre, os resultados dos alunos em testes de larga escala e os dados provenientes da aplicação de questionários contextuais, sendo o Sistema Nacional de Avaliação da Educação Básica - SAEB a fonte de informação para a maior parte dos estudos produzidos até o momento.

Em relação a outros fatores que estão relacionados a variações nos gastos das escolas, como salários de professores, período de aulas e tamanho de turmas, os resultados são menos consensuais. Albernaz, Ferreira e Franco (2002), com base nos dados do SAEB de 1999, indicam ser o salário do professor relevante para explicar o desempenho dos alunos (p. 19). Resultado oposto é obtido por Menezes-Filho (2007), que não encontra relação entre o salário de professores e proficiência, considerando os dados da rede pública do SAEB de 2003. Ferrão et al (2001), com base nos dados do SAEB de 1999, apontam para a inexistência de diferença de desempenho entre alunos que estudam em turno integral e os que frequentam a escola em turno parcial (p. 122), enquanto Franco (2008), utilizando um painel de dados do SAEB, obtém efeitos positivos de turnos superiores a 5 horas sobre o desempenho dos alunos, restando o aumento do período de aulas como recomendação de política educacional (p. 57). Em relação ao tamanho de turmas, é recorrente o apontamento de que não há, no contexto brasileiro, relação entre tal medida e o desempenho dos alunos (BIONDI e FELÍCIO, 2007; CAMARGO e PORTO JÚNIOR, 2014).

São poucos, no Brasil, os estudos que exploram a relação direta entre gastos com educação e o desempenho dos alunos. Um dos motivos da ausência de trabalhos do tipo pode ser a dificuldade de produção de informação sobre gastos em agregação inferior ao nível municipal, fato que torna os coeficientes estimados sujeitos a críticas, como por exemplo a relativa ao viés de agregação (HANUSHEK, RIVKIN e TAYLOR, 1996; FERTIG e WRIGHT, 2004). Em um dos poucos estudos existentes, Amaral e Menezes-Filho (2009) exploram a relação entre gastos por aluno e desempenho, considerando os resultados de escolas municipais na Prova Brasil. A conclusão, baseada em dados agregados por município, aponta para efeitos pouco relevantes ou estatisticamente insignificantes dos gastos sobre o desempenho dos alunos (p. 12). 
Posto o debate, destacamos as ressalvas apresentadas por cada um dos lados. Enquanto Hanushek (2003), conforme já citado, sugere que os recursos podem fazer a diferença, a depender do uso dado a estes, Alves e Franco (2008) ressaltam que “(...) a pura e simples existência dos recursos escolares não é condição para que os recursos façam a diferença: fazse necessário que eles sejam efetivamente usados de modo coerente no âmbito da escola" (p. 494). Ao que tudo indica, portanto, o princípio explicativo da relação entre desempenho e recursos encontra-se principalmente nas opções feitas acerca da alocação e do uso destes.

Esta é a linha de raciocínio adotada por Picus (1995) que, diante da questão aparentemente insolúvel, que dá título a um de seus trabalhos - Does Money Matter in Education? -, sugere o deslocamento do debate de "se os recursos importam" para "como os recursos importam" (p. 30). Neste sentido, o autor indica como abordagem promissora de pesquisa a que estabeleça comparações acerca da alocação e do uso dos recursos entre escolas em que os estudantes apresentem diferentes padrões de desempenho: "Portanto, saber se escolas com alto desempenho utilizam ou não recursos de maneira diferente das outras escolas seria muito útil para a resolução do debate sobre se os recursos importam ou não [para o desempenho dos alunos]" (p. 29, tradução nossa) ${ }^{2}$.

Oliveira (2006) indica a pertinência de abordagem similar. Ao elencar possibilidades de pesquisas a serem empreendidas sobre o financiamento da educação pública no Brasil, o autor aponta como necessárias, dentre outras, as "que realizam algum tipo de correlação entre financiamento e produto" (p. 20-23). Este tipo de trabalho, raro no Brasil, seria caracterizado por:

(...) procurar valorar as diferentes opções de financiamento com relação à consecução de fins educacionais específicos. Por exemplo, qual o resultado de se gastar $\mathrm{x}$ reais em salários de professores ou infraestrutura do ponto de vista do aprendizado dos alunos, ou da permanência dos alunos na escola? (p. 22)

Para o desenvolvimento de pesquisas que explorem a relação entre as diferentes formas de alocação e uso dos recursos destinados às escolas e o desempenho dos alunos, Picus (2000) aponta como necessária a produção de informação sobre os gastos escolares de forma

\footnotetext{
2 Original: "Therefore, knowing whether or not high performing schools utilize resources differently than other
} schools would be very helpful in resolving the debate over whether or not money matters" (Picus, 1995, p. 29). 
desagregada, isto é, no nível da escola e, se possível, no nível do aluno, sendo essencial o estabelecimento de categorias que indiquem não somente os grupos de despesa a que pertencem determinados recursos, mas que apontem para as finalidades às quais os recursos estão associados. Picus explicita a dificuldade e o alto custo de se produzir este tipo de informação, sendo possível que, a depender da escala que se pretenda atingir, o custo seja maior do que o valor que tal informação terá condições de gerar (p. 79). De toda forma, a informação detalhada acerca do recurso que entra nas escolas e do destino dado a ele (em que se transforma, em que medida e para quais fins) é apontada como relevante para o entendimento de como os recursos podem ou não fazer a diferença no âmbito escolar (PICUS e PETERNICK, 1998).

Outra dificuldade a ser enfrentada neste tipo de trabalho relaciona-se ao resultado a ser considerado. Em primeiro lugar, a definição do que seriam resultados desejáveis da educação escolar está sujeita às representações de educação daqueles que propõem tal definição. Em segundo lugar, os resultados que se pode elencar, possivelmente, não estarão estritamente relacionados ao que se passa na escola. Em terceiro lugar, ainda que o aprendizado dos alunos possa ser entendido como resultado a ser observado, a captação deste por meio do desempenho dos alunos em testes de larga escala merece ressalvas. Por fim, a consideração do desempenho dos alunos como referência para a exploração de elementos que possam explicálo pode conduzir a conclusões e recomendações que devem ser avaliadas com cautela, já que medidas que elevem o desempenho dos alunos podem contrariar o que seria desejável do ponto de vista de outros resultados esperados da educação escolar.

De toda forma, entendida a produção de informação sobre o desempenho dos alunos em testes de larga escala como válida para a realização de estudos que viabilizem diagnósticos e prognósticos que contribuam para a melhoria da qualidade do ensino e da aprendizagem, a utilização de tal medida como resultado a ser observado e a exploração de associações possíveis entre o desempenho dos alunos e os recursos destinados às escolas parece ser justificável, desde que a leitura dos achados de pesquisa seja feita com parcimônia e que o pesquisador seja sensível ao reconhecimento das disposições e representações que o acompanham no decurso de seu trabalho. 
Em linha com os trabalhos que, a partir da informação sobre gastos no nível da escola, procuram entender como os recursos podem contribuir para a melhoria dos resultados escolares, esta pesquisa tem como principal objetivo explorar a relação entre os gastos escolares e o desempenho dos alunos, tomando como referência não somente a quantidade de recursos disponibilizada, mas também diferentes possibilidades de alocação destes. A hipótese subjacente a tal objetivo é a de que os recursos podem fazer a diferença no aprendizado dos alunos. Assim, a partir da investigação proposta, espera-se contribuir para a produção do conhecimento acerca de como os recursos destinados às escolas podem ser úteis para a garantia de educação de qualidade para todos.

Além do objetivo exposto, este trabalho apresenta proposta de classificação dos gastos escolares que vincula o financiamento das escolas à finalidade dos recursos viabilizados via financiamento, o que pode contribuir para a avaliação de opções de financiamento segundo lógicas não restritas às classificações econômicas da despesa. O estabelecimento de tal vínculo pode ser útil para a análise de como financiamento, alocação dos recursos e resultados estão relacionados no nível escola (KIMBALL, 2009, p. 48).

Por fim, o levantamento de informações sobre os gastos escolares, empreendido em unidades de ensino de uma rede de médio porte, permitirá a verificação da existência ou não de diferenças nos gastos por aluno entre escolas pertencentes a uma mesma rede de ensino, o que pode contribuir para a reflexão sobre os critérios de alocação de recursos às escolas.

Este trabalho está organizado em cinco partes, incluindo esta introdução. Inicialmente serão abordados os textos que se dedicam à mensuração e análise do custo de implantação e manutenção de escolas públicas no contexto brasileiro. A revisão empreendida teve como focos: 1) identificar características da construção da informação de custo ou de gastos, no nível das escolas, que fossem relevantes para a parte empírica desta pesquisa; 2) verificar em que medida os trabalhos considerados se aproximam ou se distanciam de associar as informações relativas aos recursos escolares a aspectos dos resultados dos alunos, em termos de aprendizagem e 3) identificar diferenças entre as informações de gasto ou despesa pública com educação e custos. Além desta diferenciação, são apontadas algumas das restrições do uso da despesa pública com educação, geralmente considerada no nível municipal, para a exploração da relação entre gastos e desempenho dos alunos. Ainda neste capítulo, é abordada 
brevemente a literatura brasileira que trata da relação entre gastos educacionais e desempenho escolar. O segundo capítulo consiste na revisão de trabalhos produzidos no contexto norteamericano que tratam da alocação e uso dos recursos escolares, tendo em vista a melhoria da aprendizagem dos alunos. Nesta seção serão apresentadas propostas de agregação dos gastos escolares que possam ser úteis para o avanço na compreensão da relação entre gastos e desempenho. No terceiro capítulo, exploramos a relação entre os gastos escolares e o desempenho dos alunos de uma rede municipal de médio porte da região metropolitana de São Paulo. Primeiramente, os dados de gasto obtidos, referentes aos salários dos profissionais que atuam nas escolas da rede em questão, são agregados segundo categorias que dialogam com funções ou atividades desempenhadas pelas escolas. Após a descrição e análise dos dados, testa-se a hipótese de relação entre os gastos, de acordo com as categorias propostas, e o desempenho dos alunos em matemática na Prova Brasil, por meio da estimação de regressões. Por fim, são apresentadas as conclusões. 


\section{Gastos das escolas, despesa pública com educação e o desempenho escolar: a informação que temos produzido, seus usos e as conclusões possíveis}

Este capítulo se dedica a explorar a literatura brasileira que trata de gastos escolares, mensurados a partir de unidades de ensino, e do caminho que estas pesquisas percorrem no tempo, em termos dos usos dados à informação de gastos escolares ou, mais precisamente, à informação de custo-aluno. A partir disso, serão apontadas algumas das vantagens do uso de dados de custo ou de gastos no nível das escolas, relativamente ao uso de informações de despesas públicas com educação, quando se tem por objetivo a análise da relação entre gastos educacionais e resultados da educação escolar.

Além disso, será feita uma breve revisão dos trabalhos que estimam uma relação entre gastos educacionais e desempenho dos alunos, no Brasil. A análise das pesquisas que tratam do custo-aluno no contexto brasileiro será útil para a construção da informação de gastos escolares, a ser empreendida adiante, e a análise da literatura dedicada a estimar a relação entre gastos e desempenho, a partir de dados agregados da despesa pública municipal com educação, será pertinente para que sejam identificadas possibilidades de avanço neste tipo de abordagem, assim como para o embasamento metodológico da análise quantitativa a ser empreendida no terceiro capítulo dessa dissertação.

\subsection{A informação de gasto no nível da escola no Brasil}

Ao que tudo indica, foram os economistas os primeiros a se interessarem pelo estudo dos gastos realizados com educação, estando tal interesse inserido no contexto de trabalhos destinados à análise das taxas de retorno econômico da educação. Em geral, as pesquisas do tipo estimam o custo da educação e, em seguida, o benefício, em termos de salários ou de crescimento econômico, associado a tal custo, o que possibilita o cálculo da taxa de retorno da educação que, neste caso, é considerada um investimento em capital humano. A concepção da educação como um investimento em capital humano remonta a Schultz (1960) e Becker (1962), ainda que indícios deste tipo de abordagem possam ser encontrados já em Marshall (1920) e em "A Riqueza das Nações", de Adam Smith (SMITH, 1996, p. 290), originalmente publicado no final do século XVIII. 
Ao tratar dos custos da educação, Schultz (1967) propõe que sejam considerados não somente os desembolsos realizados pelas famílias e governos para o financiamento das atividades escolares, mas também os salários não-recebidos pelos alunos, sendo estes referentes à remuneração que os alunos deixam de receber por estarem dedicando seu tempo aos estudos e não ao trabalho. A consideração desta parcela dos custos educacionais é apontada como essencial para que a taxa de retorno da educação não seja superestimada (p. 21).

Neste contexto de pesquisas que procuram estimar a taxa de retorno da educação, Levy, Campino e Nunes (1970) produziram o primeiro trabalho que, no Brasil, deu especial atenção ao que tem sido chamado de custo da educação. O trabalho é dedicado à análise da taxa de retorno da educação no contexto do Estado de São Paulo, tendo em vista que o conhecimento de tal taxa contribuiria para a “(...) determinação de uma alocação ótima de recursos para a educação em geral, e, particularmente, dentro do setor educacional"' (p. 3). Os autores, porém, reconhecem os limites e restrições de tal abordagem, salientando que "a análise de taxa de retorno pode ser útil quando empregada em conjunção com outras técnicas e quando as indicações que ela dá são interpretadas adequadamente" (p. 7). Ainda que o trabalho considere as redes pública e privada e que se dedique à análise de despesas agregadas do sistema educacional paulista, não produzindo informações a partir das unidades de ensino, ele constitui importante referência no que diz respeito ao estudo dos gastos com educação no contexto brasileiro.

O quarto capítulo do referido trabalho dedica-se a apresentar metodologia para o cálculo dos custos sociais diretos do sistema educacional do Estado de São Paulo. Os autores definem custos sociais como "aqueles custos incorridos pela coletividade na manutenção e expansão do processo educacional", distinguindo-os dos custos privados, que seriam os suportados pelos estudantes e suas famílias (p. 118). Além desta distinção, os custos sociais são classificados em diretos e indiretos, sendo os primeiros correspondentes às despesas correntes e de capital em que incorrem governos e entidades privadas para a viabilização de serviços educacionais e os últimos representados pelos salários não-recebidos pelos estudantes enquanto se dedicam aos estudos. Tais salários não-recebidos seriam uma aproximação da 
produção sacrificada pela comunidade, sob a suposição de que a produtividade marginal ${ }^{3}$ do trabalho corresponda ao salário não-recebido (p. 118-123).

Tendo em vista as classificações propostas, os autores se dedicam a estimar os custos sociais diretos do ensino no Estado de São Paulo, incluindo na análise a rede pública estadual, a rede privada (a partir de uma amostra de instituições de ensino) e também universidades. De especial interesse são as considerações acerca das estimativas de gastos por aluno da rede pública de educação básica, pois tratam de nível e rede de ensino de interesse nesta dissertação.

A informação produzida sobre os gastos da rede estadual teve como fonte, essencialmente, o conjunto de demonstrações contábeis da Secretaria de Educação, sendo as despesas dispostas segundo a classificação econômica da despesa orçamentária pública, o que consistiu na divisão das despesas entre correntes e de capital (p. 125). Tais despesas foram distribuídas segundo os diferentes cursos, conforme classificação em vigor à época (Tabela 1). Em relação ao universo considerado, foram levadas em conta as despesas com educação de toda a Secretaria, isto é, foram incluídas as despesas que ocorrem fora do âmbito das unidades de ensino, como por exemplo, aquelas realizadas pelo Gabinete do Secretário e por Diretorias de Ensino (p. 130).

Para o cálculo do custo médio por aluno, os autores consideraram a soma das despesas correntes com o custo de capital e o total de alunos matriculados em cada curso. Em relação ao custo de capital, destacam-se duas características relevantes quanto a sua estimativa. Em primeiro lugar, apontando serem as despesas de capital irregulares no tempo e pouco representativas do investimento feito ao longo dos anos, os autores optam por não considerálas no cômputo do estoque de capital. Este estoque, por sua vez, representado pelos valores de prédios e construções, equipamentos e terrenos, é estimado com base no valor dos primeiros, considerando a escassez de informações acerca de equipamentos e terrenos. Assim, o estoque de capital foi determinado a partir do valor de prédios e construções, com base em determinada distribuição percentual esperada para os componentes de tal estoque. A segunda característica a ser ressaltada é a consideração do custo de oportunidade como componente do custo de capital, sendo tal abordagem típica em estudos com viés econômico. Tal custo,

\footnotetext{
${ }^{3}$ A produtividade marginal do trabalho corresponde ao acréscimo, em termos de produto, relacionado à adição de uma unidade de trabalho, em um contexto de produção em que o trabalho é um dos fatores de produção.
} 
referente ao valor do uso alternativo que poderia ser dado ao capital imobilizado nas escolas, somado à depreciação do estoque de capital, constitui o custo de capital considerado (p. 133136).

TABELA 1 - PERCENTUAL DE DESPESAS CORRENTES E DE CAPITAL, SEGUNDO CURSO - REDE PÚBLICA ESTADUAL DE SÃO PAULO, 1968

\begin{tabular}{l|cc}
\hline \multicolumn{1}{c|}{ Cursos } & Despesa Corrente & Despesa de Capital \\
\hline Primário & $93,84 \%$ & $6,16 \%$ \\
Secundário & $94,17 \%$ & $5,83 \%$ \\
Industrial & $93,08 \%$ & $6,92 \%$ \\
Agrícola & $89,55 \%$ & $10,45 \%$ \\
Médio em Geral & $93,78 \%$ & $6,22 \%$ \\
Normal & $92,57 \%$ & $7,43 \%$ \\
\hline
\end{tabular}

Fonte: LEVY, CAMPINO e NUNES, 1970, p. 191. Elaboração própria.

Como é possível perceber, o custo ${ }^{4}$ por aluno concentra-se nas despesas correntes da rede estadual de São Paulo, qualquer que seja a etapa ou modalidade de ensino considerada. Ainda que não tenham sido explicitadas as despesas com pessoal, os autores apontam que estas correspondem a grande parte das despesas correntes (p. 151), resultado que está em linha com as pesquisas posteriores, que se dedicam a estabelecer o gasto por aluno a partir de informações no nível escola.

A primeira, e talvez uma das mais rigorosas pesquisas que empreende análise acerca dos gastos escolares a partir de dados produzidos no âmbito de unidades de ensino, foi realizada por Castro, Assis e Oliveira (1972). Dedicado à estimação dos custos sociais da educação técnica, o trabalho, também inserido no contexto de análise custo-benefício da educação (p. 26), apresenta motivação relacionada à busca por eficiência nos gastos com ensino, sem que tal busca implique em diminuição da qualidade.

(...) a análise dos custos da educação nos permite identificar não somente os desperdícios óbvios e as irregularidades administrativas, mas também as áreas em que seria possível reduzir os dispêndios sem reflexos negativos na

\footnotetext{
${ }^{4}$ Neste ponto do texto já fica clara a dificuldade estabelecida em torno dos termos custo, gasto e despesa, dificuldade que está presente em praticamente todos os trabalhos produzidos sobre o tema. Tal aspecto será tratado adiante, em seção própria.
} 
qualidade da educação oferecida pela escola. É exatamente este tipo de análise que tentaremos realizar na parte final deste trabalho. (p. 27)

Procurando atentar para as peculiaridades de uma análise de custos em escolas que oferecem cursos técnicos, os autores identificam como unidade de medida a ser mensurada o custoaluno-hora, sendo esta útil para a comparação de custos entre cursos com diferentes períodos de duração (p. 36). Em relação aos resultados, considerando que tratam de tema específico custos no âmbito do ensino técnico -, restringimo-nos a apontar que, em relação ao padrão de gastos do ensino regular, os custos estimados na pesquisa parecem apontar para maior participação dos custos de capital, o que era esperado, dada a especificidade dos cursos.

A despeito da particularidade da análise empreendida, importantes considerações são feitas a respeito do tratamento a ser dado à depreciação de prédios e equipamentos. Em relação ao tema, os autores sugerem a fragilidade da consideração de taxas de depreciação padronizadas, que tomam como base ambientes fabris e/ou empresariais, para o cálculo da depreciação em instituições de ensino, em que o uso dos espaços e equipamentos tem características bastante específicas (p. 48). No que diz respeito à estimativa da depreciação, a abordagem seguida foi a de considerá-la igual a zero. Tal opção teve como base a realização de simulações que apontavam para a pouca diferença, no cálculo do custo de capital, entre a consideração de determinada vida útil para prédios e equipamentos e de vida útil infinita para os mesmos ( $p$. 53-57). Desta forma, o custo de capital restringiu-se, no estudo em questão, à consideração do custo de oportunidade e dos gastos com manutenção.

Os dois trabalhos citados constituem importante marco no que diz respeito ao estudo dos gastos com educação no Brasil, tendo contribuído inclusive para a difusão de abordagens metodológicas consistentes e coerentes com as bases teóricas que as sustentam. Em relação à motivação destes trabalhos, que remonta à análise do retorno econômico da educação, parece possível sugerir que esta tende a perder força em contextos em que a educação passe a constituir um direito, devendo ser garantida independentemente do retorno econômico a que possa estar associada (BROOKE e AFONSECA, 1991). Além disso, a existência da obrigatoriedade da educação, ao menos no que diz respeito à educação básica, tenderia a deixar sem base para estimativas os estudos que se propusessem a mensurar o custo dos salários-não-recebidos pelos alunos deste nível do ensino. De toda forma, em relação ao 
ensino técnico, a depender dos objetivos associados à sua oferta, o tipo de análise em questão pode se mostrar pertinente.

Ainda em relação à abordagem dos custos da educação presentes nos trabalhos citados até aqui, vale destacar que esta está amparada em uma concepção de escola e de educação próprias da economia, o que explica o foco em questões sobre a eficiência na alocação dos recursos, com a busca pela composição de fatores que conduza ao melhor resultado. Isto é, a modelagem típica da microeconomia, que busca a combinação de fatores de produção que minimize os custos, considerada uma dada tecnologia de produção, é transposta, ainda que não sem ressalvas, para a educação.

Para que a análise econômica possa ser aplicada ao setor educacional necessário se torna que este seja entendido como uma unidade econômica integrada, dentro das categorias econômicas usuais. Assim, supõe-se que, dentro de um sistema econômico, a escola possui as características básicas de uma unidade de produção, que oferece serviços educacionais com a utilização de fatores de produção tais como professores, alunos, instalações físicas, etc., dentro de um dado nível tecnológico. Idealmente pois interessa obter o custo realizado do fluxo de serviços prestados por professores, bibliotecários, administradores, dos custos de manutenção e operação da escola (despesas correntes) e de parcelas referentes à depreciação e custo de oportunidade (taxa implícita de juros) do estoque de capital (despesas de capital). (LEVY, CAMPINO e NUNES, 1970, p. 119)

Aproximadamente uma década após o trabalho de Castro, Assis e Oliveira (1972), Vitor Henrique Paro (1981) empreende pesquisa de grande porte acerca dos custos educacionais no âmbito nacional, tendo como foco as escolas de ensino fundamental e médio da rede estadual paulista. Ao que parece, este é o primeiro trabalho publicado, sobre o tema, elaborado por um autor ligado ao campo da educação no Brasil.

O estudo, concebido no contexto da Secretaria da Educação do Estado de São Paulo, tem objetivos relacionados à eficiência na alocação e no uso dos recursos orçamentários (p. 9), ainda que na prática a pesquisa talvez tenha ultrapassado este foco, sobretudo ao tratar do custo-aluno segundo as "classes de renda per capita" e segundo os "níveis de carência" (p. 76-82). O trabalho teve como base uma amostra de 66 escolas, distribuídas segundo as regiões do Estado (São Paulo, Grande São Paulo e Interior) e segundo outras características populacionais de interesse. 
Paro distancia-se em boa medida dos trabalhos anteriormente citados. Em primeiro lugar, não são considerados os gastos efetuados pela administração do sistema, sendo consideradas apenas as despesas efetuadas no âmbito das unidades escolares (p. 13). Em segundo lugar, o autor não considera, no cômputo do custo por aluno, os custos de oportunidade, apontando inadequações na consideração de tais custos para efeitos de mensuração dos custos da educação (p.15). Por fim, são consideradas, além das despesas correntes e de capital, despesas classificadas como sociais, sendo estas relativas aos gastos com "assistência nutricional, assistência médica e assistência odontológica" dos alunos (p. 20). Tais despesas não foram consideradas nos estudos anteriormente citados, sub a justificativa de não serem despesas com educação. Isto é, elas seriam realizadas em outros lugares que não a escola, caso esta não oferecesse tais serviços (LEVY, CAMPINO e NUNES, p. 120; CASTRO, ASSIS e OLIVEIRA, 1972, p. 34). Ainda que Paro concorde que estas despesas não devam ser classificadas como relativas à educação, opta por considerá-las, separando-as em categoria própria (p. 19-21).

Ao destacar, dentre as despesas correntes e de capital, as despesas entendidas como sociais, o autor estabelece classificação que foge à tradicionalmente adotada, restrita à divisão econômica da despesa pública, criando categoria que aponta mais para a finalidade da despesa realizada do que para os insumos que a viabilizam. Tal prática, incomum nos estudos sobre gastos por aluno no Brasil, parece promissora, ao menos no sentido de estabelecer vínculo entre o financiamento da educação e o destino dado aos recursos no âmbito das escolas.

A mesma tendência de apontar para a finalidade dos recursos pode ser percebida na classificação relativa a equipamentos, que foram agrupados em "equipamentos em geral", "equipamentos dos laboratórios" e "equipamentos das oficinas" e na divisão das despesas com pessoal, classificadas em "pessoal docente em exercício", "pessoal em função técnica" e "pessoal em função administrativa" (p. 16-18).

Para o cálculo do custo médio por aluno, Paro utiliza procedimento diferente do adotado nas pesquisas anteriores, ao defender a consideração do número de alunos aprovados no ano em questão e não do número de alunos matriculados. O autor justifica sua abordagem: 
Se tomarmos, como base de cálculo do custo aluno/ano, o total de alunos matriculados, não estaremos calculando com exatidão o custo do produto da "empresa" escola, já que o objetivo desta é a produção de alunos com instrução suficiente para serem aprovados ou promovidos para a próxima série. Ao declarar que uns tantos alunos foram aprovados, enquanto outros não, a própria escola está reconhecendo que atingiu os objetivos mínimos com relação à educação escolar apenas com os primeiros, os quais constituem, assim, seu produto final, considerando os últimos como uma espécie de "sobra" que não pode ser tida como produto acabado. (p. 61)

Considerando que o percentual médio de aprovação das escolas da amostra é de $66,29 \%$, a opção de considerar os alunos aprovados implicou em aumento significativo do custo por aluno em relação ao valor obtido quando considerados os alunos matriculados. Dito isto, pode-se dizer que a opção adotada dificulta, em alguma medida, a comparação do custo por aluno entre as escolas. Isto é, escolas que atenderam a quantidades similares de alunos, necessitando e dispondo de quantidades similares de recursos, podem ter um custo médio diferente, a depender do percentual de aprovação dos alunos, o qual varia consideravelmente na amostra. Desta forma, o resultado esperado é o de que escolas com baixo percentual de aprovação tenham custo por aluno alto e escolas com alto percentual de aprovação tenham custo por aluno baixo, o que pode induzir a conclusões equivocadas acerca da relação entre recursos e resultados.

Em relação aos resultados obtidos, nota-se a predominância de despesas com pessoal, que correspondem a $76 \%$ do total. Dentre estas, assumem maior importância as despesas com docentes, que totalizam quase $60 \%$ do total do custo por aluno. As despesas de capital e as despesas classificadas como sociais têm participação de $18,4 \%$ e 2,85\%, respectivamente, no custo por aluno, consideras todas as escolas da amostra (p. 67). A Tabela 2 traz a distribuição percentual do custo segundo as categorias de despesa, para os tipos de escola presentes na amostra.

Ainda acerca dos resultados, destaca-se a variação do custo por aluno segundo as classes de renda per capita, obtidas a partir da delimitação de regiões da cidade de São Paulo. As escolas localizadas em regiões de maior renda per capita apresentaram maior valor para o custo por aluno, tendendo tal custo a decrescer conforme decresce a renda per capita, sendo considerado o custo por aluno matriculado, neste caso. $\mathrm{O}$ autor sugere que a explicação para tal resultado está relacionado com o maior poder de pressão, por parte da população de alta 
renda, no sentido de influenciar a alocação de recursos públicos em benefício próprio (p. 7679).

TABELA 2 - PERCENTUAL DE DESPESAS POR CATEGORIA DE DESPESA, SEGUNDO AS ETAPAS OFERECIDAS PELAS ESCOLAS - REDE PÚBLICA ESTADUAL DE SÃO PAULO, $1981^{5}$

\begin{tabular}{l|cccccc|ccc|c}
\hline $\begin{array}{c}\text { Tipos de } \\
\text { escola }\end{array}$ & Consumo & Docentes & Técnicos & Adm. & Pessoal & $\begin{array}{c}\text { Desp. } \\
\text { Correntes }\end{array}$ & Aliment. & $\begin{array}{c}\text { Assist. } \\
\text { Odont. }\end{array}$ & $\begin{array}{c}\text { Desp. } \\
\text { Sociais }\end{array}$ & $\begin{array}{c}\text { Desp. } \\
\text { Capital }\end{array}$ \\
\hline $1^{\circ} \grave{a} 4^{\circ}$ série & $2,65 \%$ & $39,87 \%$ & $6,65 \%$ & $20,95 \%$ & $67,47 \%$ & $\mathbf{7 0 , 1 2 \%}$ & $2,63 \%$ & $0,00 \%$ & $\mathbf{2 , 6 3 \%}$ & $\mathbf{2 7 , 2 5 \%}$ \\
$1^{\circ}$ à $8^{\circ}$ série & $2,31 \%$ & $59,90 \%$ & $1,25 \%$ & $16,90 \%$ & $78,06 \%$ & $\mathbf{8 0 , 3 6 \%}$ & $2,89 \%$ & $0,87 \%$ & $\mathbf{3 , 7 6 \%}$ & $\mathbf{1 5 , 8 7 \%}$ \\
$1^{\circ}$ e $2^{\circ}$ graus & $3,16 \%$ & $62,45 \%$ & $1,42 \%$ & $15,22 \%$ & $79,11 \%$ & $\mathbf{8 2 , 2 6 \%}$ & $1,79 \%$ & $0,91 \%$ & $\mathbf{2 , 6 9 \%}$ & $\mathbf{1 5 , 0 4 \%}$ \\
$2^{\circ}$ grau & $3,24 \%$ & $51,35 \%$ & $0,57 \%$ & $17,24 \%$ & $69,15 \%$ & $\mathbf{7 2 , 3 9 \%}$ & $0,10 \%$ & $0,00 \%$ & $\mathbf{0 , 1 0 \%}$ & $\mathbf{2 7 , 5 1 \%}$ \\
CEI & $3,10 \%$ & $50,50 \%$ & $1,20 \%$ & $8,00 \%$ & $59,70 \%$ & $\mathbf{6 2 , 8 0} \%$ & $0,00 \%$ & $0,00 \%$ & $\mathbf{0 , 0 0 \%}$ & $\mathbf{3 7 , 2 0 \%}$ \\
Estado & $2,71 \%$ & $57,63 \%$ & $1,71 \%$ & $16,69 \%$ & $76,04 \%$ & $\mathbf{7 8 , 7 4 \%}$ & $2,17 \%$ & $0,68 \%$ & $\mathbf{2 , 8 5 \%}$ & $\mathbf{1 8 , 4 0 \%}$ \\
\hline
\end{tabular}

Fonte: PARO, 1981, p. 72.

Ainda que o trabalho de Paro tenha estabelecido abordagem de investigação que extrapola as análises de alocação dos recursos focadas em elementos de despesa (relacionados a tipos de insumo), apontando, em alguma medida, para a finalidade do recurso viabilizado via financiamento, não é possível notar a intenção de associação entre recursos e resultados da educação escolar, exercício que poderia ter sido empreendido a partir do estabelecimento de relações entre, por exemplo, o custo por aluno (matriculado) e o percentual de aprovação, observando simultaneamente variáveis como a proporção de alunos segundo o nível de carência e região das escolas.

No final da década de 1980, Xavier e Marques (1988) elaboram estudo acerca do custo direto de funcionamento das escolas públicas de $1^{\circ}$ grau, empreendido em âmbito nacional. $\mathrm{O}$ trabalho, concebido no contexto do Ministério da Educação, tinha como intuito “(...) auxiliar a tomada de decisão e o planejamento educacional (...)", tendo como foco o estabelecimento de medida de custo por aluno que possibilitasse a comparação de custos entre as diferentes regiões do país, o que serviria de subsídio para “(...) uma melhor alocação federal de recursos" (p. 9).

\footnotetext{
${ }^{5}$ Relativamente à tabela original, forma excluídas as colunas que detalhavam os percentuais de despesas com prédios e equipamentos.
} 
A abordagem seguida, restrita à mensuração dos custos diretos, implicou na consideração apenas dos custos relacionados à unidade escolar, sendo desconsiderados, dentre outros, os associados à manutenção das secretarias de educação e o custo dos salários não recebidos pelos alunos (p.14). Ao que parece, a opção feita relaciona-se com a orientação do Ministério da Educação acerca da simplicidade e do baixo custo que a pesquisa deveria ter (p. 10).

A amostra de escolas foi construída com base em características que guardassem correspondência com possíveis variações nos custos. Assim, foram selecionadas, em cada região do país, escolas municipais e estaduais, urbanas e rurais, localizadas no interior dos estados e nas capitais e ainda escolas de diversos tamanhos, segundo o número de salas de aula (p.19).

A mensuração feita restringiu-se aos custos de funcionamento de cada escola, não sendo considerados custos relativos à instalação desta ou os relacionados à depreciação do prédio escolar (p. 33). As despesas das escolas foram agrupadas segundo categorias comuns ao orçamento público, com exceção do material de consumo, que foi dividido em seis grupos, segundo o uso pretendido para os recursos de cada grupo, e da despesa com pessoal, que foi classificada em despesa com pessoal docente e não docente (p. 15).

Ao analisarem os resultados obtidos para os estados da região sul, os autores instauram abordagem que tende a estabelecer relações entre o financiamento das escolas e aspectos relativos aos resultados dos alunos, a partir de informações sobre gastos das unidades escolares. Partindo do gasto por aluno com docentes e não docentes, os pesquisadores passam a analisar a proporção entre tais gastos, apontando que na região em questão a razão entre despesas com docentes e não docentes é de 3,4. Tal relação, contudo, varia entre os Estados, sendo de 5,2, 8,4 e 2,3 para Paraná, Santa Catarina e Rio Grande do Sul, respectivamente. A baixa razão entre despesas com docentes, em relação aos não docentes, no Rio Grande do Sul, é dada principalmente pelo alto valor da despesa com pessoal não docente neste Estado, o que, somado ao gasto com docente, que também é o maior da região, leva o Rio Grande do Sul a ter gasto com pessoal, por aluno, duas vezes maior que o do Paraná e 1,4 vezes maior que o de Santa Catarina (p. 39). Tais medidas seriam úteis para a avaliação dos diferentes tipos de estratégia na alocação dos recursos, tendo em vista os resultados que poderiam gerar, 
em termos de aprovação ou de da aprendizagem dos alunos. O trabalho em questão, ao que parece, procura fazer este tipo de avaliação:

Esses dados poderiam estar revelando que uma maior quantidade de insumos estaria sendo alocada a cada aluno gaúcho, o que, tudo o mais permanecendo constante, deveria se refletir positivamente no desempenho escolar (registre-se que para os demais componentes do custo/aluno o padrão diferencial de gastos, entre estados, atua no mesmo sentido). Os dados são insuficientes para evidenciar uma influência como a sugerida acima, mas outras estatísticas do sistema educacional, para o $1^{\circ}$ grau, não parecem suportar a conclusão de um desempenho escolar bem mais alto no Rio Grande do Sul do que nas demais UF da região, de modo a justificar as diferenças de custo registradas. Mais provável é que esteja havendo um superdimensionamento do pessoal não docente nas escolas púbicas, sobretudo nas estaduais. (XAVIER e MARQUES, 1988, p. 39)

Ao final do texto, os autores fazem importante ressalva acerca do tipo de informação produzida pelo estudo empreendido, apontando para a necessidade de pesquisas que indicassem não somente o custo por aluno em uma escola representativa da realidade em determinado momento do tempo, mas para o custo por aluno associado a uma escola que contasse com recursos necessários para a oferta de um ensino de qualidade. Assim, ao que parece, os autores apontam para a necessidade do estabelecimento do que futuramente seria conhecido como Custo-Aluno- Qualidade, conforme proposto por Carreira e Pinto (2007).

Os custos apresentados dizem respeito ao que existe na escola e não àquilo que deveria existir. Pode ser que a diferença de custos esteja refletindo diferenças qualitativas, e que a escola mais cara seja, de fato, a mais bem equipada e (consequentemente?) a de melhor ensino. Há necessidade, portanto, de serem efetuados estudos que definam padrões de escola. (XAVIER e MARQUES, 1988, p. 49)

Paralelamente ao estudo dos custos da educação escolar, foram ganhando espaço discussões acerca dos desafios a serem enfrentados para a melhoria da educação pública no país. A Constituição Federal de 1988, sintetiza, em alguma medida, os resultados de tais discussões, tornando concretas propostas que, normatizadas, passam a pautar a atuação dos entes federativos em relação à educação.

A efetivação do dever do Estado para com a educação, entendida na Constituição como direito de todos, passa pela garantia de acesso às diversas etapas e modalidades da educação obrigatória, assim como pela "garantia de padrão de qualidade" do ensino, conforme redação 
do inciso VII do Artigo 206. Com vistas a viabilizar o cumprimento de tais deveres, o Artigo 212 estabelece o percentual mínimo de recursos a ser aplicado anualmente, pelos entes federativos, na manutenção e desenvolvimento do ensino.

Foge ao escopo deste trabalho o exame da emergência da concepção da educação como um direito. Contudo, parece pertinente a consideração de tal concepção para a análise das relações assumidas, na legislação, entre os recursos a serem destinados à educação, qualidade do ensino, a qual deve ser garantida pelo Estado, e a realização do direito à educação no Brasil. Ao que tudo indica, estes temas/enfoques terão grande influência sobre a produção de estudos sobre custos e alocação dos recursos nas escolas, a partir dos anos 2000.

Qualidade do ensino e recursos a serem destinados à educação, que na Constituição Federal não parecem ser necessariamente relacionados ${ }^{6}$, surgem como dois lados de uma mesma moeda na Lei de Diretrizes e Bases da Educação, de 1996. Tal norma instaura o seguinte entendimento acerca da relação entre qualidade do ensino e recursos destinados ao financiamento das escolas:

Art. $4^{\circ} \mathrm{O}$ dever do Estado com educação escolar pública será efetivado mediante a garantia de: (...)

IX - padrões mínimos de qualidade de ensino, definidos como a variedade e quantidade mínimas, por aluno, de insumos indispensáveis ao desenvolvimento do processo de ensino-aprendizagem.

Art. 74. A União, em colaboração com os Estados, o Distrito Federal e os Municípios, estabelecerá padrão mínimo de oportunidades educacionais para o ensino fundamental, baseado no cálculo do custo mínimo por aluno, capaz de assegurar ensino de qualidade.

Parágrafo único. O custo mínimo de que trata este artigo será calculado pela União ao final de cada ano, com validade para o ano subsequente, considerando variações regionais no custo dos insumos e as diversas modalidades de ensino. (BRASIL, 1996)

O inciso IX do Art. 4 aponta para uma definição do que seria, para a lei em questão, a qualidade de ensino que, ao ser garantida, efetiva o dever do Estado com a educação escolar pública. A identificação de qualidade do ensino com variedade e quantidade de insumos, ainda que controversa, revela algo importante. Para a LDB, a não garantia dos recursos significa a não garantia do direito a ensino de qualidade. Isto é, não disponibilizar variedade e

\footnotetext{
${ }^{6}$ A relação entre recursos financeiros e qualidade do ensino, na Constituição Federal, passa a existir com a nova redação dada ao parágrafo primeiro do art. 211 pela Emenda Constitucional nº 14, de 1996.
} 
quantidade mínimas, por aluno, de insumos indispensáveis ao processo de ensinoaprendizagem, significa não assegurar padrões mínimos de qualidade de ensino, incorrendo o Estado, assim, no descumprimento de seu dever com a educação escolar pública.

O Art. 74 traz entendimento um pouco diferente ao tratar da relação entre qualidade e a destinação de recursos financeiros no âmbito do ensino fundamental. Neste artigo, a LBD aponta para os recursos não como a própria qualidade do ensino, mas como capazes de assegurar ensino de qualidade.

Estes dois artigos, portanto, explicitam o vínculo entre recursos financeiros a serem destinados às escolas e o cumprimento do direito à educação, pois ou apontam para tais recursos como indispensáveis para a garantia de ensino de qualidade ou instauram o entendimento de que a qualidade do ensino consubstancia-se nos recursos destinados à educação. Isto é, se o direito à educação só é cumprido em sua integralidade com ensino de qualidade, pode-se dizer que, para a LDB, a destinação de recursos à educação constitui não somente condição para o cumprimento do direito à educação, mas a própria realização deste direito.

É neste contexto de entendimentos acerca da relação entre financiamento das escolas, qualidade do ensino e cumprimento do direito à educação, que se insere a pesquisa denominada "Levantamento do custo-aluno-ano em escolas que oferecem condições para a oferta de um ensino de qualidade", pesquisa esta que, sob coordenação do Instituto Nacional de Estudos e Pesquisas Educacionais Anísio Teixeira - INEP, envolveu a participação de diversos grupos de pesquisadores, nas diferentes regiões do país.

O trabalho, que resultou em uma série de publicações, ao que parece, seguiu o caminho delineado por Xavier e Marques (1988), e procurou dimensionar qual era o custo por aluno em escolas que apresentavam um conjunto de características que apontavam, potencialmente, para um ensino de qualidade. Assim, os recursos presentes nestas escolas seriam, de alguma forma, uma proxy para o dimensionamento dos recursos que deveriam existir em cada escola, segundo as diferentes etapas, modalidades e localidades, para a viabilização de um ensino de qualidade (FARENZENA, 2005, p.12-13; CAMARGO et al, 2006, p. 22). A motivação da pesquisa é bastante diferente da motivação dos trabalhos anteriores: 
Os objetivos comuns às investigações levadas a cabo em cada estado foram: levantar e analisar as fontes de recursos de escolas públicas e os principais componentes do custo-aluno num período de doze meses; levantar e analisar as principais características das escolas, em especial no que se refere à organização e à gestão escolar; subsidiar o Governo Federal e administrações públicas em geral, no estudo das necessidades de financiamento público à educação a partir do custo-aluno apurado nas instituições; avaliar as relações $e$ implicações do custo-aluno nas condições de qualidade do ensino oferecidas pelas escolas. (FARENZENA, 2005, p. 7, grifo nosso)

O estudo, empreendido com base em uma amostra intencional de 95 escolas públicas de educação básica, teve como critério para a seleção das unidades de ensino o Índice de Escolha de Escolas - IEE, índice criado para sintetizar um conjunto de características que estariam relacionadas à oferta de ensino de qualidade nas escolas ${ }^{7}$. A medida em questão foi construída com base nas seguintes dimensões/indicadores:

Infraestrutura: serviços básicos, equipamentos pedagógicos, infraestrutura pedagógica, equipamentos básicos, infraestrutura básica; Perfil do docente: taxa de docentes com formação superior; Perfil do aluno: taxa de aprovação e taxa de adequação idade/série; Perfil da oferta: número médio de horas-aula diárias e número médio de alunos por turma. (FARENZENA, 2005, p. 15)

Nota-se que a pesquisa parte de determinada compreensão acerca do que seria um ensino de qualidade, compreensão esta que se reflete nos indicadores utilizados para a captação dos aspectos considerados pertinentes para a oferta de um ensino de qualidade. Ao que tudo indica, a concepção de qualidade percebida nos indicadores está em linha com aquela propugnada pela LDB, já que grande parte deles capta aspectos relativos aos recursos destinados às escolas. Tais aspectos, conforme mensurados, são úteis não só para a identificação da quantidade de recursos disponibilizada, mas também para a realização de análises acerca de como as escolas têm utilizado os recursos financeiros para a promoção do ensino. Por exemplo, escolas (ou redes de ensino) que apresentem um mesmo montante de despesas com salários de professores podem ter feito diferentes opções sobre a estratégia de uso de recursos: mais horas de aula com mais alunos por turma, turmas menores e menos horas de aula, salários mais altos e turmas grandes, etc.

\footnotetext{
${ }^{7}$ Além do IEE, cada grupo de pesquisadores pôde considerar a inclusão de escolas a partir de informações disponíveis em cada rede sobre a existência de escolas de qualidade que não foram selecionadas com base no índice desenvolvido pelo INEP (FARENZENA, 2005, p. 15). No Estado de Minas Gerais, por exemplo, um dos critérios considerados para a inclusão de escolas na amostra foi o resultado obtido no Sistema Mineiro de Avaliação Educacional - Simave (DUARTE e SANTOS, 2005, p. 76-77).
} 
Além das medidas relacionadas aos recursos presentes nas escolas, merece destaque a consideração da "taxa de aprovação dos alunos" como critério de seleção das escolas que oferecem condições para a oferta de um ensino de qualidade. Tendo em vista o significado de tal medida, aparentemente a pesquisa extrapolou a consideração de variáveis relacionadas às condições de oferta do ensino, selecionando as escolas de acordo com um possível resultado da oferta de um ensino de qualidade, que é a aprovação. Isto é, ao selecionar escolas a partir de critérios que envolvem a consideração não só de condições de oferta do ensino, mas também de medida de resultado, a pesquisa em questão inclui a dimensão dos resultados da educação escolar na representação de qualidade a que adere e, ao mesmo tempo, passa a explorar os custos de escolas que apresentam resultados desejáveis, considerando ser a aprovação dos alunos uma das consequências esperadas do ensino oferecido nas escolas. Diante disso, pode-se dizer que o trabalho em questão deu um passo importante no que diz respeito ao estudo das relações entre financiamento das escolas, uso dos recursos e resultados do ensino oferecido pelas escolas, já que explora estes três aspectos. De toda forma, é importante destacar que a pesquisa não explicitou a intenção de empreender este tipo de análise, mesmo porque, diante da não consideração do nível socioeconômico dos alunos, qualquer inferência acerca dos fatores associados aos resultados torna-se vaga, já que estes podem estar relacionados às características dos alunos e não a variáveis escolares.

Em relação aos custos das escolas, o estudo empreendeu o levantamento dos custos de funcionamento e de implantação destas, obtendo o custo por aluno a partir da divisão das despesas pelos alunos matriculados. As despesas, conforme mapeadas nas escolas, foram classificadas em: "instalações, pessoal, material de consumo, equipamento e material permanente e outros insumos", prevalecendo, portanto, o uso de categorias que apontam essencialmente para os insumos presentes em cada escola (FARENZENA, 2005, p. 19-21).

Conforme citado, a pesquisa em questão teve seus achados publicados em diversos trabalhos, tendo cada um destes um determinado foco. Assim, o trabalho de consolidação e análise da informação sobre o custo por aluno nas escolas que oferecem condições para a oferta de ensino de qualidade foi empreendido por Robert E. Verhine, que a partir da informação produzida nas unidades escolares dos oito estados envolvidos na pesquisa, explorou as principais tendências relativas aos custos das escolas, segundo as etapas e modalidades de 
ensino, assim como procurou mensurar os determinantes do custo por aluno nas escolas com condições para a oferta de ensino de qualidade (VERHINE, 2006, p. 13).

A publicação em questão traz uma série de indicadores que retratam o perfil das escolas da amostra. A consideração de aspectos para além do custo por aluno, que apontam para as condições de organização, funcionamento e gestão das escolas (p. 17), constitui um dos destaques da pesquisa, já que tal abordagem permite que se extrapole a análise centrada nos insumos presentes nas escolas, o que torna possível um tipo de investigação que busca entender em que se transformam, nas escolas, os recursos financeiros a elas destinados, assim como permite a análise dos diferentes usos dados a estes.

Dentre os indicadores que apontam para as condições de funcionamento e gestão, destacam-se os que exploram a existência e as condições de uso de dependências das escolas, a situação funcional, a experiência e a qualificação de docentes e diretores e o número de alunos por turma, dentre outros (p. 34-41). Em publicação baseada no mesmo conjunto de dados, destinada à análise de características relativas à qualidade do ensino oferecido pelas escolas da amostra, Camargo et al (2006) propõe que tais medidas sejam entendidas como categorias quantificáveis da qualidade das escolas, havendo ainda categorias que seriam mais subjetivas, mas também passíveis de serem captadas, sendo exemplos a motivação dos docentes para o trabalho e a gestão democrática das escolas (CAMARGO et al, 2006, p. 36).

Para a consolidação das informações sobre custos das escolas das diferentes regiões do país, Verhine (2006) propõe que sejam considerados o Custo-Aluno - Manutenção do Ensino (CAMAN) e o Custo-Aluno - Econômico (CA-ECO), sendo que o primeiro agrega as despesas com pessoal, material de consumo, material permanente e outros insumos, e o segundo considera, além destas, os custos associados às instalações (terreno e prédio) e à merenda escolar (p. 48).

Após a exclusão de duas escolas que apresentavam custos de terrenos muito elevados, distorcendo os resultados da amostra, são obtidos CA-MAN médio de R\$ 1.697,75 e CAECO de R\$2.020,69 para as 93 escolas consideradas, ficando registrada a grande variação 
nos valores do custo por aluno, que vão de $\mathrm{R} \$ 254,22$ a $\mathrm{R} \$ 7.879,11$ no caso do CA-MAN ${ }^{8}$. A análise dos dados permitiu constatar que as escolas com menores valores de custo por aluno situam-se nos estados que têm menores níveis de desenvolvimento econômico (p. 52).

Em relação à distribuição dos componentes do custo, segundo os diferentes tipos de despesa, nota-se novamente a concentração de gastos com o pagamento de salários de docentes e demais funcionários das escolas, cujo montante implica em $84 \%$ do CA-MAN ou $73 \%$ do CA-ECO das escolas da amostra (p. 53). A distribuição percentual do CA-ECO segundo as categorias de despesa, para as etapas e modalidade de ensino consideradas, indica a maior participação da despesa com docentes para os anos finais do ensino fundamental, em relação às demais etapas do ensino. Nota-se também a baixa participação da despesa com docentes na educação infantil, etapa que se destaca pela alta participação dos custos associados a prédios e terrenos e a materiais de consumo (p. 58).

Em relação ao nível do custo médio por aluno, destacam-se os maiores valores obtidos para creche e pré-escola, assim como para os cursos de formação profissional. Nota-se ainda o baixo valor obtido para o custo associado à oferta de educação especial. O autor aponta como possível explicação o fato do custo dessa modalidade de ensino ser, muitas vezes, embutido no custo da respectiva etapa da educação básica, sobretudo nos casos de educação especial inclusiva (p. 56). Assim, ao que tudo indica, seriam necessários estudos que mensurassem as despesas escolares em níveis menores de agregação, o que possibilitaria a identificação dos recursos associados aos alunos ou a grupos de alunos. Isto é, a mensuração dos gastos das escolas e sua divisão pelo total de alunos pode esconder nuances que implicam não só em subestimação ou superestimação das despesas segundo a etapa ou modalidade, mas também na dificuldade de estabelecimento da relação entre o financiamento das escolas e a alocação dos recursos recebidos, o que, por sua vez, pode comprometer análises que tenham como objetivo explorar relações entre recursos e resultados da educação escolar.

Na tentativa de delimitar os custos associados às melhores escolas da amostra - já constituída por escolas que oferecem condições para a oferta de ensino de qualidade -, o autor propõe a análise dos resultados por escolas de "qualidade especial". Tal qualidade é captada a partir de especificações exigentes quanto ao estado de conservação e uso do prédio e de suas

\footnotetext{
${ }^{8}$ Os valores estimados para o custo-aluno estão em reais correntes do ano em que foram obtidos os dados para a pesquisa, 2003.
} 
dependências, quanto ao percentual de professores pertencentes ao quadro permanente de docentes de cada escola, quanto à formação de docentes e diretores e quanto ao número de alunos por turma, que deveria ser no máximo 30 para educação infantil e ensino fundamental e 40 para o ensino médio, técnico e normal. A análise dos custos, por etapa e modalidade de ensino, das 33 escolas que se enquadraram nos critérios estabelecidos, indicou que o valor gasto por aluno destas escolas é bem mais alto que o das demais no caso do ensino fundamental, do ensino médio, do ensino técnico, da educação de jovens e adultos e da alfabetização, sendo menor no caso das creches (p. 61-62).

Em breve análise da relação entre o custo por aluno e indicadores que apontam para a qualidade na oferta do ensino, são apontadas relações positivas entre custo por aluno e condições satisfatórias de prédio e dependências, assim como forte relação entre custos e o número de alunos por turma. Os demais indicadores que apontavam para algum aspecto da qualidade do ensino oferecido, como os relativos à formação e experiência de docentes e diretores, não apresentaram relação significativa com o custo por aluno das escolas (p. 64-65).

Por fim, o autor se dedica à investigação dos principais determinantes do custo por aluno, tendo por base o CA-MAN. Considerando que os custos das escolas podem estar relacionados ao contexto das mesmas, às suas características e à qualidade escolar, foi empreendida análise quantitativa que procura dimensionar a relevância de variáveis associadas às dimensões citadas (contexto, características e qualidade), no que diz respeito à determinação do custo das escolas. As variáveis consideradas no modelo foram: localização rural ou urbana e nível de desenvolvimento econômico do Estado, relativas a contexto; número total de salas de aula, salário médio dos professores, relação matrícula/docente e dependência administrativa da escola, relativas a características das escolas; condições físicas e formação dos profissionais, relativas à qualidade escolar (p. 66).

Os resultados apontaram como de maior peso na determinação do custo por aluno as variáveis relativas às características das escolas, sendo as mais relevantes a relação matrícula/docente e a dependência administrativa. Merecem destaque também o nível de desenvolvimento econômico do Estado, o salário médio do professor e a formação dos profissionais (p. 67). Em relação à análise quantitativa empreendida, porém, resta a dúvida sobre serem as variáveis, conforme consideradas, determinantes do custo por aluno ou, ao menos em alguns casos, estas 
serem componentes do custo por aluno. Além disso, como o próprio autor observa, os resultados devem ser interpretados com cautela, já que as escolas selecionadas para a pesquisa não são fruto de uma amostra aleatória (p. 69).

Ao que tudo indica, a pesquisa que procurou conhecer o custo de escolas que oferecem condições para a oferta de um ensino de qualidade, coordenada pelo INEP e implementada por diversos grupos de pesquisadores e profissionais da educação de cada região do país, foi a que mais avançou, até o momento, na exploração de como os recursos presentes nas escolas são utilizados, pois não somente identificou a disponibilidade de recursos por aluno, em termos de custo, mas investigou as características de oferta do ensino, em cada escola, associadas a este custo. Nota-se, porém, que ainda que a taxa de aprovação dos alunos tenha sido considerada na seleção das escolas, não houve tentativa de associação entre o custo por aluno observado e tal resultado. De toda forma, este tipo de análise seria frágil sem a consideração do nível socioeconômico dos alunos.

Paralelamente aos esforços do INEP, cuja pesquisa, iniciada em 2003, tinha como um de seus propósitos a produção de informações que embasassem uma proposta de Custo AlunoQualidade (CARREIRA e PINTO, 2007, p. 39), diversos grupos e organizações da sociedade civil se dedicavam a discutir uma proposta de custo por aluno, segundo a etapa do ensino, que viabilizasse a oferta de um ensino de qualidade. Estas discussões, capitaneadas sobretudo pela Campanha Nacional pelo Direito à Educação, resultaram na proposta de um Custo AlunoQualidade Inicial (idem, 2007). Esta proposta, incorporada ao Plano Nacional de Educação 2014-2024, mostra-se essencial para que se rompa com a tradicional prática de viabilizar a qualidade possível e não a desejada, em termos de ensino, a partir do escasso recurso colocado à disposição da educação pública (OLIVEIRA e ARAUJO, 2005, p. 18).

A pesquisa empreendida pelo INEP, assim como a proposta de CAQi de Carreira e Pinto (2007), rompem com o foco predominante, até então, dos estudos dedicados ao exame dos gastos escolares, buscando menos a identificação de custos e a produção de informações que contribuam para uma alocação "ótima" dos recursos disponíveis e mais a definição do gasto necessário para que se viabilize o ensino que deve ser garantido. De toda forma, os estudos sobre gastos escolares, até o momento, tendem a não dar grande destaque às possibilidades de relação entre gastos por aluno e aspectos relativos aos resultados do ensino. Ou seja, são 
estimados os gastos associados à oferta do ensino, mas não os associados à aprendizagem dos alunos ou a outro resultado que seja entendido como relevante.

Neste trabalho, parte-se do entendimento de que a consideração da aprendizagem dos alunos como referência para a análise dos gastos das escolas é pertinente, já que uma das finalidades do ensino de qualidade a ser viabilizado pela adequada disponibilização de recursos é a aprendizagem. Isto é, sendo um dos propósitos dos recursos disponibilizados a garantia do aprendizado, torna-se relevante o estudo de contextos escolares em que este propósito se realiza e de aspectos acerca de como se dá tal realização, assim como de situações em que os recursos disponibilizados às escolas não cumprem o papel a eles atribuído, seja devido à insuficiência, seja por causa das opções feitas acerca da alocação ou do uso dos recursos disponíveis.

Ainda que a disponibilidade e consolidação do uso de resultados de testes padronizados, no Brasil, contribua para a viabilização de estudos que explorem a relação entre os gastos por aluno e o desempenho, a realização deste tipo de pesquisa é dificultada pela indisponibilidade de informações sobre gastos no nível das unidades escolares. A execução da despesa pública no âmbito educacional ocorre, em geral, nas secretarias de educação ou nas diretorias de ensino, não sendo atribuído às escolas o status de unidade de despesa ${ }^{9}$. Desta forma, não são facilmente delimitadas as despesas em que incorrem as escolas para a manutenção de suas atividades, pois a maior parte delas é realizada, do ponto de vista da execução do orçamento público, em instâncias externas às escolas. Além disso, tal realização da despesa pública se dá de forma agregada, correspondendo a gastos que vão propiciar o atendimento a mais de uma escola e a mais de uma etapa ou modalidade de ensino. Soma-se a isto o fato de que as despesas com bens duráveis, no orçamento público, são atribuídas integralmente ao ano em que foram realizadas, não havendo, em geral, a distribuição de tal despesa no tempo, conforme a vida útil de cada bem, tendo em vista a depreciação destes. Assim, mesmo que, em alguns casos, parte da informação sobre as despesas escolares possa ser obtida em instâncias externas às escolas (como ocorre com os salários, por exemplo, que poderiam ser obtidos diretamente nas secretarias de educação), em geral, faz-se necessário o levantamento de informações in loco, sobretudo no que diz respeito aos materiais consumidos no dia-a-dia,

\footnotetext{
${ }^{9}$ Unidade de despesa é a denominação atribuída à Unidade Gestora Executora, sendo esta uma "unidade codificada no sistema componente da estrutura dos órgãos da Administração Direta, autarquias e fundações incumbidas das execuções orçamentária e financeira da despesa propriamente dita" (MACHADO, 2002, p. 165)
} 
à disponibilidade e valoração de bens duráveis (como, por exemplo, computadores, mesas, equipamentos de cozinha etc.) e aos serviços ou materiais adquiridos com recursos financeiros obtidos diretamente pelas escolas (sobre este último tema, ver SOUZA, 2006, p. 256). Diante do exposto, pode-se dizer que a dificuldade em torno da produção deste tipo de informação torna trabalhosa a análise de relações entre desempenho e custos ou gastos por aluno, no nível da escola, a partir de grandes amostras.

Além da consideração dos gastos escolares, o tipo de análise em questão deve levar em conta o nível socioeconômico dos alunos das escolas, já que a maior parte da variação do desempenho em testes padronizados é explicada não pelas características das escolas, mas pelo background familiar dos alunos. A construção de indicadores que expressem o nível socioeconômico de alunos, contudo, ainda que possível, não é de fácil viabilização e, quando implementadas, as opções metodológicas feitas não são imunes a críticas ou ressalvas (ver ALVES e SOARES, 2009).

Outro ponto sensível no que diz respeito ao estudo de relações entre os gastos efetuados pelas escolas e o desempenho dos alunos é a própria fragilidade desta última medida, que seria uma espécie de proxy para a aprendizagem, sendo a aprendizagem um dos resultados possíveis e desejáveis da educação escolar. Alves e Soares (2008, p. 530) diferenciam o desempenho em testes padronizados da aprendizagem, indicando que o primeiro é o registro de um conjunto de habilidades e competências em um momento do tempo, sendo a aprendizagem algo que se dá em um intervalo de tempo. Assim, só seria possível a captação da aprendizagem por meio do acompanhamento, durante determinado período, da evolução do desempenho dos alunos. A discussão, contudo, do período de tempo necessário para que se possa captar a aprendizagem que supostamente deveria ter ocorrido, através de avaliações, não parece ser trivial, considerando a complexidade do processo de ensino-aprendizagem. De toda forma, partindo do entendimento de que o desempenho em testes padronizados possa representar, em alguma medida, as habilidades e competências desenvolvidas pelos alunos durante o processo de aprendizagem, parece possível que tal desempenho seja utilizado para fins de representação da aprendizagem, em determinado momento (OLIVEIRA et al, 2013, p. 21).

Ainda em relação às dificuldades a serem enfrentadas em estudos que procuram explorar as relações entre recursos e resultados da educação escolar, pode-se dizer que estes 
frequentemente correm o risco de 1) tomar como de pouca relevância aspectos que não são passíveis de mensuração; e 2) desconsiderar características não cognitivas do desenvolvimento dos alunos. Assim, ainda que esta pesquisa se proponha a analisar os gastos de escolas tendo como referência o desempenho médio de seus alunos, ambas categorias passíveis de mensuração, vale destacar que as condições para um ensino de qualidade extrapolam em muito a esfera dos recursos (CAMARGO et al, 2006), assim como os resultados da educação escolar não se limitam nem ao que é possível de se medir, nem aos aspectos do desenvolvimento cognitivo de crianças e adolescentes.

Há um modo de se entender as questões de educação e de ensino que, ao privilegiar a formação como lento processo de incorporar e reconfigurar as relações com o conhecimento e com a realidade, dá pouco espaço à ideia de que se possa saber, prontamente, e sempre, os resultados daquilo que se ensina. Os efeitos mais significativos dos processos educacionais seriam, assim, aqueles que não se prestam a serem exaustivamente avaliados durante ou ao final dos períodos formais de ensino. Sem dúvida, a ideia que alicerça as esperanças mais fortes numa educação capaz de cumprir um papel estruturante das melhores possibilidades das pessoas, ao utilizar das experiências de formação para permitir uma real aproximação dos sujeitos com a realidade, a vida social, a solidariedade e a busca de formas mais dignas para a existência humana, nem sempre fica clara e presente no dia a dia da vida escolar onde, de todos os modos, é preciso assegurar a aquisição de habilidades básicas como ler, escrever, contar, compreender as linguagens das variadas disciplinas científicas e outras tantas tarefas, sem dúvida, vitais. (CATANI e GALLEGO, 2009, p. 13)

A despeito das dificuldades e ressalvas expostas, pode-se entender que a análise da alocação e do uso dos recursos educacionais, considerada a condição social dos alunos, pode ser útil para a compreensão e disseminação de práticas que contribuam para que os recursos disponibilizados às escolas cumpram seu papel na promoção de um ensino de qualidade.

\subsection{Custo, gasto e despesa}

A revisão da literatura que trata do que tem sido chamado de "custo-aluno", no Brasil, apresenta uma profusão de termos similares que são utilizados de diferentes maneiras, tanto entre diferentes autores quanto no contexto de uma mesma pesquisa. Custo, gasto e despesa são tratados como sinônimos, em alguns casos. Custo direto e indireto nem sempre significam a mesma coisa, a depender do referencial teórico e metodológico de cada pesquisa. 
O que é comum entre os trabalhos que tratam do tema é a apropriação de um referencial relacionado a ambientes produtivos. Em linhas gerais, os estudos de viés econômico, entendendo a escola como uma unidade produtiva, procuram identificar os insumos que entram nas escolas e estabelecem algum tipo de relação entre esses insumos e determinado resultado ou retorno econômico. A ausência de relação entre insumos e produtos indicaria algum tipo de problema no processamento dos insumos ou na pouca relevância dos insumos para o resultado considerado. Nestes estudos, geralmente importa o montante total de recursos dispendidos para a manutenção das escolas e sistemas de ensino e o custo de oportunidade destes recursos, já que as escolas, como qualquer unidade de produção, estão imobilizando um conjunto de recursos que poderia ter uma aplicação alternativa. Além disso, estas pesquisas consideram o custo de oportunidade referente aos salários não recebidos pelos alunos enquanto se dedicam aos estudos, sendo este classificado como custo indireto.

Outra abordagem de pesquisa, geralmente menos focada no resultado ou no retorno dos gastos destinados à educação e mais preocupada em identificar os recursos necessários para o funcionamento das escolas, tende a calcular o custo-aluno com base em critérios mais próximos à contabilidade de custos. Neste caso, é comum a divisão dos custos em diretos e indiretos e a aplicação de rateios para o direcionamento do custo indireto, prática geralmente associada ao método de Custeio por Absorção ${ }^{10}$. Neste caso, geralmente os custos indiretos são aqueles externos à escola, efetuados pelo sistema de ensino (secretarias de educação, diretorias de ensino etc.) para suporte às atividades desenvolvidas pelas escolas. Os custos diretos são tratados como aqueles restritos às unidades de ensino.

A Tabela 3 indica as diferentes abordagens utilizadas, para o tratamento do custo por aluno, pelos estudos indicados na seção anterior. Nota-se que o que é considerado custo total, custo direto e custo indireto varia, ainda que todos os autores tenham se dedicado a delimitar um conjunto de despesas que possa ser atribuído a um determinado grupo de escolas em um certo período de tempo. Em especial, o esforço para a obtenção dos valores relativos à depreciação de recursos escolares que são utilizados por diversos anos (prédios, equipamentos etc.) torna a informação produzida coerente, em maior ou menor grau a depender da pesquisa, com a informação de custo. A análise da tabela não permite inferir que a abordagem de algum autor

\footnotetext{
${ }^{10}$ Custeio por absorção "consiste na apropriação de todos os custos de produção aos bens elaborados, e só os de produção; todos os gastos relativos ao esforço de produção são distribuídos para todos os produtos ou serviços feitos" (MARTINS, 2003, p. 24).
} 
é preferível às outras. Todas podem se mostrar úteis a depender dos objetivos de cada pesquisa.

TABELA 3 - CUSTO TOTAL, DIRETO E INDIRETO NOS LEVANTAMENTOS DE CUSTOALUNO

\begin{tabular}{|c|c|c|c|}
\hline Autores & Custo total & Custo direto & Custo indireto \\
\hline $\begin{array}{l}\text { CAMPINO E } \\
\text { NUNES } \\
\text { (1970) }\end{array}$ & $\begin{array}{l}\text { Custos sociais: } \\
\text { incorridos pela } \\
\text { sociedade para a } \\
\text { manutenção do ensino; } \\
\text { excluem gastos privados } \\
\text { dos estudantes e famílias }\end{array}$ & $\begin{array}{l}\text { Despesas correntes e de } \\
\text { capital (custo de } \\
\text { oportunidade e } \\
\text { depreciação) das escolas } \\
\text { e do sistema de ensino }\end{array}$ & $\begin{array}{l}\text { Salários não-recebidos } \\
\text { pelos estudantes } \\
\text { enquanto se dedicam } \\
\text { aos estudos }\end{array}$ \\
\hline $\begin{array}{l}\text { CASTRO, } \\
\text { ASSIS E } \\
\text { OLIVEIRA } \\
(1972)\end{array}$ & $\begin{array}{l}\text { Custos sociais: } \\
\text { incorridos pela } \\
\text { sociedade para a } \\
\text { manutenção do ensino; } \\
\text { excluem gastos privados } \\
\text { dos estudantes e famílias }\end{array}$ & $\begin{array}{l}\text { Despesas correntes e de } \\
\text { capital (custo de } \\
\text { oportunidade, } \\
\text { depreciação e gastos } \\
\text { com manutenção) das } \\
\text { escolas e do sistema de } \\
\text { ensino }\end{array}$ & $\begin{array}{l}\text { Salários não-recebidos } \\
\text { pelos estudantes } \\
\text { enquanto se dedicam } \\
\text { aos estudos }\end{array}$ \\
\hline PARO (1981) & $\begin{array}{l}\text { Custo de instalação e de } \\
\text { funcionamento das } \\
\text { unidades de ensino. Não } \\
\text { considera custos da rede } \\
\text { e de oportunidade }\end{array}$ & \multicolumn{2}{|c|}{$\begin{array}{l}\text { O autor diferencia as despesas das escolas das de } \\
\text { administração do sistema de ensino, mas não } \\
\text { utiliza a classificação de custos diretos e indiretos. } \\
\text { As despesas são divididas em correntes, sociais e } \\
\text { de capital (depreciação e gastos com manutenção), } \\
\text { sendo consideradas somente as relativas às } \\
\text { unidades de ensino }\end{array}$} \\
\hline $\begin{array}{l}\text { XAVIER E } \\
\text { MARQUES } \\
(1988)\end{array}$ & $\begin{array}{l}\text { Custo de funcionamento } \\
\text { das unidades de ensino. } \\
\text { Não considera custos da } \\
\text { rede, de instalação e de } \\
\text { oportunidade }\end{array}$ & $\begin{array}{l}\text { Despesas correntes e de } \\
\text { capital (depreciação e } \\
\text { gastos com manutenção) } \\
\text { das unidades de ensino }\end{array}$ & $\begin{array}{l}\text { Custos relativos à } \\
\text { administração central } \\
\text { do sistema educacional } \\
\text { (Secretaria de } \\
\text { educação, diretoria de } \\
\text { ensino etc.) }\end{array}$ \\
\hline $\begin{array}{l}\text { FARENZEN } \\
\text { A (2005) / } \\
\text { VERHINE } \\
(2006)\end{array}$ & $\begin{array}{l}\text { Custo de instalação e de } \\
\text { funcionamento das } \\
\text { unidades de ensino. Não } \\
\text { considera custos da rede }\end{array}$ & $\begin{array}{l}\text { Despesas correntes e de } \\
\text { capital (depreciação, } \\
\text { gastos com manutenção } \\
\text { e custo de oportunidade } \\
\text { do terreno da escola) }\end{array}$ & $\begin{array}{l}\text { Custos relativos à } \\
\text { administração central } \\
\text { do sistema educacional } \\
\text { (Secretaria de } \\
\text { educação, diretoria de } \\
\text { ensino etc.) e aos } \\
\text { salários não-recebidos } \\
\text { pelos estudantes } \\
\text { enquanto se dedicam } \\
\text { aos estudos }\end{array}$ \\
\hline
\end{tabular}

Fonte: Elaborado a partir dos trabalhos indicados na tabela.

Para os propósitos desta pesquisa, interessa conhecer as despesas que podem ser atribuídas a um conjunto de atividades desempenhadas pelas escolas em um período de tempo e que 
relações os recursos que viabilizaram estas atividades têm com os resultados dos alunos neste mesmo momento do tempo. Sendo assim, pode-se dizer que a informação que mais se aproxima do que proponho que seja utilizado para a exploração da relação entre gastos e desempenho é a informação de custo conforme utilizada pela contabilidade de custos.

Talvez mais importante do que a definição de custo a ser seguida, seja a distinção entre gastos, despesas e custos. Martins (2003) indica que gasto está relacionado com o sacrifício financeiro relativo à "compra de um produto ou serviço qualquer" (p. 17). Como indica Alves (2009), no orçamento público, que constitui o foco dessa pesquisa, gastos e despesas seriam termos que representam uma mesma ideia, já que a despesa pública pode ser definida como "o conjunto de dispêndios do Estado no atendimento dos serviços e encargos assumidos no interesse da população" (SILVA, 2009, p. 240).

Diante do exposto, pode-se dizer que a despesa ou o gasto público com educação pública trata de todo o recurso financeiro utilizado para implantação e manutenção de escolas e redes de ensino, mas só seria considerado custo o gasto público que pode ser atribuído a um conjunto determinado de escolas em determinado período. Esta diferenciação é relevante porque os trabalhos que procuram mensurar a relação entre gastos com educação e desempenho utilizam, como será visto adiante, dados de gastos e não de custo. Isto é, são tomadas, por exemplo, as despesas executadas com o ensino fundamental em um ano, de forma agregada por município ou estado, e mensurada a relação entre estas despesas e o desempenho médio dos alunos do ensino fundamental. Exemplifico o potencial problema: é possível que a despesa liquidada por aluno em determinado ano seja reflexo de uma grande compra de materiais e equipamentos, ou da execução de qualquer outro tipo de despesa (execução de obras para acessibilidade, por exemplo) que, apesar de ter implicado em grande gasto neste ano, não deve, necessariamente, implicar em resultados de qualquer espécie, proporcionalmente ao gasto, neste mesmo ano. Isto é, não é porque houve uma grande variação na despesa do município, em determinada etapa ou modalidade da despesa com educação, que deve ser esperada uma variação correspondente no resultado, já que esta despesa pode estar relacionada com a formação de um estoque de capital, que terá seus efeitos sobre determinados resultados no decorrer do tempo (esta possível distorção é minimizada quando levada em conta a depreciação de materiais e equipamentos que as escolas utilizam para o ensino). Desta forma, considero que a melhor informação para o estabelecimento da 
relação entre recursos e desempenho guarda relação com a informação de custo por aluno e não com a informação de gastos ou despesas por aluno. Por outro lado, tendo em vista que a principal despesa com educação se refere a pagamento de salários e que estes valores serão os mesmos tanto na despesa por aluno quanto no custo por aluno, é possível que a informação de custo por aluno e de despesa por aluno sejam próximas em boa parte dos casos.

Foram exploradas, até aqui, possibilidades de construção da informação sobre recursos escolares no nível das escolas, considerando que este tipo de dado é relevante para a compreensão da relação entre gastos e desempenho. Os estudos que produziram este tipo de informação, contudo, não tiveram a intenção de estabelecer uma relação entre gastos e desempenho. Por outro lado, as pesquisas dedicadas ao estudo desta relação tomam como base dados agregados da despesa pública com educação, geralmente no nível municipal, já que essa é a informação de gasto produzida sistematicamente no Brasil. A seção seguinte trata brevemente dessa literatura. Como será possível perceber, as restrições já indicadas acerca do uso de dados de despesas públicas agregadas no nível dos municípios para o fim em questão se confirmam e se somam a outras.

\subsection{Gastos educacionais e desempenho escolar no Brasil}

Poucos são os trabalhos que, no Brasil, se dedicam a explorar a relação entre gastos e desempenho dos alunos. As pesquisas existentes, em geral, utilizando dados da despesa pública no nível do município, relativos à determinada etapa da educação básica, estimam a relação entre gastos e o desempenho dos alunos em língua portuguesa e/ou matemática. Tendo em vista o escopo desta pesquisa, consideramos os trabalhos que tratam especificamente da relação entre gasto ou despesa pública e desempenho. Desta forma, não tratamos das pesquisas que exploram a relação entre recursos - materializados na forma de equipamentos, tamanho de turmas, infraestrutura etc. - disponibilizados às escolas e o desempenho dos alunos.

Menezes-Filho e Pazello (2007), utilizando dados do SAEB de 1997 e 1999, exploram os efeitos da variação de recursos no ensino fundamental, propiciada pela criação do Fundo de Manutenção e Desenvolvimento do Ensino Fundamental e de Valorização do Magistério Fundef, sobre o salário dos professores e sobre a proficiência dos alunos da rede pública. Os 
autores indicam que o Fundef implicou em aumento dos salários dos professores da rede pública, e que esta variação positiva dos salários teve impacto positivo sobre o desempenho dos estudantes no período.

Amaral e Menezes-Filho (2008) utilizam dados de despesas com ensino fundamental dos municípios para verificar se os gastos por aluno estão associados ao desempenho em português e matemática dos alunos da quarta e oitava séries na Prova Brasil de 2005. Considerando como controles as variáveis anos de estudo de maiores de 25 anos, percentual médio de docentes com curso superior, número de horas de aula por dia e os estados a que cada município pertence, os autores encontram associação positiva e significante entre gastos e o desempenho médio das escolas dos municípios em matemática, para os alunos da quarta série. Não foi obtida relação significante entre gastos e o desempenho dos alunos da quarta série em língua portuguesa e entre gastos e proficiência dos alunos da oitava série. Os autores indicam que, apesar da associação positiva obtida, o coeficiente estimado é muito baixo, de forma que um aumento de $1 \%$ no gasto por aluno estaria relacionado a uma variação positiva de $0,8 \%$ na nota em matemática dos alunos da quarta série. Assim, apontam que "o impacto dos gastos em educação sobre o desempenho escolar não tem relevância prática significativa" (p. 12).

Amaral (2011) utiliza a transição do Fundo de Manutenção e Desenvolvimento do Ensino Fundamental e de Valorização do Magistério - FUNDEF para o Fundo de Manutenção e Desenvolvimento da Educação Básica e de Valorização dos Profissionais da Educação FUNDEB, em 2006, para verificar se o aumento do gasto por aluno matriculado no ensino fundamental associado a esta transição impactou positivamente o desempenho dos alunos do ensino fundamental dos municípios. Com base em um painel de dados de desempenho e gastos municipais para os anos de 2005 e 2007, o autor identifica o impacto positivo dos gastos sobre as notas médias dos municípios na Prova Brasil em português e matemática, para a oitava série, e em matemática, no caso dos alunos da quarta série. $\mathrm{O}$ efeito observado dos gastos sobre o desempenho, contudo, não é grande. Para o maior coeficiente estimado (que associa o gasto por aluno ao desempenho em matemática dos alunos da quarta série), seria necessário um aumento de mil reais ao ano no gasto por aluno para que houvesse um aumento de $10 \%$ no desempenho. 
Diaz (2012) explora a relação entre gastos e o Índice de Desenvolvimento da Educação Básica - IDEB dos municípios brasileiros para ano de 2005, sendo este índice calculado com base no desempenho médio dos alunos na Prova Brasil e na taxa de aprovação escolar. A autora faz uso de modelos multinível com dois níveis (escolas e municípios) para estimar a relação entre gastos e o IDEB, o que permite a consideração de variáveis relativas ao perfil socioeconômico médio dos alunos, às condições de infraestrutura das escolas e às características do corpo docente, no nível das escolas, além do controle de características dos municípios. Em relação aos gastos, a pesquisa testa os efeitos do percentual de gastos com educação em relação à despesa pública total de cada município, do percentual de gastos com ensino fundamental em relação ao gasto total com educação e do gasto com ensino fundamental por aluno, sobre o IDEB dos municípios. As estimativas levaram em consideração os resultados do IDEB para os anos iniciais do ensino fundamental. Sobre os resultados obtidos, a autora indica que:

[...] relativamente às medidas de gastos verificam-se dois resultados distintos: sinal positivo para a variável gasto municipal por aluno, apesar de dimensão muito pequena, indicando que quanto maior o gasto municipal por aluno maior é o valor do IDEB esperado e sinais negativos tanto para o percentual das despesas com educação em relação às despesas municipais totais como para o percentual das despesas com ensino fundamental em relação às despesas com educação.

Estes resultados parecem indicar a existência de um pequeno impacto positivo do gasto municipal por aluno. Porém, quando se avaliam os gastos gerais, refletidos nas variáveis percentuais analisadas, verifica-se que estas variáveis refletem opções políticas que não necessariamente são acompanhadas por mudanças em aspectos que diretamente afetariam as condições ou os fatores que efetivamente são responsáveis pela melhoria da qualidade do ensino municipal. Assim, os resultados parecem indicar que simples aumentos de gastos com educação não necessariamente causam melhoria da qualidade do ensino, conforme mensurada pelo IDEB. (DIAZ, 2012, p. 138)

Em relação aos resultados indicados, pode-se sugerir que as medidas de percentuais de gastos com educação ou com ensino fundamental são úteis para a identificação de prioridades ou de necessidades de financiamento dos municípios, mas não parecem ser bons indicadores da disponibilidade de recursos escolares. Municípios com baixa receita per capita podem destinar proporcionalmente muitos recursos à educação e simultaneamente ter baixos valores de gastos por aluno, ou o contrário. Como indicado pela autora, quando considerado o gasto por aluno, que parece ser a medida mais adequada para a análise da relação entre gastos e o 
resultado em questão, a relação positiva entre gastos e o IDEB é observada, ainda que o valor do coeficiente estimado seja baixo.

Menezes-Filho e Oliveira (2014) utilizam dados em painel para avaliar a relação entre gastos por aluno no ensino fundamental e o desempenho dos alunos de quarta e oitava séries na Prova Brasil. Com base em informações de gastos e desempenho no nível municipal para os anos de 2005, 2007, 2009 e 2011, os autores identificam que, após o controle de características dos municípios que não variam no tempo e que podem estar associadas tanto ao gasto por aluno quanto ao desempenho, a relação entre gastos e desempenho é insignificante ou negativa, sendo o resultado válido também para as especificações que testam variáveis de gastos com dois anos de defasagem em relação ao desempenho. Os autores apontam como possibilidades de explicação para os resultados observados a inadequada utilização dos recursos, erros de medida dos dados de gasto, conforme reportados pelos municípios e a existência de endogeneidade ${ }^{11}$, caso o gasto por aluno esteja relacionado a fatores não observados.

Monteiro (2015) utiliza a variação de gastos com educação proporcionada pelo recebimento de royalties do petróleo para avaliar o impacto do aumento dos gastos sobre o desempenho dos alunos na Prova Brasil. Em uma primeira abordagem, são realizadas estimativas para identificar se a receita adicional gerada pelos royalties do petróleo implica em aumento dos gastos com educação nos municípios que recebem estes recursos adicionais, relativamente aos municípios vizinhos que não receberam. Verificado o impacto do aumento de receitas, propiciado pelos royalties, sobre a despesa pública com educação dos municípios considerados, a autora passa a avaliar se o aumento da despesa municipal per capita com educação implicou em melhoria do desempenho dos alunos de quarta e oitava séries na Prova Brasil, no período 2005-2011. Os resultados apontaram que a despesa adicional com educação

\footnotetext{
11 "Basicamente, o problema de endogeneidade ao qual tais estimativas estão sujeitas pode ser descrito como um problema de variável omitida. Inferências simples deixam de incorporar a qualidade inerente dos alunos. Como tal variável provavelmente é correlacionada com gastos em educação, as estimativas de impacto destes sobre a qualidade do ensino é viesada e inconsistente. Mais precisamente, há vários motivos para acreditar que gastos em educação tenham alguma correlação com a qualidade inerente dos alunos (habilidade). É possível que gestores de escolas, ou secretários de educação, tentem, por exemplo, contornar as dificuldades de turmas de habilidade menor aumentando os recursos empregados no ensino. Outra possibilidade é que municípios com menor habilidade média e, portanto, mais pobres, tenham menos recursos para investir em educação. Infelizmente, pelos dois exemplos, fica impossível definir a priori qual será o sinal do viés de estimativa por mínimos quadrados ordinários" (AMARAL, p. 19, 2011).
} 
dos municípios que contaram com receitas provenientes de royalties não implicou em melhoria relativa do desempenho na Prova Brasil em língua portuguesa e matemática.

Os resultados indicam que os gastos extras em educação gerados pelos recursos de royalties dos municípios produtores da costa não causaram nenhuma melhora nas notas gerais e de matemática da Prova Brasil, em comparação com os municípios da costa que não receberam esses recursos. Nota-se ainda que o recebimento de royalties está associado a uma queda da nota média de português. $\mathrm{O}$ aumento adicional de despesa em educação em municípios produtores de petróleo ( $\mathrm{R} \$ 84$ per capita ano) está associado a uma taxa de crescimento da nota média municipal de português, em média, 2 pp menor do que a apresentada pelos municípios não produtores de petróleo para a quarta série. Para a oitava série esse número é de 1 pp. (MONTEIRO, 2015, p. 480)

$\mathrm{Na}$ tentativa de verificar o canal por meio do qual o aumento de gastos se materializou nas escolas, o trabalho identifica que não houve efeito dos gastos no número de escolas ou de matrículas per capita, assim como não foram observadas alterações em variáveis indicativas da disponibilidade de professores por aluno. O salário dos professores foi o único fator relativo a recursos, dentre os testados, que foi impactado pelo aumento dos gastos, apresentando variação positiva de $9 \%$ em relação à média amostral. A conclusão, portanto, é a de que o aumento dos salários não se refletiu em melhoria do desempenho dos alunos.

Em relação às medidas utilizadas no estudo, além da consideração de dados das despesas municipais com educação como um todo como referência para a relação entre gasto e desempenho dos alunos do ensino fundamental, foi levado em conta o gasto com educação per capita, indicador que pode ter comportamento diferente do gasto por aluno, a depender da dinâmica de expansão de matrículas dos municípios.

Ainda em relação às medidas de gasto com educação da referida pesquisa, parece positiva a opção de considerar a variação entre a média da despesa de três anos (média de 2009-2011 em relação à média de 2003-2005). A abordagem seguida tende a considerar os efeitos que gastos passados possam ter sobre o desempenho dos alunos e suaviza variações da despesa pública que possam ter ocorrido por conta de grandes compras de materiais ou equipamentos, realização de obras ou outros tipos de despesa que impliquem em acumulação de recursos que serão utilizados por diversos anos. Como indicado anteriormente, a informação de despesa ou gasto público com educação pode não ser a melhor para a mensuração da relação entre gastos e desempenho, sendo preferível a consideração do custo. $\mathrm{O}$ tratamento dado à informação de 
gasto neste caso, contudo, tende a minimizar os problemas associados ao uso de dados de despesa pública para o estabelecimento de relações entre gastos e desempenho.

A despeito das conclusões de cada pesquisa, vale notar que os dados de proficiência utilizados dizem respeito ao desempenho médio dos alunos de quarta e oitava séries para cada município, enquanto os dados de gastos geralmente se referem ao gasto por aluno do ensino fundamental como um todo. Desta forma, não é possível estimar a relação entre gastos por aluno e desempenho separadamente, para os anos iniciais e finais do ensino fundamental, o que torna as estimativas da relação entre gastos e desempenho sujeitas a ressalvas, já que não é possível identificar como as redes de ensino alocaram os recursos entre os anos iniciais e finais do ensino fundamental. A inexistência de informações desagregadas para os anos iniciais e finais da despesa pública com ensino fundamental no Brasil inviabiliza, contudo, outras possibilidades de abordagem. Assim, para estimar a relação entre as variáveis em questão em agregação diferente da usual, é necessário que a pesquisa que pretende fazê-lo construa a informação de gasto a ser utilizada.

Além do exposto, é possível identificar certa restrição nas variáveis de controle utilizadas, que em geral são consideradas no nível do município e não no nível da escola. Tal restrição se reflete na adoção de medidas que podem não indicar adequadamente o nível socioeconômico médio dos alunos das escolas, já que, ao menos em alguns casos, as variáveis consideradas para tal fim refletem a média populacional dos municípios e não a média da situação socioeconômica dos alunos atendidos pelas escolas públicas consideradas.

Outra questão recorrente nos trabalhos que procuram estabelecer uma relação entre gastos e desempenho diz respeito à endogeneidade dos gastos. Esse problema ocorre em análises em que não é possível determinar se o montante de recursos destinado às redes de ensino ou escolas independe de fatores que não podem ser observados. Na prática, a ocorrência de endogeneidade implica na impossibilidade de sabermos, por exemplo, se o gasto está influenciando o desempenho ou se o desempenho está influenciando o gasto, o que inviabiliza a identificação de uma relação de causalidade. Por exemplo, um conjunto de escolas com grande proporção de alunos com baixo desempenho pode estar recebendo recursos adicionais justamente por causa do baixo desempenho dos alunos, o que poderia se traduzir em professores mais experientes (possivelmente com maiores salários), mais professores para o 
atendimento dos alunos em aulas de reforço etc. É possível que, para esse conjunto hipotético de escolas, seja observada uma relação negativa entre gastos e desempenho, o que não permite a conclusão de que um gasto maior implica em piora do desempenho. Para contornar esse tipo de problema, parte dos trabalhos citados fez uso de alguma situação ou fator que, como consequência de uma decisão de política pública, implicou em uma variação do gasto que não foi influenciada pelo desempenho dos alunos. Este foi o caso da implantação do FUNDEF, da transição do FUNDEF para o FUNDEB e dos royalties do petróleo. Ainda que o uso de instrumentos que permitam o estabelecimento de uma relação de causalidade seja o ideal, análises de regressão com dados relativos a um só período, sem a consideração de fatores que permitam a identificação de causalidade, podem ser úteis em uma primeira abordagem, dando indícios de questões a serem exploradas outros tipos de análise. Além disso, caso seja possível identificar parcelas do gasto que são influenciadas pelo desempenho dos alunos (gastos adicionais com aulas de reforço ou recuperação, por exemplo), o problema da endogeneidade pode ser minimizado, já que uma parcela do gasto que é influenciada pelo desempenho dos alunos poderia ser considerada. Para isso, contudo, é necessária certa desagregação dos dados relativos a gastos, assim como a associação entre os gastos e as atividades escolares correspondentes a eles.

Como é possível notar até aqui, a análise da relação ente gastos e desempenho é limitada pela inexistência de produção sistemática de dados desagregados de gastos com educação. Diante disso, parece haver necessidade da exploração de possibilidades de construção de informações sobre gastos com educação que estejam mais relacionadas ao que se passa nas escolas e que possam ser úteis não só para a verificação da relevância ou não do gasto, mas para a análise de como diferentes formas de alocação dos recursos podem estar associadas ao desempenho dos alunos. No próximo capítulo procuramos avançar nesse sentido. Nele será explorada parte da literatura norte-americana dedicada ao exame da alocação e do uso dos recursos no nível das escolas, tendo em vista a promoção da melhoria da aprendizagem dos alunos. Partindo das diferenças de necessidades de financiamento das escolas, são indicadas possibilidades de tratamento e análise dos dados de gastos escolares que sejam úteis para o entendimento de como gastos e desempenho dos alunos se relacionam. 


\section{Gasto no nível da escola e desempenho: abordagens e considerações baseadas no contexto norte-americano}

A literatura norte-americana apresenta certa profusão de estudos sobre recursos e gastos escolares. Berne e Stiefel (1997) classificam tais estudos em três tipos: 1) aqueles baseados em análise de funções de produção, que procuram estabelecer relações entre recursos e resultados, sendo frequente a utilização do desempenho dos alunos em testes padronizados como resultado; 2) estudos que exploram aspectos relativos à equidade na distribuição dos recursos disponíveis para o financiamento das escolas, sendo a análise quase sempre focada na distribuição de recursos entre distritos e 3) pesquisas interessadas em compreender como os recursos, viabilizados via financiamento, são alocados e utilizados nas escolas.

O segundo tipo de estudos ocupou grande parte do debate sobre a alocação dos recursos educacionais nos Estados Unidos durante as últimas décadas. Paralelamente à produção baseada em funções de produção, que se estendia em torno do debate sobre a relevância ou não da alocação de recursos adicionais às escolas para a melhoria do desempenho dos alunos, a discussão em torno da equidade na alocação dos recursos existentes tornou-se central nos Estados Unidos, dando origem inclusive a determinações de mudança da forma de financiamento, por parte das cortes do país (KIMBALL, 2009, p. 15-17). Ainda que melhorias na distribuição dos recursos educacionais entre distritos tenha ocorrido nos últimos anos, a forma de financiamento, baseada principalmente em impostos locais sobre a propriedade, continua sendo fonte de iniquidade na alocação dos recursos escolares. Assim, persiste, em alguma medida, situações em que escolas que atendem alunos provenientes de famílias de baixa renda contam com poucos recursos para o desenvolvimento de suas atividades, enquanto escolas que atendem alunos de elevado nível socioeconômico têm à sua disposição grande quantidade de recursos, o que costuma se traduzir em turmas menores, professores melhor remunerados e infraestrutura escolar adequada (BIDDLE e BERLINER, 2002).

O terceiro tipo de estudos, que em geral necessita de informações detalhadas sobre as opções feitas acerca da alocação dos recursos viabilizados via financiamento, no nível da escola ou até mesmo no nível do aluno, é o mais escasso. A produção de informação sobre o financiamento das escolas, assim como acerca da utilização destes recursos pelas unidades de ensino, é apontada como trabalhosa e dispendiosa (PICUS, 1998). De toda forma, este tipo de 
pesquisa é apontado como essencial para que sejam exploradas possibilidades de alocação e uso dos recursos que contribuam para a melhoria da aprendizagem (PICUS, 2000).

A maior parte dos estudos norte-americanos que se dedicam a explorar diferentes opções de alocação e uso dos recursos escolares (terceiro tipo de estudos) tem sido produzida no contexto do que tem sido chamado de adequacy of funding. Ainda que a questão sobre a desigualdade na distribuição dos recursos não tenha sido superada, o início da década de 1990, nos Estados Unidos, foi marcado pela mudança de foco dos estudos sobre financiamento das escolas, tendo crescido a ênfase na produção de pesquisas e propostas acerca da adequação do financiamento. Mesmo que diferentes possibilidades de entendimento acerca do que seria a adequação do financiamento sejam possíveis, parece predominar a compreensão de que o termo está menos relacionado com a garantia de determinada quantidade de recursos ou insumos do que com os resultados do ensino viabilizado com os recursos disponibilizados. Isto é, ao se delimitar o financiamento que pode ser considerado adequado, o termo adequado geralmente inclui determinado padrão de aprendizagem a ser alcançado pelos alunos, não se referindo somente às condições de oferta do ensino nas escolas (CONLEY e PICUS, 2003, p. 587, PICUS, 2000, p. 77, KIMBAL, 2009, p. 39-44).

A tentativa de delimitar o financiamento que possa ser considerado adequado tem dado origem a quatro tipos de abordagens de pesquisa, também entendidas como quatro diferentes abordagens de mensuração de custos da educação:

1) O Modelo de Função de Custo consiste em abordagem similar à função de produção, mas com uma inversão de variáveis. Neste tipo de modelagem, é estimada uma regressão que tem como variável dependente o gasto por aluno, enquanto o desempenho do aluno entra como uma das variáveis explicativas. Dito de outra forma, a abordagem parece corresponder a uma espécie de "determinantes do gasto por aluno", em que uma das variáveis explicativas para o gasto é o desempenho. Assim, procura-se estabelecer uma medida de gasto para o alcance de determinado desempenho, controlando-se outras variáveis que possam influenciar o gasto, como por exemplo o nível médio de salários de cada região, que podem influenciar o salário a ser pago aos professores das escolas 
consideradas na estimativa. Pesa contra este tipo de estudo o fato de ser baseado em técnica de análise estatística pouco acessível, o que torna a adesão a seus resultados pouco atrativa aos gestores dos sistemas de ensino (CONLEY e PICUS, 2003, p. 588)

2) A Generalização de Custos de Escolas com Desempenho Satisfatório consiste na estimação dos gastos de escolas em que os alunos apresentam bons desempenhos em testes padronizados, com posterior generalização de tais gastos como sendo os adequados às escolas de determinado distrito. Contra esta abordagem, pesa o fato de a estimativa considerada "ótima" não levar em conta os variados perfis de escolas presentes em um distrito (RESCHOVSKY e IMAZEKI, 2000, p. 3).

3) Uma terceira forma de estimar o financiamento que seria adequado para sistemas de ensino e para escolas é através do Julgamento Profissional. Neste caso, é considerada a opinião de um grupo de especialistas sobre quais seriam os recursos necessários para a oferta de um ensino que promova determinado padrão de desempenho. Em geral, a partir da opinião dos especialistas ouvidos, são desenvolvidas "escolas protótipo", que deverão ter certa quantidade e determinado padrão de alocação de recursos, segundo as características dos estudantes a serem atendidos, dos preços locais de bens e serviços e de demais particularidades da região em que se encontra cada escola. A principal crítica a este tipo de abordagem recai sobre a subjetividade do julgamento dos profissionais envolvidos, que podem ter diferentes pontos de vista sobre as estratégias a serem utilizadas para a promoção da melhoria do desempenho dos alunos e dos recursos necessários para viabilização destas (CONLEY e PICUS, 2003, p. 591).

4) Por fim, têm sido produzidos alguns estudos que procuram identificar e descrever, a partir de reformas conduzidas em escolas em que os alunos apresentavam baixo desempenho em testes padronizados, práticas de alocação e uso dos recursos que se mostraram eficazes para a melhoria do desempenho. A análise das mudanças feitas na alocação e no uso dos recursos, no nível das escolas, e das consequências de tais mudanças em termos de desempenho dos alunos, tem contribuído para o avanço do entendimento da relação entre recursos e resultados escolares, sendo útil 
para a passagem do foco de se os recursos importam para como importam (CONLEY e PICUS, 2003, p. 590).

Outra característica comum à maior parte dos estudos que se dedicam a explorar a alocação de recursos escolares no contexto norte-americano, além do foco no desempenho, é a consideração de diferentes necessidades de financiamento, segundo as características dos alunos e do atendimento escolar a ser viabilizado. Em geral, os quatro aspectos recorrentemente citados como motivo para diferenças a serem observadas na destinação de recursos a distritos e escolas são: 1) o atendimento a alunos que apresentam necessidades educacionais especiais; 2) o atendimento a alunos provenientes de famílias de baixo nível socioeconômico; 3) o atendimento a alunos que não dominam o idioma utilizado para o ensino no dia-a-dia da escola e 4) as características dos alunos, das escolas e do mercado de trabalho de cada região que possam afetar o nível de salários a serem pagos aos professores.

Se diferenças de custo entre distritos escolares são substanciais, então a imposição de padrões de desempenho para os estudantes de todo o estado, sem simultaneamente reformar a maneira como os recursos financeiros são distribuídos entre os distritos escolares, resultará em uma situação em que distritos com custos acima da média não terão recursos suficientes para levar seus estudantes a alcançar os novos padrões de desempenho. Estas escolas falharão, não necessariamente por causa de sua própria incapacidade de educar eficazmente seus alunos, mas porque elas foram providas com recursos insuficientes para realizar este trabalho. (RESCHOVSKY e IMAZEKI, 2000, p. 2, tradução nossa) ${ }^{12}$

Em relação ao atendimento de alunos que apresentam necessidades educacionais especiais, Monk, Pijanowski e Hussain (1997, p. 55) apontam que o crescimento deste tipo de atendimento, nos Estados Unidos, tem implicado em aumento dos gastos de distritos e escolas proporcionalmente maior que dos gastos destinados ao ensino regular. De toda forma, os autores apontam a dificuldade de separação, no nível da escola, dos gastos com educação

\footnotetext{
12 Original: "If cost differences among school districts are substantial, then imposing statewide student performance standards without simultaneously reforming the way financial resources are distributed among school districts will result in a situation where school districts with above average costs will not have enough resources to educate their students to meet the new standards. These schools will fail, not necessarily because their own inability to effectively educate children, but because they were provided with insufficient fiscal resources to do the job" (RESCHOVSKY e IMAZEKI, 2000, p. 2).
} 
especial $^{13}$, sobretudo porque o atendimento dos alunos em classes regulares torna difícil a delimitação do esforço e do recurso adicional consumido para o atendimento destes.

Reschovsky e Imazeki (2000), procurando identificar os custos da promoção de níveis de desempenho que possam ser considerados adequados para distritos do Texas e de Wisconsin, apontam que a proporção de alunos que apresentam necessidades educacionais especiais impacta positivamente o custo do atendimento escolar dos distritos de Wisconsin e, adicionalmente, a partir da construção de um índice de custo, concluem que, de forma geral, os distritos que apresentam maiores proporções desta modalidade de atendimento necessitam de mais recursos para que obtenham um padrão de desempenho que possa ser considerado adequado.

Tendo em vista que o atendimento a alunos que apresentam necessidades educacionais especiais pode implicar no consumo de recursos adicionais, pode-se presumir que a exploração da relação entre recursos e desempenho dos alunos, sem a consideração da existência e magnitude deste tipo de atendimento pode levar ao estabelecimento de conclusões equivocadas. Isto é, se duas escolas contam com diferentes proporções de alunos que apresentam necessidades educacionais especiais, possivelmente a que apresenta a maior proporção incorrerá em maiores gastos para a promoção da aprendizagem de seus alunos, sem que isso signifique ineficiência no uso dos recursos.

Lógica semelhante se aplica ao atendimento a alunos provenientes de famílias de baixo nível socioeconômico ou que não falam o idioma local. Os alunos que não dominam o inglês, na maioria das vezes, necessitam de ajuda adicional, o que pode se refletir em recursos adicionais, para que possam acompanhar as atividades escolares em que estão envolvidos. Da mesma forma, considerando que grande parte do desempenho dos alunos é explicado pela sua condição social, muitas vezes os alunos provenientes das famílias mais pobres necessitam de apoio adicional para que possam desenvolver habilidades e competências adequadas à idade e ano escolar em que se encontram. Este apoio adicional geralmente se reflete em alocação de

\footnotetext{
${ }^{13} \mathrm{O}$ termo Educação Especial, no contexto norte-americano, é utilizado para fazer referência a um grupo mais abrangente de alunos, quando comparado ao mesmo termo no Brasil. Em geral, nos Estados Unidos, Educação Especial inclui estudantes com diferentes formas de dificuldade de aprendizagem (NICHCY, 2012). No Brasil, o termo Educação Especial é utilizado para fazer referência ao atendimento educacional especializado aos "educandos com deficiência, transtornos globais do desenvolvimento e altas habilidades ou superdotação", conforme o artigo $4^{\circ}$, inciso III da LDB.
} 
recursos adicionais a alunos ou grupos de alunos nas escolas, notadamente sob a forma de horas adicionais de aulas, treinamento de professores para que atuem em conformidade com as necessidades de aprendizagem destes alunos, ou na composição de menores razões aluno/professor, o que pode ser viabilizado por meio de turmas menores ou de professores auxiliares (SCHWARTZ, RUBENSTEIN e STIEFEL, 2009, ODDEN, 2009).

Novamente nestes casos, a desigualdade de perfil dos alunos entre escolas pode implicar em desigualdade no financiamento destas, sem que tal variação de financiamento entre as escolas signifique algo em termos da variação de desempenho observada. Em um contexto de atendimento conforme as necessidades dos alunos, poderia ser constatada uma relação negativa entre recursos e desempenho, já que os maiores gastos poderiam estar associados às unidades de ensino que atendem a alunos que apresentam os menores níveis de desempenho, em determinado momento. Por outro lado, a disponibilização de uma mesma quantidade e variedade de recursos a escolas que apresentam diferentes necessidades de financiamento pode implicar na falta de recursos, podendo tal carência estar na origem de problemas observados na aprendizagem.

O último fator relacionado às diferenças na demanda por recursos, conforme relatado pela literatura analisada, diz respeito aos fatores a serem considerados na determinação dos salários a serem pagos aos professores e demais profissionais que atuam nas escolas.

Ferguson (1991), investigando os fatores associados ao desempenho dos alunos que residem nos distritos do estado do Texas, procura identificar as características de determinados distritos escolares que estão relacionadas à atração de professores que possam ser considerados efetivos. Para delimitar a efetividade dos professores, o autor considera as características destes que são positivamente associadas ao desempenho dos alunos. Os achados apontaram para a experiência, a formação (realização de pós-graduação) e o desempenho em exames de certificação como características dos professores que impactam positivamente o desempenho dos alunos, sendo destacado o efeito do desempenho em exames de certificação. Delimitadas as características dos professores que podem contribuir para a melhoria do desempenho dos alunos, o autor passa a explorar os determinantes da oferta de professores, na tentativa de identificar as características de escolas e distritos que contribuam para a atração de professores considerados efetivos. 
Os resultados apontam que a oferta de professores varia segundo o salário relativo oferecido pelos distritos, de acordo com o percentual de adultos com formação superior e segundo a proporção de alunos negros, hispânicos, que têm inglês como segundo idioma e que pertencem a famílias provenientes de ambiente rural. Observou-se, assim, que em geral, os professores mais experientes, com melhor pontuação nos exames de certificação e com pósgraduação, tendem a escolher os distritos que oferecem os maiores salários e que tenham a menor proporção de alunos provenientes de famílias que vivem em condições sociais desfavoráveis. Diante do exposto e voltando à questão das diferenças na demanda por recursos para a viabilização de determinado desempenho dos alunos, o autor conclui:

[...] salários iguais não vão atrair professores igualmente qualificados para distritos escolares diferentes: para determinado salário, o professor prefere um distrito escolar com maior nível socioeconômico e considera a atratividade de lecionar em um distrito relativamente a outras oportunidades. Isso sugere que uma política de estado de diferenciação salarial - em que distritos com nível socioeconômico mais baixo pagam salários mais elevados - será necessária se for para cada distrito obter sua parte de melhores professores. (FERGUSON, 1991 , p. 489, tradução nossa) ${ }^{14}$

Abordagens semelhantes à de Ferguson são empreendidas por Chambers (1995) e por Reschovsky e Imazeki (2000), sendo as conclusões similares às obtidas pelo primeiro, o que ressalta a importância da consideração das características dos alunos, escolas e regiões em que estas se encontram, nas decisões sobre o financiamento das escolas, assim como deixa claro o cuidado a ser tomado no estabelecimento de relações entre os gastos por aluno e os resultados obtidos, em termos de desempenho, já que tal exercício pode se tornar frágil sem a consideração das diferentes demandas por recursos para a viabilização da aprendizagem que se pretende.

A avaliação das diferentes necessidades de recursos parece ser o ponto de partida para as decisões acerca da alocação de recursos, sobretudo quando se tem em vista a promoção de determinado nível de aprendizagem para todos os alunos. A informação acerca destas diferentes necessidades, porém, muitas vezes se perde no momento da alocação de recursos,

\footnotetext{
${ }^{14}$ Original: "[...] equal salaries will not attract equally qualified teachers to dissimilar schools districts: for any given salary, teacher prefer school districts with higher socioeconomic status and judge the attractiveness of teaching in a given district against the allure of other opportunities. This suggests that a state policy of salary differentials - where districts with lower socioeconomic status pay higher salaries - will be necessary if each district is to get its proportionate share of the best teachers" (FERGUSON, 1991, p. 489).
} 
pois em geral a classificação utilizada para fins de financiamento ou para apuração dos gastos das escolas não dialoga com as diferentes atividades ali desenvolvidas. Assim, o elo entre o que se faz e o que se gasta para viabilização daquilo que é feito se perde. Notando a necessidade de entender a alocação dos recursos segundo a finalidade dos gastos a serem realizados, para um possível melhor entendimento acerca da relação entre recursos, atividades desenvolvidas e desempenho dos alunos, Picus e Peternick (1998) apontam:

O foco da maioria dos sistemas de finanças de estado está na prestação de contas [de dados] fiscais, e não em entender como ou porque as decisões sobre alocação dos recursos são feitas. Estes sistemas geralmente estão focados em reportar [a execução de] elementos de despesa. Como resultado, nós temos uma boa ideia sobre quanto nossas escolas gastam com salários, benefícios, contratos etc., mas relativamente pouco sobre gastos por função (ensino, administração, serviços [oferecidos] aos alunos, manutenção, transporte etc.), e menos ainda sobre quanto é gasto por programas (programas de formação profissional, programas regulares, e programas especiais para [alunos com] deficiência física ou mental, com problemas emocionais e com dificuldade de aprendizagem).

[...] até que nós possamos identificar estes custos, parece improvável que sejamos capazes de determinar como o uso dos recursos educacionais estão relacionados ao desempenho dos estudantes. (p. 109, tradução nossa) ${ }^{15}$

A longa transcrição acima é útil para indicar que o conhecimento sobre com o que são gastos os recursos viabilizados via financiamento é menos útil do que o conhecimento acerca de para que são gastos tais recursos, quando o objetivo é a compreensão das relações entre gastos e desempenho dos alunos. Esta mudança de foco sugerida por Picus, porém, não implica em avanço significativo se feita em níveis de agregação superior à unidade escolar, já que as atividades financiadas e as consequências destas, em termos de aprendizagem, se dão nas escolas. Dito de outra forma, a execução da despesa de forma agregada (por distrito, por município ou por estado) diz muito pouco sobre o que foi feito, na prática, com os recursos viabilizados, o que torna frágil as tentativas de associação entre financiamento e resultados escolares (PICUS et al, 2008, p. 6).

\footnotetext{
${ }^{15}$ Original: "The focus of most state finance reporting systems is on fiscal accountability, not understanding how or why resource decisions are made. These systems generally focus on object-level reporting. As a result, we know a great deal about how much our schools spend for salaries, benefits, contracts, etc., but relatively little about expenditures by function (instruction, administration, pupil services, maintenance and operations, transportation, etc.), and even less about how much is spent by individual programs (vocational programs, regular programs, and special programs for the mentally retarded, physically handicapped, emotionally disturbed and learning disabled).

[...] until we can identify these costs, it seems unlikely we will be able to ascertain how the use of educational resources is linked to student achievement" (PICUS e PETERNICK, 1998, p. 109).
} 
Neste ponto do trabalho, entendo ser válida uma distinção. Até o momento, os termos uso e alocação de recursos têm sido utilizados sem que seja explicitada a diferença de significados que se pretende atribuir a cada um. Para a análise empreendida neste trabalho, o termo alocação de recursos é utilizado para referências à destinação ou utilização de recursos financeiros para determinado fim. Já o termo uso dos recursos é utilizado para fazer referência às diferentes possibilidades de utilização dos recursos escolares, materializados na forma de espaços, equipamentos, profissionais que atuam nas escolas ${ }^{16}$ etc.

O trabalho anteriormente citado, de Picus e Peternick (1998), constitui um bom exemplo de análise, no nível da escola, acerca de classificações e variáveis a serem observadas, no que diz respeito às opções de alocação e de uso dos recursos, que possam ser úteis para o entendimento das relações entre recursos e desempenho dos alunos. Alinhados ao objetivo de verificar como e não somente quanto as escolas gastam, e de como a alocação e o uso dos recursos podem estar relacionados ao desempenho dos alunos, os autores explicitam a abordagem e os instrumentos de pesquisa utilizados para acompanhar o desenvolvimento acadêmico de vinte e três mil alunos, da pré-escola ao quinto ano, assim como para o acompanhamento dos gastos efetuados e do uso dos recursos disponibilizados durante a trajetória escolar destes alunos.

Em relação às opções feitas em termos de alocação dos recursos, os autores propõem que as despesas efetuadas sejam divididas em quatro grupos, ou níveis: 1) custos no nível sala de aula, correspondentes à remuneração de professores e de professores auxiliares, aos gastos com materiais utilizados para o ensino e às despesas com o oferecimento de atendimento especializado aos alunos portadores de necessidades educacionais especiais e aos que não dominam o idioma local, dentre outras formas de atendimento especializado; 2) custos no nível da escola, correspondentes aos gastos com suporte ao ensino, suporte ao aluno, utilidades, transporte, manutenção e administrativos; 3) custos no nível do distrito, relativos a instalações, processamento de dados e aos gastos administrativos e 4) custos não relacionados à escola, referentes aos gastos efetuados por agências não governamentais e pelos pais.

\footnotetext{
${ }^{16}$ Seja pela especificidade do trabalho desenvolvido, seja pela destacada importância em relação ao processo de ensino-aprendizagem, professores, diretores e demais profissionais que trabalham nas escolas não podem ser restritos à categoria de recursos. De toda forma, considerando que estes profíssionais estão associados a determinado gasto em que incorrem as escolas para o desenvolvimento de suas atividades, as opções feitas em termos de alocação dos profissionais que atuam nas escolas serão tratadas no âmbito da categoria em questão.
} 
Nota-se que a classificação proposta para o acompanhamento do gasto das escolas se distancia das classificações que apontam para elementos de despesa, frequentemente utilizadas em orçamentos públicos, não sendo apontadas, por exemplo, despesas com equipamentos, material de consumo ou material permanente, e sim despesas com suporte ao ensino, suporte ao aluno, etc. Assim, cada categoria proposta agrega gastos associados a variados elementos de despesa.

Se, por um lado, a construção de categorias não atreladas à natureza de despesa ou a classificações contábeis bem delimitadas expõe a classificação proposta à subjetividade de quem a elabora, por outro, categorias que apontem para aquilo que é feito com os recursos financeiros que são utilizados para o desenvolvimento das atividades escolares parecem ser promissoras para o entendimento de como os recursos se relacionam com os resultados associados às atividades financiadas. Isto é, diante do interesse em entender como os recursos podem ser utilizados para a melhoria, por exemplo, da aprendizagem dos alunos, o conhecimento de quanto é gasto com educação especial, com suporte ao ensino ou com materiais utilizados para o ensino parece ter mais a oferecer do que o conhecimento acerca dos gastos com material permanente e de consumo.

Em conjunto com a delimitação das despesas, segundo as categorias citadas, os autores propõem o acompanhamento de uma série de características relacionadas à disponibilidade e ao uso dos recursos disponíveis nas escolas. A sequência de questões sobre livros-texto constitui um bom exemplo do tipo de acompanhamento pretendido: "Quantos livros você usa em suas aulas?; Há disponibilidade de livros para todos os alunos?; Se não, qual é a porcentagem, aproximadamente, de crianças que tem cópias de cada livro usado?" (PICUS e PETERNICK, 1998, p. 114-115, grifo nosso, tradução nossa) ${ }^{17}$. Vale notar que as questões indicadas se preocupam não só com a disponibilidade de livros, mas com a disponibilidade dos livros efetivamente utilizados pelos professores.

As outras questões, distribuídas nos questionários dos professores, professores de educação especial, diretores e pais, vão desde o número de crianças com alguma deficiência em cada turma, o que é relevante para a compreensão acerca da quantidade necessária de recursos

\footnotetext{
${ }^{17}$ Original: "How many different textbooks do you use in your class?; Are there enough of each textbook for each enrolled child?; If no, approximately what percentage of the children in your class have copies of each textbook used?" (PICUS e PETERNICK, 1998, p. 114-115)
} 
específicos para o atendimento a estes alunos, até as condições de espaço, ventilação, temperatura e nível de ruído dos diversos ambientes das escolas (sala de aula, biblioteca, sala de música, sala de artes, banheiros, etc.).

Diante do exposto, é possível perceber que o acompanhamento da alocação e do uso dos recursos, no nível da escola, pode ser bastante trabalhoso. De toda forma, informações que apontem para a disponibilidade e condições de uso de determinados recursos escolares podem ser facilmente viabilizadas, a depender da existência de instrumentos já consolidados para a coleta destes dados. No Brasil, os questionários do professor e do diretor do Sistema de Avaliação da Educação Básica (SAEB), assim como as informações provenientes do Censo Escolar, têm sido úteis para a aquisição de informações sobre a disponibilidade e condições de uso de diversos espaços, equipamentos e materiais presentes nas escolas. Sobre este ponto, uma breve análise dos itens dos questionários do SAEB de 2001 permite que se verifique que os construtos relativos aos recursos das escolas contam com a maioria das questões, relativamente aos demais construtos (FRANCO et al, 2003). Contudo, o estabelecimento de vínculo entre as informações presentes em tais questionários e o financiamento das escolas não parece ser uma tarefa de fácil viabilização pois, em geral, não são fornecidas informações sobre a quantidade dos recursos, assim como nem todos os recursos são mapeados pelos questionários.

Conley e Picus (2003), também tomando a escola como unidade de análise, descrevem o Oregon Quality Education Model (OQEM), modelo proposto para o financiamento das escolas do estado do Óregon que, com base em escolas protótipo, se propõe a prover os recursos financeiros que viabilizem determinada estratégia de alocação e uso dos recursos, com vistas ao alcance de certo padrão de desempenho desejado para os alunos.

O OQEM tem várias características-chave. Primeiro, o modelo é derivado da definição de educação de qualidade [do estado] do Oregon. Segundo, escolas, não distritos, são a unidade de análise. Terceiro, o modelo especifica os elementos-chave e componentes de uma educação de qualidade em detalhamento suficiente para permitir uma análise relativamente refinada dos efeitos de acrescimentos ou decréscimos do financiamento estadual sobre as escolas. Quarto, o modelo considera e aloca todo o orçamento de educação pública, referente ao atendimento de alunos de 4 a 18 anos. Quinto, o modelo pode ser configurado de diferentes maneiras, de forma a refletir diferentes definições de adequação. Sexto, o modelo identifica fatores não monetários que afetam a eficiência de operação das escolas. Sétimo, o modelo estabelece uma relação entre os recursos alocados, programas providos, e resultados 
projetados da aprendizagem dos estudantes. (CONLEY e PICUS, 2003, p. 595-596, tradução nossa) ${ }^{18}$

O modelo proposto e as conclusões a que permite chegar são, aparentemente, menos ambiciosos do que o enunciado. Ainda que a adoção de escolas protótipo permita a análise da relação entre variações no financiamento e variações nos recursos escolares a serem disponibilizados e, consequentemente, no atendimento escolar possível (exercício este facilitado pela produção de informação padronizada sobre gastos no nível das escolas do estado em questão) (p. 592), não é possível, com algum grau de precisão, estabelecer a relação enunciada na sétima característica do modelo. Conforme apontado pelos autores, o estabelecimento da relação entre recursos financeiros a serem disponibilizados e o resultado a ser obtido não está baseado em alguma forma de abordagem estatística, sendo na verdade um “melhor palpite" (p. 605-608).

De toda forma, o trabalho em questão traz proposta de classificação dos gastos das escolas, associada à alocação a ser dada aos recursos viabilizados via financiamento, que merece destaque. As escolas protótipo do modelo em questão, projetadas para refletir uma escola real operando em condições consideradas ótimas em termos de organização e estratégia, e não para refletir a média das práticas e condições existentes (p. 597), tiveram suas despesas classificadas segundo os seguintes elementos: 1) Pessoal envolvido com as atividades de ensino consideradas básicas; 2) Pessoal envolvido com atividades de suporte ao ensino e aos alunos; 3) Administração escolar; 4) Computadores e componentes; 5) Suprimentos, livros e materiais [utilizados para o ensino]; 6) Atividades extracurriculares; 7) Treinamento e desenvolvimento profissional; 8) Atividades de reforço escolar; 9) Custos centralizados, referentes a atividades de suporte às escolas (envolvem, por exemplo, transporte dos alunos, alimentação escolar e serviços de manutenção); e 10) Despesas administrativas do distrito (CONLEY e PICUS, 2003, p. 598-600)

\footnotetext{
${ }^{18}$ Original: "The OQEM has several key characteristics. First, the model is derived from Oregon's definition of a quality education. Second, schools, not districts, are the unit of analysis. Third, the model specifies the key elements and components of a quality education in enough detail to allow for relatively fine-grained distinctions about the effects on schools of increases or decreases in state funding. Fourth, the model captures and allocates the entire K-12 education budget. Fifth, the model can be configured in various ways to define adequacy in different ways. Sixth, the model identifies nonmonetary factors that affect the efficiency with which schools are assumed to be operating. Seventh, the model establishes a relationship between the resources allocated, programs provided, and projected student-learning outcome" (CONLEY e PICUS, 2003, p. 595-596).
} 
A classificação proposta, que difere da utilizada por Picus e Peternick (1998), não é menos útil para elucidar as múltiplas finalidades dos gastos efetuados pelas escolas. Nota-se que no trabalho de 2003, os autores optam por não dividir os recursos segundo os níveis de atividades desenvolvidas nas escolas, sendo possível que diferentes categorias agreguem gastos que ocorrem, por exemplo, no nível da sala de aula (como no caso das categorias Pessoal envolvido com as atividades de ensino consideradas básicas e Suprimentos, livros e materiais).

Em conjunto com as categorias de atividades e funções a serem financiadas, são apresentadas algumas das estratégias de uso dos recursos que devem ser suportadas pelo OQEM. Para a implementação completa do modelo, que teria como propósito garantir que $90 \%$ dos alunos do estado do Óregon atingissem ou superassem resultados considerados satisfatórios, são exemplos de medidas a serem implementadas/financiadas: 1) reduzir as turmas do primeiro ao terceiro ano a 20 alunos; 2) reduzir as turmas do quarto e do quinto ano a 24 alunos; 3 ) permitir a contratação de mais professores especialistas (professores de artes, música, educação física etc.); 4) viabilizar o aumento do tempo dedicado ao desenvolvimento profissional; 5) viabilizar o adequado financiamento da manutenção das escolas, de modo a não serem desviados recursos relacionados ao ensino para as atividades de manutenção; 6) prover tempo adicional de ensino para $20 \%$ dos estudantes; 7 ) chegar a uma proporção de seis estudantes por computador.

Como é possível perceber, nos estudos dedicados ao exame dos gastos no nível das escolas, parece haver uma tendência em, por um lado, serem utilizadas categorias de gastos que tenham relação com as atividades ou funções a serem desempenhadas pelas escolas e, por outro, ser acompanhado um conjunto de estratégias de uso dos recursos que possam ser, de alguma maneira, relacionadas ao resultado pretendido. Isto é, de diferentes formas, os dois trabalhos citados associam categorias de gastos a medidas que indicam a disponibilidade ou o uso dos recursos pelas escolas, tendo em vista determinado resultado a ser obtido.

Odden et al (2003) apresentam proposta de análise dos gastos das escolas em que a associação entre estrutura de gastos e indicadores que apontem para o uso feito dos recursos é, explicitamente, a abordagem escolhida. O objetivo do trabalho é " [...] criar uma estrutura de relatórios fiscais no nível da escola que informe o uso dos recursos escolares e que, 
simultaneamente, indique tanto quanto possível a estratégia educacional que essas práticas de uso dos recursos refletem" (p. 327, tradução nossa) ${ }^{19}$.

É válido apontar que, ainda que a intenção dos autores não seja a análise de relações entre alocação e uso dos recursos e resultados, as categorias de gasto e os indicadores de recursos propostos estão alinhados a estratégias e atividades a serem implementadas que suportariam resultados positivos, em termos de desempenho dos alunos. Dito de outra forma, as categorias escolhidas para gastos e indicadores refletem aquilo que já se sabia que poderia ter efeito sobre o resultado, com base em experiências prévias de análise da alocação e uso dos recursos em escolas que apresentam bons desempenhos (p. 327). Se, por um lado, esta opção é promissora no sentido de viabilizar análises sobre a relação entre recursos e desempenho, por outro, a implementação da estrutura proposta poderia induzir à destinação de menos recursos para atividades escolares que não estejam relacionadas ao resultado dos alunos em testes.

Os indicadores de recursos e a estrutura proposta para os gastos que, de acordo com os autores, podem ser bons instrumentos para a comparação da alocação e uso de recursos entre diferentes escolas, são indicados nas Tabelas 4 e 5 (as tabelas originais encontram-se nos anexos A e B, respectivamente).

\footnotetext{
${ }^{19}$ Original: "[...] to create a school-level, fiscal reporting structure that reports school-level resource use and simultaneously indicates as much as possible about the educational strategy those resource-use practices reflect" (ODDEN et al 2003, p. 327).
} 
TABELA 4 - PROPOSTA DE INDICADORES DE RECURSOS ESCOLARES ${ }^{20}$

\begin{tabular}{|c|c|}
\hline $\begin{array}{l}\text { Indicadores relacionados à necessidade de } \\
\text { recursos }\end{array}$ & Indicadores relacionados ao uso dos recursos \\
\hline 1. Tamanho da escola & 8. Tempo de aula por dia \\
\hline 2. Tamanho da unidade escolar & 9. Duração das aulas (em minutos) \\
\hline 3. Percentual de alunos de baixa renda & $\begin{array}{l}\text { 10. Duração das aulas de leitura (alunos de } 4 \text { a } 11 \\
\text { anos) }\end{array}$ \\
\hline 4. Percentual de alunos de educação especial & $\begin{array}{l}\text { 11. Duração das aulas de matemática (alunos de } 4 \\
\text { a } 11 \text { anos) }\end{array}$ \\
\hline $\begin{array}{l}\text { 5. Percentual de alunos cujo inglês não é a língua } \\
\text { materna ou que não são proficientes em inglês }\end{array}$ & $\begin{array}{l}\text { 12. Tamanho das turmas de leitura (alunos de } 4 \text { a } \\
11 \text { anos) } \\
\text { 13. Tamanho das turmas de matemática (alunos } \\
\text { de } 4 \text { a } 11 \text { anos) }\end{array}$ \\
\hline Indicadores relacionados a gastos & $\begin{array}{l}\text { 14. Tamanho das turmas regulares (alunos de } 4 \text { a } \\
11 \text { anos) }\end{array}$ \\
\hline 6. Gastos por aluno & $\begin{array}{l}\text { 15. Duração das aulas das matérias consideradas } \\
\text { básicas* (14 a } 18 \text { anos) }\end{array}$ \\
\hline $\begin{array}{l}\text { 7. Desenvolvimento profissional (gastos por } \\
\text { professor) }\end{array}$ & $\begin{array}{l}\text { 16. Tamanho das turmas das matérias } \\
\text { consideradas básicas ( } 14 \text { a } 18 \text { anos) } \\
\text { 17. Tamanho das turmas das matérias não } \\
\text { consideradas básicas ( } 14 \text { a } 18 \text { anos) } \\
\text { 18. Percentual de professores das matérias } \\
\text { consideradas básicas }\end{array}$ \\
\hline
\end{tabular}

FONTE: ODDEN et al, 2003, p. 330.

*Math, English/LA, Science, \& Social Studies.

Como é possível notar, os cinco primeiros indicadores captam, de alguma forma, as diferentes necessidades de recursos por parte das escolas, seja devido ao tamanho destas, seja devido à proporção de alunos de baixa renda, de educação especial ou que necessitem de apoio adicional relacionado ao idioma. O gasto total por aluno seria uma espécie de medida da disponibilidade total de recursos e os demais indicadores apontariam para as opções feitas acerca do uso dos recursos disponibilizados. Este conjunto de indicadores, como defendem os autores, seria relevante para a identificação das estratégias das escolas em relação aos recursos a elas disponibilizados e para a comparação de tais estratégias.

Em relação à classificação adotada para os gastos, os autores incorporam, em parte, as categorias já utilizadas pelo National Center for Education Statistics (NCES), no que diz

\footnotetext{
${ }^{20}$ A divisão dos indicadores segundo as categorias apresentadas não consta na proposta dos autores. Assim, na tabela original todos os indicadores listados pertenciam à categoria única "indicadores de recursos".
} 
respeito à classificação por funções (ensino, suporte ao ensino, suporte ao aluno, administração, transporte de alunos e alimentação, dentre outras), assim como a classificação por programas (educação especial, educação bilíngue e apoio educacional a alunos de baixa renda, dentre outros), utilizada em diversos contextos. De toda forma, a estrutura adotada corresponde a um arranjo próprio destas classificações e incorpora determinados "serviços" que devem ser destacados, assim como os gastos que os suportam. Desta forma, em linha com o que se pretende, os autores separam os gastos em duas grandes categorias: gastos com ensino e gastos não relacionados ao ensino (p. 331). 
TABELA 5 - PROPOSTA DE ESTRUTURA DE GASTOS ESCOLARES

Ensino

\section{Currículo Básico}

Professores de Inglês/ Leitura/ Language Arts (literatura, redação e gramática)

História/ Estudos Sociais

Matemática

Ciência

\section{Professores especialistas/Planejamento}

Artes, música, educação física etc.

Vocational (orientação e preparação para o trabalho)

Educação para o trânsito

Bibliotecários

\section{Ajuda extra}

Tutores

Extra Help Laboratories (espaços com computadores e professores disponíveis para ajuda extra aos alunos, fora do período de aula)

Sala de recursos

Professores de inclusão (atua junto aos alunos de educação especial em turmas regulares)

Turmas para alunos cujo inglês não é a língua materna

Turmas de educação especial para alunos com nível severo de deficiência

Período de aula estendido e cursos de férias

\section{Desenvolvimento Profissional}

Pagamento de professores substitutos e de bolsas

Contratação de profissionais que atuam com formação de professores

Administração

Materiais, equipamentos e instalações

Viagens e transporte

Pagamento de taxas e mensalidades de cursos

5. Profissionais relacionados ao ensino que atuam fora de sala de aula

Coordenadores e Teachers on Special Assignment (professores atuando em programas

pedagógicos da escola, em apoio à coordenação e a outros professores)

Funcionários substitutos

Assistentes de apoio ao ensino (monitores)

6. Materiais e equipamentos utilizados para o ensino

Suprimentos, materiais e equipamentos

Computadores (hardware, software, periféricos)

\section{Suporte aos alunos}

Conselheiros

Enfermeiros

Psicólogos

Assistentes sociais

Atividades extracurriculares e Atletismo

\begin{tabular}{l}
\hline Não relacionado ao ensino \\
\hline 8. Administração \\
9. Operações e Manutenção \\
Limpeza \\
Utilidades (água, luz, telefone etc.) \\
Segurança \\
Alimentação \\
\hline FONTE: ODDEN et al, 2003, p. 330.
\end{tabular}


Com o intuito de aplicar a estrutura proposta, a pesquisa em questão seleciona quatro escolas, duas que atendem alunos de 4 a 11 anos de idade e duas que atendem alunos de 14 a 18 anos, a fim de compará-las e verificar em que medida as estratégias de alocação e uso dos recursos podem ser diferenciadas, tendo em vista sobretudo o perfil e o momento pelo qual passam as escolas. Considerando o interesse desta dissertação, são relatados a seguir os resultados relativos às escolas que atendem os alunos de 4 a 11 anos.

Uma das escolas, que atende grande proporção de alunos provenientes de famílias de baixa renda, passou por um processo de reestruturação em sua forma de atuar, assim como em seu financiamento, com o intuito de que seus alunos obtivessem melhorias de desempenho. Assim, esta escola, que já contava com recursos acima da média, devido ao perfil socioeconômico de seus alunos, passou a receber recursos específicos para a implementação de estratégias como redução de turmas e desenvolvimento profissional. A segunda escola, que atende pequena proporção de alunos de baixa renda e apresenta, em média, alto desempenho, conta com menos recursos por aluno para a execução de suas atividades e não passou por um processo de reestruturação que impactasse seus gastos ou suas opções de alocação e uso dos recursos. A Tabela 6 traz os indicadores de recursos, que apontam para as diferenças de estratégia no uso dos recursos.

Ao que parece, a estratégia adotada pela escola que necessita obter melhorias no desempenho de seus alunos passa por forte investimento em desenvolvimento profissional, redução do tamanho de turmas e extensão do tempo para as aulas de leitura. Tal estratégia é confirmada pela estrutura de gastos, que indica maiores gastos desta escola, por aluno, com remuneração de professores do currículo considerado central, com desenvolvimento profissional e com suporte aos alunos, relativamente à escola que já atingiu resultados considerados satisfatórios (p. 339). 
TABELA 6 - INDICADORES DE RECURSOS ESCOLARES PARA DUAS ESCOLAS NORTEAMERICANAS

\begin{tabular}{l|cc}
\hline Indicadores relacionados à necessidade de recursos & Elm Street* & Maple View** \\
\hline Tamanho da escola (matrículas) & 400 & 454 \\
Tamanho da unidade escolar (matrículas) & 400 & 454 \\
Percentual de alunos de baixa renda & $100 \%$ & $38 \%$ \\
Percentual de alunos de educação especial & $15 \%$ & $12 \%$ \\
Percentual de alunos cujo inglês não é a língua materna & $0 \%$ & $0 \%$ \\
ou que não são proficientes em inglês & Elm Street & Maple View \\
\hline Indicadores relacionados a gastos & USD 8.158 & USD 5.369 \\
\hline Gastos por aluno & USD 8.640 & USD 2.038 \\
Desenvolvimento profissional (gastos por professor) & Elm Street & Maple View \\
\hline Indicadores relacionados ao uso dos recursos & 390 & 360 \\
\hline Tempo de aula por dia (minutos) & 40 & 40 \\
Duração das aulas (minutos) & 90 & 60 \\
Duração das aulas de leitura (minutos) & 40 & 90 \\
Duração das aulas de matemática (minutos) & $13-24$ & 12 \\
Tamanho das turmas de leitura & $13-24$ & 24 \\
Tamanho das turmas de matemática & $13-24$ & 24 \\
Tamanho das turmas regulares & $61 \%$ & $77 \%$ \\
Percentual de professores das matérias consideradas & & \\
básicas & $61 \%$ & \\
\hline FONTE: ODDEN al 2003, 336. & & 24 \\
\hline
\end{tabular}

FONTE: ODDEN et al, 2003, p. 336.

*Nome fictício da escola que atende maior proporção de alunos de baixa renda.

**Nome fictício da escola que atende menor proporção de alunos de baixa renda.

Ainda que o trabalho em questão forneça relevante esquema para análise dos gastos e do uso dos recursos de escolas, ele não aponta as consequências, em termos do desempenho dos alunos, das diferentes estratégias de tratamento dado aos recursos. O registro de como foram utilizados os recursos apontam para estratégias que visam determinado resultado, mas não há relato acerca dos resultados.

A estrutura de gastos e de indicadores proposta por Odden et al (2003) foi utilizada por Picus et al (2008) para a análise da alocação e do uso dos recursos de 334 (de um total de 362) escolas de Wyoming, em um esforço de verificar se as estratégias para a promoção da melhoria do desempenho dos alunos estavam sendo implementadas de acordo com o pretendido, ao menos em relação à abordagem delineada para a alocação e o uso dos recursos nas escolas. 
A análise empreendida pelos pesquisadores ocorreu no âmbito da reforma promovida no financiamento das escolas de Wyoming, implementada no contexto das reformas que visavam a adequação do financiamento com base em determinações originadas na esfera do poder judiciário norte-americano. O processo de adequação do financiamento, iniciado em 1997, baseou-se primeiramente na adoção de escolas protótipo, modelo que previa a quantidade de recursos a ser destinada às escolas do estado de acordo com as características das escolas e com as melhorias pretendidas no atendimento aos alunos. No ano de 2006, o modelo passou por uma revisão de seus parâmetros, de forma que a melhoria a ser atingida pelas escolas passou a basear-se em um conjunto de estratégias de alocação e uso dos recursos que, de acordo com estudos conduzidos sobre o tema, contribuiria para a melhoria do desempenho dos alunos. Esta revisão dos parâmetros resultou em um modelo que deveria suportar gastos alinhados à seguinte abordagem:

[...] turmas pequenas em todas as escolas [tanto para as que atendem alunos de 4 a 11 anos, quanto para as que atendem os alunos de 12 a 18 anos], professores especialistas de artes, música e educação física e disponibilização de tempo para planejamento e trabalho conjunto dos professores; um conjunto de estratégias para ajudar os estudantes com dificuldades de aprendizagem, incluindo recursos para tutoria, período diário de aulas estendido, cursos de férias [para melhoria da aprendizagem em conteúdos que foram trabalhados durante o período regular de aulas] e pessoal adicional para suporte aos alunos; estratégia de desenvolvimento profissional, que inclui educadores facilitadores [profissionais que atuam com treinamento e desenvolvimento profissional dos professores], recursos para pagar os professores para que se dediquem a planejamento e treinamento durante as férias e fundos para contratação de consultores e aquisição de materiais de pesquisa; outros recursos educacionais para apoiar a aprendizagem dos alunos. (PICUS et al, 2008 , p. 3, tradução nossa) ${ }^{21}$

A análise da alocação e do uso dos recursos, feita com base no esquema de indicadores e estrutura de gastos propostos por Odden et al (2003) indicaram que, na prática, as escolas tenderam a não aderir à estratégia definida. $\mathrm{O}$ modelo não previa, por exemplo, gastos com professores auxiliares (tradicionalmente contratados pelas escolas), mas previa determinado

\footnotetext{
${ }^{21}$ Original: “[...] strategies for small class sizes in all elementary and secondary schools, teacher specialists to provide programs in art, music and physical education and allow for planning and collaboration time for teachers; a set of strategies to help students who are struggling in the regular education program including tutoring resources, extended day and summer school programs and additional pupil support personnel; a comprehensive professional development strategy that includes instructional facilitators, resources to pay teachers for intensive summer planning and training institutes and funds to purchase other professional development resources such as consultants and research materials; and, other educational resources to support student learning" (PICUS et al, 2008, p. 3).
} 
gasto com a contratação de tutores, de acordo com o número de estudantes considerados em situação de risco em relação à aprendizagem. Os resultados apontaram que, em média, as escolas contrataram menos tutores que o previsto e realizaram gastos substanciais com a contratação de professores auxiliares, estratégia que destoa do que o modelo consideraria adequado para a promoção da melhoria do desempenho dos alunos. A contratação de professores de matérias consideradas centrais também foi, sobretudo nas escolas com maior número de alunos, menor que a prevista. De forma geral, a conclusão acerca das práticas de alocação e uso dos recursos indicou que a estratégia das escolas para a promoção da melhoria do desempenho dos alunos difere da estratégia que sustenta o modelo de financiamento delas, sendo possível notar que, em alguns casos, "[...] mais recursos foram alocados para áreas não relacionadas às atividades de ensino do que o recomendado pelo modelo" (PICUS et al, 2008, p. 27 , tradução nossa) $)^{22}$.

Por fim, os dados agregados de gastos com educação do estado de Wyoming indicam que praticamente não houve variação na proporção dos gastos, segundo a classificação por funções $^{23}$, após a implementação do modelo em questão. Conforme sugerido por Picus (1995) e por Monk (1997), há certa tendência de manutenção dos padrões de gasto entre as diferentes funções relacionadas às despesas com educação nos Estados Unidos, de forma que mesmo o aporte de recursos adicionais acaba sendo distribuído segundo o padrão pré-existente. Para Picus (1995), "Esses achados sugerem que o efeito do recurso adicional sobre o desempenho do aluno pode ser limitado pelo fato dos novos recursos serem utilizados da mesma forma que os recursos já existentes, o que restringe a eficácia potencial desses novos recursos” (p. 18, tradução nossa) $)^{24}$.

Desta forma, ao que parece, o desvio da alocação e do uso dos recursos em relação ao pretendido pelo modelo implementado em Wyoming pode levar ao desvio em relação aos resultados pretendidos, em termos de melhoria do desempenho dos alunos. Tal conclusão, porém, não deve ser entendida como estritamente negativa, considerando que a alocação e o

\footnotetext{
${ }^{22}$ Original: "[...] more resources were generally allocated to areas outside of the classroom and instruction functions than allocated by the model" (PICUS et al, 2008, p. 27).

${ }^{23}$ As categorias de gastos por função, utilizadas para a análise da proporção de gastos por função, foram: ensino, suporte ao estudante, suporte ao ensino, administração escolar, administração central, operações, manutenção, transporte, alimentação, outros.

${ }^{24}$ Original: "These findings suggest that the effectiveness of new money on student achievement may be limited by the fact that these new resources are used in the same way as existing resources, limiting the potential effectiveness of those new dollars" (PICUS, 1995, p. 18).
} 
uso dos recursos se dá em meio a disputas, interesses e de acordo com finalidades que não são necessariamente negativas ou ilegítimas.

As experiências de análise da alocação e do uso dos recursos que, utilizando dados no nível da escola, procuram explorar não somente se os recursos importam, mas como eles podem adquirir relevância para a promoção do aprendizado, através da observação de categorias de gastos e de opções de utilização dos recursos nas escolas que sejam úteis para apontar as diferentes finalidades ou estratégias associadas aos recursos viabilizados via financiamento, têm sido menos férteis no que diz respeito ao relato dos resultados do que em relação à divulgação de propostas, abordagens e instrumentos de coleta e análise de dados relativos aos recursos ou aos gastos escolares.

Odden (2007), relatando a evolução da pesquisa sobre alocação e uso dos recursos empreendida no âmbito do grupo de pesquisadores do Consortium for Policy Research in Education (CPRE), ligado à Universidade de Wisconsin-Madison, grupo este responsável por parte considerável da produção de trabalhos sobre o tema e cujos autores foram, em boa medida, citados nesta pesquisa, aponta que a verificação do que funciona, de fato, nas experiências conduzidas sobre a adequação do financiamento, é o último passo da produção científica sobre o tema (p. 23).

Em um dos trabalhos que procuram mensurar os efeitos de mudanças implementadas no financiamento, Chaudhary (2009), utilizando dados no nível dos distritos, estima os efeitos da reforma do financiamento promovida no estado de Michigan, em 1993. Em uma primeira abordagem a autora estima o impacto do aumento dos gastos, dirigido sobretudo às escolas de distritos de baixa renda, sobre a disponibilidade de recursos escolares. Os resultados permitem observar que a variação no financiamento dos distritos se traduziu essencialmente em aumento dos salários de professores e redução do tamanho das turmas. Após a verificação de como o aumento de gastos se traduziu em aumento da disponibilidade de recursos nas escolas, são estimados os efeitos da variação dos gastos sobre o desempenho dos alunos. Utilizando metodologia apropriada para a identificação de relação causal entre gastos e desempenho, a autora aponta que o aumento do gasto teve efeito positivo e significante sobre as notas em matemática dos alunos do $4^{\circ}$ ano, mas não sobre as notas dos alunos do $7^{\circ}$ ano. Os resultados indicam que o efeito positivo está ligado ao aumento dos salários dos professores, mas não à 
redução do tamanho das turmas, ficando a sugestão de que os salários podem ser uma espécie de proxy para a qualidade dos professores.

A pesquisa empreendida em Michigan, ainda que útil para a compreensão da relação entre gastos e desempenho, é restrita, já que foi feita com base em dados de distritos e não de escolas. Procurando superar esta questão, Archibald (2006) utiliza dados sobre gastos de 53 escolas de ensino fundamental de um distrito da cidade de Reno, Nevada, para mensurar a relação entre recursos e desempenho dos alunos. Utilizando um modelo hierárquico linear de três níveis (aluno, sala de aula e escola) e controlando variáveis de contexto dos alunos e das escolas, a autora explora a relação entre desempenho e os gastos com ensino ${ }^{25}$, suporte ao ensino $^{26}$, liderança/chefia ${ }^{27}$ e operações e manutenção ${ }^{28}$. Ainda que estas categorias, utilizadas pelo Departamento de Educação do estado de Nevada à época, agreguem gastos que poderiam ser melhor detalhados, apontando de forma mais clara para a finalidade do recurso dispendido, elas são úteis, em alguma medida, por informarem os gastos não segundo os elementos de despesa, mas sim em linha com a classificação por funções, que tende a trazer algum indício acerca dos propósitos dos gastos efetuados.

Os resultados da pesquisa indicaram efeitos positivos e estatisticamente significantes do gasto total por aluno sobre o desempenho dos alunos em testes de leitura. Em relação às categorias de gasto consideradas, os achados apontam efeitos positivos e significantes dos gastos por aluno com ensino e com suporte ao ensino. Sobre os resultados e, destacando a relevância da utilização de dados sobre gastos por aluno no nível das escolas, a autora indica que: "O fato

25 "Isso inclui financiamento para professores, professores substitutos, profissionais de apoio ao ensino, tecnologia da informação para uso dos alunos, materiais utilizados para o ensino, viagens, e suprimentos" (p. 40, tradução nossa). Original: "This includes funding for instructional teachers, substitute teacher, instructional paraprofessionals, pupil-use technology, software, instructional materials, trips, and supplies".

26 "Isso inclui financiamento para orientação e aconselhamento, bibliotecas e mídia, atividades extracurriculares, serviços de saúde para os alunos, desenvolvimento do currículo, desenvolvimento professional [da equipe escolar], licenças, gestão de programas [escolares], terapeutas, psicólogos, avaliadores, e assistentes sociais" (p. 40, tradução nossa). Original: "This includes funding for guidance and counseling, libraries and media, extracurricular activities, student health services, curriculum development, staff development, sabbaticals, program management, therapists, psychologists, evaluators, personal attendants, and social workers".

27 "Isso inclui financiamento para diretores, vice-diretores, suporte administrativo, deputados, administradores seniors, pesquisadores, avaliadores de programas, superintendents, representantes do conselho escolar, e equipe jurídica" (p. 40, tradução nossa). Original: "This includes funding for principals, assistant principals, administrative support, deputies, senior administrators, researchers, program evaluators, superintendents, school board representatives, and legal staff".

28 "Isso inclui financiamento para transporte, alimentação, segurança, conservação do prédio escolar, utilidades (água, luz, telefone etc.), manutenção, processamento de dados, e despesas administrativas gerais" (p. 40, tradução nossa). Original: "This includes funding for transportation, food service, safety, building upkeep, utilities, building maintenance, data processing, and business operations". 
deste modelo utilizar dados de gasto por aluno no nível da escola, nesta estrutura de níveis, indica que esta estimativa de efeito dos recursos sobre o desempenho é melhor do que a de muitos estudos anteriores, que usaram dados agregados no nível do distrito" (Archibald, 2006, p. 34, tradução nossa $)^{29}$.

A despeito das diferentes classificações utilizadas, que podem incluir ou excluir e agregar ou desagregar determinados gastos com a categoria que tem sido chamada de ensino, pode-se dizer que a variação dos gastos que suportam atividades diretamente relacionadas ao ensino parece ser relevante para a explicação da variação do desempenho dos alunos. Ainda que para gastos no nível do distrito, Ferguson (1991) encontra resultados semelhantes aos de Archibald, apontando que as conclusões obtidas seriam, de fato, esperadas: "Obviamente, o dinheiro que as escolas gastam diretamente com ensino - com professores e equipamentos utilizados para o ensino - é a despesa que deveria ter a relação empírica mais forte com o desempenho dos alunos em testes" (FERGUSON, p. 485, tradução nossa) ${ }^{30}$, ou dito de outra forma, "O dinheiro importa quando aquilo que ele viabiliza, em termos de insumos escolares, importa" (idem, p. 483, tradução nossa) ${ }^{31}$.

\footnotetext{
${ }^{29}$ Original: "The fact that this model used a school-level per-pupil spending number in this nested structure means that it is a better estimate of the effect of resources on achievement than many previous studies that used data aggregated to the district level" (Archibald, 2006, p. 34).

${ }^{30}$ Original: "Obviously, money that schools spend directly for instruction - for teacher and instructional equipment - is the expenditure that should have the strongest empirical relationship to test scores" (FERGUSON, 1991, p. 485).

${ }^{31}$ Original: "Money matters when the real inputs that it purchases matter" (FERGUSON, 1991, p. 483).
} 


\section{Gastos e desempenho escolar na rede municipal de São Bernardo do Campo: uma análise no nível da escola}

Conforme delineado nos capítulos anteriores, é possível entender que a exploração da relação entre gastos escolares e desempenho dos alunos é restrita quando baseada em informações agregadas no nível municipal. Isso se dá tanto por causa da agregação em si, quanto pela dificuldade de entender as diferentes possibilidades de alocação dos recursos, segundo as finalidades de atendimento escolar que estes recursos representam.

Em linha com o objetivo desta pesquisa e com base na revisão bibliográfica empreendida, este capítulo trata da descrição e análise de dados sobre gastos no nível da escola e da relação entre gastos e o desempenho dos alunos, para uma rede de ensino municipal de médio porte. Para isso, primeiramente, será apresentada proposta de classificação dos gastos escolares que esteja em linha com as funções e atividades escolares das escolas da rede municipal de ensino que forneceu os dados, viabilizando esta pesquisa. Em seguida, são descritos e analisados os dados obtidos e, por fim, são apresentados os resultados das estimativas que relacionam gastos e desempenho.

Como será visto a seguir, as informações obtidas são referentes aos salários dos professores, diretores e coordenadores, dentre outros profissionais que atuam nas escolas. Como o dado referente a salário é componente comum à informação de custo e de despesa ou gasto público, a opção foi utilizar o termo gasto ou despesa por aluno para fazer referência às informações trabalhadas nas próximas seções. Alternativamente, poderia se falar na parcela do custo referente aos salários dos profissionais considerados no levantamento de dados.

\subsection{Proposta de classificação dos gastos escolares para a rede municipal de ensino de São Bernardo do Campo}

Para a realização desta pesquisa era imprescindível que fossem obtidos dados de uma rede de ensino que 1) tivesse porte médio ou grande, o que viabilizaria uma análise quantitativa; 2) que organizasse os dados de forma que fosse possível obter gastos para cada escola da rede; 3) que aceitasse disponibilizar os dados solicitados e 4) que fosse próxima à cidade de São Paulo, o que facilitaria o contato e a realização de reuniões para tratar da pesquisa. Diante 
destes critérios, foi iniciado contato com a Secretaria de Educação de São Bernardo do Campo $^{32}$. Este contato foi facilitado pelo fato do orientador desta pesquisa ter desenvolvido atividades com pessoas que trabalham na referida secretaria.

O trabalho junto à rede municipal de São Bernardo do Campo consistiu na realização de duas reuniões com funcionários da secretaria de educação e troca de informações por email, além de uma reunião com uma diretora de uma das escolas da rede. O contato com a Secretaria de Educação foi essencial para a delimitação das informações sobre gastos que poderiam ser construídas no nível das unidades de ensino (já que a execução do orçamento da Secretaria não se dá por escola, mas de forma agregada), assim como para a compreensão da correspondência entre os gastos empreendidos e a as atividades escolares viabilizadas por tais gastos. Já o contato com a diretora de uma das escolas foi importante para uma melhor compreensão acerca da parte dos gastos realizados diretamente pelas escolas, assim como das atividades associadas a estes gastos.

O levantamento de dados acerca dos gastos escolares, com boa precisão para cada escola da rede, foi possível apenas para as despesas relativas aos salários dos profissionais que atuam nas unidades de ensino. Ainda que sejam dados referentes a uma única categoria de despesa, pode-se dizer que os gastos com salários tendem a representar a maior parte das despesas escolares, considerada a informação sobre a proporção dos gastos com pessoal em relação ao total de despesas, conforme apontado no primeiro capítulo deste trabalho.

Apesar de não ter sido viável o mapeamento de todos os recursos escolares, por escola, no momento da realização desta pesquisa, foi possível elaborar, a partir do diálogo com a Secretaria da Educação de São Bernardo do Campo, uma proposta de classificação dos gastos escolares que desse conta da maior parte dos recursos disponibilizados às escolas. Assim, com base na informação obtida nas reuniões e documentos e tomando como referência classificações para os gastos escolares que apontem, em alguma medida, para a finalidade dos gastos, foi elaborada uma proposta de classificação de gastos escolares, conforme consta na Tabela 7. As categorias propostas tomam como base algumas das classificações propostas pela literatura norte-americana, conforme visto no segundo capítulo, sendo adaptadas para o contexto da rede de ensino em questão. Além do alinhamento ao contexto de São Bernardo do

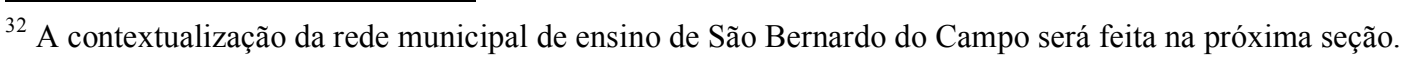


Campo, a classificação proposta guarda correspondência com os anos iniciais do ensino fundamental, já que o interesse em explorar a relação entre gastos e desempenho dos alunos recai sobre esta etapa do ensino.

Como apontado, esta proposta de classificação dos gastos escolares é compatível com as despesas existentes nas escolas, ainda que muitas destas despesas não tenham sido mapeadas, por unidade de ensino, no momento da realização desta pesquisa. De toda forma, é válida como referência para categorias de gastos, conforme as atividades desempenhadas e em linha com a finalidade dos gastos empreendidos. Além disso, as categorias indicadas na tabela dizem respeito ao que foi possível mapear acerca dos recursos escolares a partir dos contatos estabelecidos. Sendo assim, constituem um caminho possível para a classificação dos gastos, mas não representam uma lista exaustiva do que pode ser encontrado, em termos de recursos, em uma escola da rede municipal de São Bernardo do Campo. Por exemplo, é possível que as escolas contem com espaços e materiais destinados a atividades lúdicas, o que não foi considerado nas categorias elencadas.

Os principais agrupamentos de despesas, conforme indicados, guardam relação com a classificação de gastos proposta por Odden et al (2003). Contudo, ao invés de fazer referência a gastos com ensino e não relativos ao ensino, a opção foi classificar os gastos escolares em direta e indiretamente relacionados ao ensino, supondo que todas as atividades desenvolvidas nas escolas estão, de alguma forma, relacionadas ao ensino, podendo ter reflexo sobre a aprendizagem dos alunos. 
TABELA 7 - PROPOSTA DE CATEGORIAS DE GASTOS PARA A REDE MUNICIPAL DE SÃO BERNARDO DO CAMPO

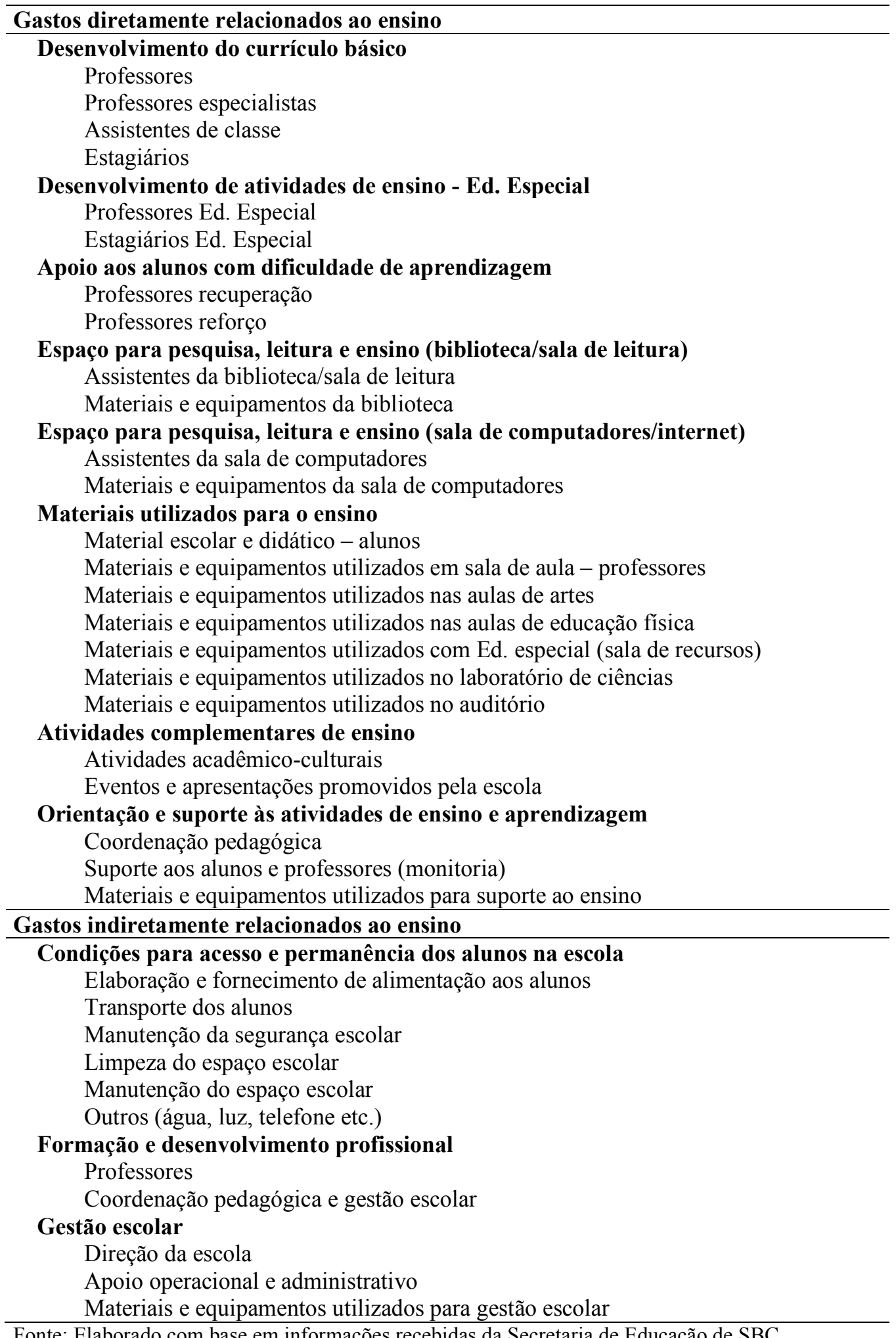


Dentre as categorias diretamente relacionadas ao ensino, a tentativa foi agrupar os gastos em subcategorias que apontem, de alguma forma, para as funções ou atividades desempenhadas pelas escolas. Em alguns casos, deve ser tomado o cuidado para que não ocorra sobreposição dos gastos de diferentes categorias. Por exemplo, nas Atividades complementares de ensino não poderiam ser considerados os salários de professores ou de outros profissionais que atuam nas escolas que estejam envolvidos com tais atividades, já que estes gastos são considerados em outras categorias. Assim, só seriam incluídas nessa categoria as despesas com transporte, alimentação e com pessoas contratadas exclusivamente para acompanhar os alunos nas atividades associadas a esta categoria de gastos, que inclui, por exemplo, saídas para estudo de meio e para eventos culturais, no caso das Atividades acadêmico-culturais, e realização de apresentações artístico-culturais, no caso de Eventos e apresentações promovidos pelas escolas.

Especial atenção foi dada à divisão da atuação dos professores entre diferentes formas de atendimento. Em princípio, é possível que todos os alunos estejam considerados nos gastos relativos ao Desenvolvimento do currículo básico. Contudo, gastos adicionais podem ser direcionados aos alunos de educação especial e aos que necessitam de apoio adicional para a melhoria da aprendizagem. Diferenciar estes grupos de despesas é relevante para que seja possível detectar quanto dos gastos são direcionados especificamente a grupos de alunos que demandam mais recursos para que possam ter acesso à aprendizagem adequada. Essa distinção pode contribuir para a identificação da adequação ou não do atendimento a estes alunos e para a minimização de problemas relativos à endogeneidade nas pesquisas que se proponham a analisar quantitativamente a relação entre gastos e desempenho dos alunos.

É possível notar que os gastos com materiais utilizados para o ensino foram separados em uma categoria própria, que não reflete uma atividade ou função das escolas. Isso se deu porque, na maior parte dos casos, esses materiais são utilizados para atividades de ensino de forma geral, independente do grupo de alunos atendidos. Os materiais e equipamentos utilizados em sala de aula pelos professores, por exemplo, estão presentes no desenvolvimento do currículo básico, nas atividades de reforço escolar e no atendimento aos alunos de educação especial, sendo muito difícil, na prática, separar o material utilizado em cada tipo de atividade. 
Já no caso das atividades relativas às Condições para acesso e permanência dos alunos nas escolas, a proposta é a de que os materiais sejam considerados junto à respectiva atividade. Assim, por exemplo, os materiais e equipamentos utilizados para o preparo de refeições para os alunos estariam contidos em Elaboração e fornecimento de alimentação aos alunos. Ainda acerca da categoria Condições para acesso e permanência dos alunos nas escolas, vale dizer que ela reúne atividades que extrapolam aspectos de acesso e permanência dos alunos na escola, podendo ter implicações sobre a aprendizagem.

Como ressalva à proposta apresentada, deve-se dizer que ela constitui uma possibilidade e que, assim como outras classificações, terá pontos a serem criticados e melhoras e adaptações a serem feitas, a depender do contexto. De toda forma, partindo do entendimento de que o agrupamento de gastos, no nível da escola e segundo funções, atividades ou finalidades escolares, pode ser útil para o entendimento de como estes gastos contribuem para um ou diferentes resultados que se possam esperar da experiência escolar dos alunos, pode-se dizer que as categorias apresentadas podem contribuir para o avanço do entendimento sobre a relação entre gastos com educação e desempenho dos alunos.

Conforme exposto, a disponibilidade de dados por escola restringiu-se aos gastos com salários dos profissionais que atuam nas unidades de ensino. Assim, a classificação proposta foi adaptada para os dados disponíveis, conforme será indicado adiante. Antes da apresentação dos dados, de acordo com as categorias em questão, segue-se uma breve contextualização da rede municipal de ensino de São Bernardo do Campo.

\subsection{A rede municipal de ensino de São Bernardo do Campo}

Os dados acerca dos gastos escolares, obtidos para a realização desta pesquisa, são referentes ao ano de 2013. Assim, as informações sobre o contexto da rede de ensino de São Bernardo são referentes ao mesmo ano. A opção por 2013 se deve à disponibilidade de dados da Prova Brasil para este ano, o que viabilizou a exploração da relação entre gastos e desempenho dos alunos.

A rede de ensino do município de São Bernardo do Campo era constituída, em 2013, por 175 escolas e contava com 74.619 alunos matriculados. Destas escolas, aproximadamente 70 
ofereciam ensino fundamental, com um total de matrículas de 40.755 alunos nesta etapa do ensino. Uma característica relevante da rede diz respeito ao fato das escolas oferecerem apenas os anos iniciais do ensino fundamental. Isso foi importante para a delimitação dos gastos por escola, já que não houve necessidade de rateios. Isto é, caso as escolas da rede de São Bernardo do Campo contassem com anos iniciais e finais do ensino fundamental, seria necessário escolher algum critério, como por exemplo, o número de alunos matriculados, para direcionar determinados gastos a cada grupo de alunos. Como os gastos de cada grupo de alunos não são, necessariamente, proporcionais ao número de alunos matriculados, a informação sobre os gastos atribuídos aos anos iniciais e finais do ensino fundamental poderia ser pouco precisa. Ainda neste sentido, também foi característica favorável à realização desta pesquisa o fato de poucas escolas oferecerem simultaneamente educação infantil e ensino fundamental. Desta forma, foi possível excluí-las do total de escolas consideradas, sem grande perda de informação.

Em relação às despesas com educação do município, é possível obter uma visão geral a partir dos dados da despesa liquidada na função educação, conforme divulgados em uma das séries do sistema "Finanças do Brasil - Dados Contábeis dos Municípios" (FINBRA), publicada pela Secretaria do Tesouro Nacional. As informações ali registradas indicam que a prefeitura de São Bernardo do Campo gastou 20\% de seu orçamento de R 2,9 bilhões com educação, sendo aproximadamente $43 \%$ da despesa com educação direcionada ao ensino fundamental. A tabela abaixo indica os valores da despesa liquidada nas subfunções da Função Educação em 2013, a proporção de gastos, o número de matrículas e o gasto por aluno para cada etapa e modalidade de ensino.

TABELA 8 - DESPESA PÚBLICA MUNICIPAL COM EDUCAÇÃO - SÃO BERNARDO DO CAMPO, 2013

\begin{tabular}{l|r|r|r|r}
\hline \multicolumn{1}{c|}{ Etapa/Modalidade } & $\begin{array}{r}\text { Despesa liquidada } \\
\mathbf{2 0 1 3}\end{array}$ & $\begin{array}{r}\text { Desp. Liquidada } \\
\mathbf{( \% )}\end{array}$ & Matrículas & $\begin{array}{c}\text { Gasto por aluno } \\
\text { (subfunções) }\end{array}$ \\
\hline Ensino Fundamental & $249.935 .000,97$ & $42,56 \%$ & 40.755 & $6.132,62$ \\
Ensino Profissional & $3.123 .005,91$ & $0,53 \%$ & - & - \\
Ensino Superior & $12.828 .614,73$ & $2,18 \%$ & - & - \\
Educação Infantil & $211.055 .230,54$ & $35,94 \%$ & 29.494 & $7.155,87$ \\
Educação de Jovens e Adultos & $6.142 .579,90$ & $1,05 \%$ & 4.139 & $1.484,07$ \\
Educação Especial & $13.703 .361,86$ & $2,33 \%$ & 231 & $59.321,91$ \\
Demais Subfunções Educação & $90.427 .458,40$ & $15,40 \%$ & - & - \\
\hline Total & $587.215 .252,31$ & $100,00 \%$ & 74.619 & - \\
\hline Fonte: FINBRA e Censo Escolar. Elaboração própria. & & &
\end{tabular}


Com base número total de matrículas da rede municipal, pode-se estimar que em 2013 a despesa média por aluno foi de $\mathrm{R} \$ 6.443,88^{33}$, sendo de $\mathrm{R} \$ 6.132,62$ a despesa média com o ensino fundamental. De acordo com a Secretaria Municipal de Educação de São Bernardo do Campo, o valor obtido para o gasto por aluno na subfunção "Educação Especial” pode estar relacionado ao já referido problema da consideração da execução orçamentária de um ano como referência para a estimativa de alocação de recursos. Isto é, o valor observado pode estar relacionado a uma formação de estoque de capital (obras de adequação de espaços para o atendimento dos alunos de Educação Especial). Esse estoque, que corresponde a uma despesa executada em 2013, será utilizado por muitos anos, sendo provável que despesas dessa ordem não voltem a se repetir no futuro. Desta forma, a não consideração da informação de custo, que considera a depreciação do estoque de capital, pode estar levando a uma superestimação dos insumos destinados à manutenção das atividades de ensino em Educação Especial no ano de 2013, o que contribuiria para distorções nas estimativas dedicadas a estabelecer uma relação entre recursos e resultados.

No que diz respeito ao nível socioeconômico dos alunos da rede municipal de São Bernardo do Campo, pode-se dizer que varia pouco, sendo alto, quando comparado ao padrão nacional. Considerando a classificação do INEP para o Indicador de Nível Socioecnômico - INSE ${ }^{34}$ (INEP, 2013), 53\% das 73 escolas de ensino fundamental em que foi possível calcular o indicador tinham INSE médio-alto, 44\% contavam com INSE alto, uma teve o INSE classificado como muito alto e uma escola foi classificada como de nível socioeconômico médio.

As notas obtidas na Prova Brasil, por escola, guardam relação significativa com nível socioeconômico médio dos alunos. A Tabela 9 indica os valores médios, máximos, mínimos e o desvio padrão para as notas obtidas pelos alunos do $5^{\circ}$ ano na prova de 2013 , assim como para outros indicadores de contexto da rede. Os gráficos 1 e 2 ilustram a relação entre o desempenho dos alunos e o nível socioeconômico destes.

\footnotetext{
${ }^{33}$ Para chegar ao gasto total por aluno, foram considerados somente os gastos das etapas e modalidades que contam com o registro do número de matrículas: Ensino Fundamental, Educação Infantil, Educação de Jovens e Adultos e Educação Especial.

${ }^{34} \mathrm{O}$ Indicador de Nível Socioeconômico das Escolas - INSE representa uma síntese de medidas relativas à condição social dos alunos, como escolaridade dos pais e disponibilidade de determinados bens em suas casas, por exemplo. O indicador é expresso em uma escala contínua, mas também em sete níveis, que dão origem a sete grupos de nível socioeconômico: Muito baixo, Baixo, Médio Baixo, Médio, Médio alto, Alto e Muito alto.
} 
TABELA 9 - INDICADORES DE CONTEXTO DA REDE MUNICIPAL DE SÃO BERNARDO DO CAMPO

\begin{tabular}{lccccc}
\hline & Min. & Max. & Média & Desvio-padrão & Número de obs. \\
\hline Nota em matemática - Prova Brasil & 187,71 & 258,53 & 227,51 & 14,94 & 69 \\
Nota em português - Prova Brasil & 166,27 & 239,78 & 212,89 & 15,12 & 69 \\
INSE & 49,51 & 62,01 & 55,29 & 2,92 & 73 \\
Perc. de docentes com ensino sup. & 69,20 & 100,00 & 88,36 & 8,44 & 72 \\
Horas de aula por dia & 4,90 & 5,00 & 5,00 & 0,01 & 72 \\
Alunos por turma & 20,70 & 30,60 & 24,90 & 2,04 & 72 \\
\hline
\end{tabular}

Fonte: Prova Brasil 2013 e INEP. Elaboração própria.

A Tabela 9 destaca a situação de três indicadores tipicamente utilizados não só para traçar o perfil de redes de ensino, mas também para investigar a relação entre opções de uso dos recursos e desempenho dos alunos: alunos por turma, horas de aula por dia e proporção de docentes com curso superior. Conforme indicado, praticamente não há variação nas horas diárias de aula da rede (apenas uma escola declarou oferecer 4,9 horas de aula por dia, enquanto o restante informou 5 horas diárias de aula). Desta forma, pode-se presumir que a variação dos gastos por aluno, ao menos no que diz respeito aos gastos com pessoal, podem ser explicados pela variação do salário-hora e pela relação funcionários/aluno, mas não pela variação das horas de aula por dia. Como será visto adiante, ao menos para as escolas consideradas para a realização da análise de regressão, há alta correlação entre alunos por turma e gastos por aluno, o que sugere que boa parte da variação do gasto por aluno em São Bernardo do Campo está associada com o tamanho médio das turmas. 
GRÁFICO 1 - DESEMPENHO EM LÍNGUA PORTUGUESA E NÍVEL SOCIOECONÔMICO ESCOLAS DA REDE MUNICIPAL DE SÃO BERNARDO DO CAMPO

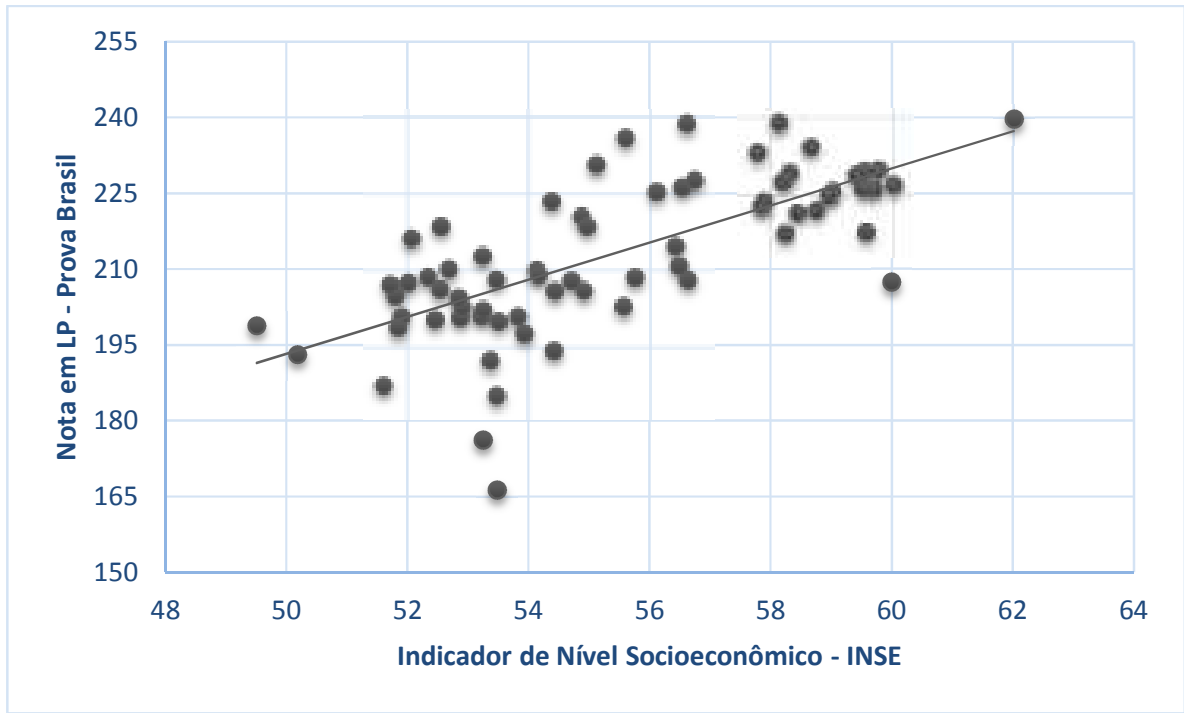

Fonte: Elaborado com base nas informações da Prova Brasil de 2013.

GRÁFICO 2 - DESEMPENHO EM MATEMÁTICA E NÍVEL SOCIOECONÔMICO - ESCOLAS

DA REDE MUNICIPAL DE SÃO BERNARDO DO CAMPO

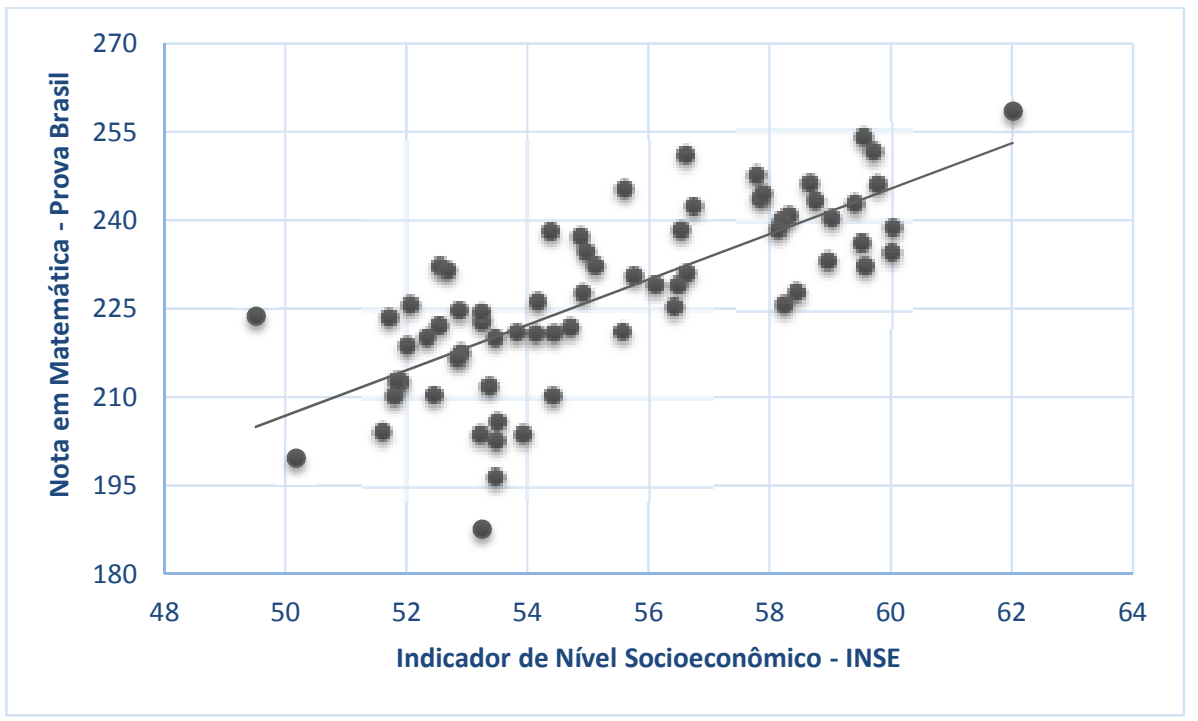

Fonte: Elaborado com base nas informações da Prova Brasil de 2013. 
Os gráficos que ilustram a relação entre as notas na Prova Brasil de 2013 e o Índice de Nível Socioeconômico das escolas indicam uma relação positiva entre as variáveis, relação essa já esperada e amplamente difundida pela literatura que trata do tema, que aponta o nível socioeconômico dos alunos como o principal fator explicativo das notas em exames como a Prova Brasil (ALVES e FRANCO, 2008, p. 491).

Delineado, em linhas gerias, o perfil da rede municipal de educação de São Bernardo do Campo, passamos à descrição e análise das informações de gastos por escola.

\subsection{Os gastos das escolas da rede municipal de ensino de São Bernardo do Campo}

A proposta inicial de classificação de gastos das escolas de São Bernardo do Campo, apresentada no item 3.1 deste trabalho, está em linha com as despesas executadas pela rede, mas nem todas as despesas puderam, no momento de realização deste trabalho, ser mapeadas por escola, conforme já exposto. Assim, parte dos recursos que viabilizam muitas das atividades desenvolvidas nas escolas não pôde ser associada a cada escola.

A informação acerca dos gastos que foi possível viabilizar, com boa precisão, por escola, refere-se à despesa com pessoal. Considerando os estudos sobre custo por aluno produzidos no Brasil, pode-se dizer que o gasto anual com pessoal representa algo entre $65 \%$ e $85 \%$ do custo por aluno. Assim, é possível entender que parte significativa dos recursos alocados às escolas está contemplada nos dados obtidos.

Em relação aos dados não obtidos, os principais gastos não considerados, que seriam de interesse devido ao potencial para afetar as condições de oferta do ensino, são os relativos à alimentação escolar, transporte escolar, material didático, parcela da depreciação de materiais e equipamentos utilizados para o ensino, formação e desenvolvimento profissional e os gastos com manutenção do espaço escolar (pequenos reparos e reformas).

Dentre as escolas de São Bernardo do Campo que oferecem ensino fundamental (cerca de 70), 69 realizaram a Prova Brasil e tiveram as notas médias divulgadas, conforme exposto na seção anterior. Das 69 escolas com notas divulgadas, 6 não tinham informação de gastos disponíveis para 2013 e 8 escolas foram excluídas porque ofereciam simultaneamente 
educação infantil e ensino fundamental. Como os dados disponibilizados não permitiam a separação entre educadores dedicados à educação infantil e ao ensino fundamental, a opção foi excluir estas escolas do total de unidades de ensino a serem consideradas, pois a impossibilidade de direcionar os gastos à respectiva etapa de ensino, com razoável precisão, poderia implicar em erro nas estimativas que relacionam gastos e desempenho dos alunos. A Tabela 10 indica a situação da nota em matemática na Prova Brasil, relativamente à nota média da rede, das escolas excluídas por não terem informações de gasto. Como é possível notar, considerando as exclusões, a análise dos gastos e da relação entre gastos e desempenho será feita para um conjunto de 55 escolas que oferecem exclusivamente os anos iniciais do ensino fundamental.

TABELA 10 - ESCOLAS EXCLUÍDAS DA ANÁLISE E MOTIVO DA EXCLUSÃO

\begin{tabular}{|c|c|c|}
\hline Escola & $\begin{array}{l}\text { Nota PB - } \\
\text { Matemática }\end{array}$ & Motivo da exclusão \\
\hline Escola A & Abaixo da média & Sem dados de gasto \\
\hline Escola B & Abaixo da média & Sem dados de gasto \\
\hline Escola C & Abaixo da média & Sem dados de gasto \\
\hline Escola D & Acima da média & Sem dados de gasto \\
\hline Escola E & Acima da média & Sem dados de gasto \\
\hline Escola $\mathrm{F}$ & Abaixo da média & Sem dados de gasto \\
\hline Escola G & - & Oferece ed. Infantil \\
\hline Escola H & - & Oferece ed. Infantil \\
\hline Escola I & - & Oferece ed. Infantil \\
\hline Escola $\mathrm{J}$ & - & Oferece ed. Infantil \\
\hline Escola K & - & Oferece ed. Infantil \\
\hline Escola L & - & Oferece ed. Infantil \\
\hline Escola M & - & Oferece ed. Infantil \\
\hline Escola N & - & Oferece ed. Infantil \\
\hline
\end{tabular}

Como é possível notar até este ponto, a construção da informação de gastos no nível da escola levou em consideração sempre a relação a ser explorada, entre gastos e desempenho dos alunos. Se o objetivo da pesquisa fosse outro, a consideração de gastos com educação infantil poderia ser útil, a depender da análise a ser feita. A preocupação em construir uma informação que possa ser relacionada com o desempenho dos alunos permeia também a proposta de categorias de gastos, conforme elaborada. Para outros fins, outras propostas de classificação podem ser mais úteis, mas para o objetivo desta pesquisa, a agregação dos gastos 
em categorias que apontam para determinadas finalidades da ação escolar podem ser úteis para o entendimento da relação entre gastos e desempenho, conforme já exposto. A Tabela 11, a seguir, traz a classificação utilizada para a agregação dos gastos com pessoal da rede municipal de São Bernardo do Campo, assim como os valores anualizados agregados das 55 escolas consideradas, para cada categoria de gasto.

TABELA 11 - CATEGORIAS DE GASTO CONSIDERADAS E GASTOS DAS ESCOLAS REDE MUNICIPAL DE SÃO BERNARDO DO CAMPO

\begin{tabular}{crrr}
\hline & Gasto anual & $\begin{array}{c}\text { Gasto por } \\
\text { aluno ano }\end{array}$ & $\begin{array}{c}\text { Percentual em } \\
\text { relação ao gasto total }\end{array}$ \\
\hline Gastos diretamente relacionados ao ensino & $\mathbf{6 1 . 0 4 5 . 7 6 6 , 7 4}$ & $\mathbf{1 . 7 7 5 , 6 2}$ & $\mathbf{8 5 , 7 8 \%}$ \\
\hline Desenvolvimento do currículo básico & $\mathbf{4 6 . 2 6 3 . 4 1 5 , 2 5}$ & $\mathbf{1 . 3 4 5 , 6 5}$ & $\mathbf{6 5 , 0 1 \%}$ \\
Professores & $44.618 .767,05$ & $1.297,81$ & $62,70 \%$ \\
Auxiliares de classe & $1.514 .880,65$ & 44,06 & $2,13 \%$ \\
Estagiários & $129.767,55$ & 3,77 & $0,18 \%$ \\
Desenvolvimento de atividades de ensino - Ed. Especial & $\mathbf{4 . 0 3 8 . 0 8 5 , 5 6}$ & $\mathbf{1 1 7 , 4 5}$ & $\mathbf{5 , 6 7 \%}$ \\
Professores Ed. Especial & $3.250 .829,09$ & 94,56 & $4,57 \%$ \\
Estagiários Ed. Especial & $787.256,47$ & 22,90 & $1,11 \%$ \\
Espaço para pesquisa, leitura e ensino (biblioteca) & $\mathbf{1 . 3 1 1 . 0 8 7 , 4 8}$ & $\mathbf{3 8 , 1 4}$ & $\mathbf{1 , 8 4 \%}$ \\
Orientação e suporte às atividades de ensino e aprendizagem & $\mathbf{9 . 4 3 3 . 1 7 8 , 4 5}$ & $\mathbf{2 7 4 , 3 8}$ & $\mathbf{1 3 , 2 6 \%}$ \\
Coordenação pedagógica & $6.322 .102,33$ & 183,89 & $8,88 \%$ \\
Suporte aos alunos e professores (monitoria) & $3.111 .076,12$ & 90,49 & $4,37 \%$ \\
\hline Gastos indiretamente relacionados ao ensino & $\mathbf{1 0 . 1 1 8 . 0 7 0 , 3 5}$ & $\mathbf{2 9 4 , 3 0}$ & $\mathbf{1 4 , 2 2 \%}$ \\
\hline Gestão escolar & $\mathbf{1 0 . 1 1 8 . 0 7 0 , 3 5}$ & $\mathbf{2 9 4 , 3 0}$ & $\mathbf{1 4 , 2 2 \%}$ \\
Direção da escola & $6.964 .172,06$ & 202,56 & $9,79 \%$ \\
Apoio operacional e administrativo & $3.153 .898,29$ & 91,74 & $4,43 \%$ \\
\hline Total de gastos (direta e indiretamente relacionados ao ensino) & $\mathbf{7 1 . 1 6 3 . 8 3 7 , 0 9}$ & $\mathbf{2 . 0 6 9 , 9 2}$ & $\mathbf{1 0 0 , 0 0 \%}$ \\
\hline Fonte: Elaborado com base em informações fornecidas pela & Secretaria Ede &
\end{tabular}

Fonte: Elaborado com base em informações fornecidas pela Secretaria de Educação de SBC.

O primeiro aspecto a ser reforçado é o fato de que todas as despesas indicadas na tabela são relativas a salários dos profissionais que atuam nas escolas. Se fosse seguida a tendência de classificação frequentemente utilizada em trabalhos que analisam a relação entre gastos e desempenho, a única informação disponível seria a que se encontra na última linha da tabela, referente à despesa com pessoal. Como é possível notar, a desagregação dos gastos, segundo diferentes finalidades ou funções da atividade escolar, implica em um ganho de informação sobre a informação agregada.

Apesar do ganho de informação, os dados produzidos dizem respeito mais à alocação dos recursos em questão do que ao uso. Isto é, a abordagem seguida implica em maior entendimento acerca de como são distribuídos os gastos entre as escolas da rede, mas não dá 
conta da análise das diferentes práticas relativas ao uso dos recursos no dia a dia das escolas. Este seria o passo seguinte de uma pesquisa que procure investir na investigação da alocação e do uso dos recursos escolares. Para tanto, seria necessário intenso trabalho de campo, com observação, realização de entrevistas e preenchimento de formulários. Essa abordagem, que jogaria luz sobre o uso dos recursos, possivelmente passaria pela análise do uso de determinados espaços e equipamentos escolares, assim como do uso do tempo nas escolas. Este tipo de análise, com a comparação de escolas, poderia contribuir para o avanço acerca de como os recursos podem influir nos resultados escolares. De toda forma, pode-se dizer que a análise proposta nesta pesquisa já avança, em alguma medida, na compreensão de como os gastos se relacionam com o desempenho dos alunos.

Pode-se notar que muitas das categorias propostas para a classificação de gastos foram excluídas devido ao fato de não serem mapeáveis por unidade de ensino. Em especial, os gastos classificados como indiretamente relacionados ao ensino coincidem com os gastos relativos à gestão escolar, já que estes últimos são os únicos que constam nos gastos indiretamente relacionados ao ensino. Desta forma, não perdendo de vista a coincidência entre as duas categorias, só serão feitas referências aos gastos com gestão escolar.

Os gastos referentes aos professores especialistas e às horas trabalhadas em atividades de reforço e recuperação estão incluídos no gasto com professores, pois não foi possível desagregar a informação de gasto por escola para estas categorias.

Para a construção da informação por escola foram tomadas uma série de decisões, como as relativas ao tratamento dos gastos com Ensino de Jovens e Adultos - EJA e à agregação de gastos de acordo com a função exercida por cada profissional da escola. As opções feitas são descritas nos parágrafos seguintes.

\subsubsection{A construção da informação de gasto no nível da escola}

As informações recebidas da Secretaria de Educação de São Bernardo do Campo, organizadas em uma planilha, traziam um número de identificação para cada funcionário, o cargo, a função exercida, o nome da escola em que atuam, a carga horária semanal e o salário bruto para um mês do ano de 2013. O dado de salário bruto fornecido não conta com qualquer outra 
parcela de pagamento, como $13^{\circ}$ salário ou outro tipo de parcela variável ou não regular de remuneração, conforme informado pela Secretaria de Educação do município.

A agregação dos salários nas categorias de interesse teve como base a função exercida por cada funcionário, pois é esta a informação que sinaliza o tipo de atividade desempenhada pelos funcionários das escolas. Em alguns casos, por exemplo, a função de diretor é exercida por um funcionário cujo cargo de origem é de professor. A Tabela 12 relaciona as funções existentes nas escolas, indicando a que categoria de gasto cada função foi associada. Desta forma, o salário de cada funcionário foi incluído em determinada categoria de gasto, de acordo com a função exercida.

Vale observar que este trabalho de classificação dos gastos para cada unidade escolar pode ser praticamente inviável, a depender do tamanho da rede de ensino, a não ser que o trabalho seja automatizado ou sistematizado de alguma forma. A chance de erros, com a tabulação manual dos dados, cresce proporcionalmente à tarefa. Em alguns momentos foi preciso refazer parte do trabalho, pois a verificação de consistência dos dados apontava para erros cometidos durante a manipulação dos mesmos.

O estabelecimento da relação entre funções e categorias de gasto teve como base a descrição das funções desempenhadas pelos profissionais que atuam nas escolas, conforme consta na Lei $\mathrm{n}^{\circ}$ 6.316, de 12 de dezembro de 2013 e na Lei $\mathrm{n}^{\circ} 5.820$, de 3 de abril de $2008^{35}$. A agregação feita foi submetida à Secretaria de Educação de São Bernardo do Campo, que apontou um questionamento, referente à inclusão dos professores readaptados na categoria Direção da escola. Considerando que os professores readaptados recebem salários próximos aos dos profissionais que atuam na direção escolar e têm formação semelhante a estes, a opção foi manter os professores readaptados na categoria de direção escolar. De toda forma, uma investigação futura acerca da atuação dos professores readaptados pode indicar a necessidade de revisão das opções de agregação feitas. Uma pesquisa que se detenha em acompanhar as atividades destes professores nas escolas pode revelar que eles atuam mais em trabalhos de apoio administrativo, mais próximos à coordenação pedagógica ou na

\footnotetext{
${ }^{35}$ As referidas leis encontram-se disponíveis em: http://www.legislacao.saobernardo.sp.gov.br/upload/pdf/2013_L/2013_L_06316.pdf e http://www.legislacao.saobernardo.sp.gov.br/upload/pdf/2008 L/2008 L 05820.pdf, respectivamente. Acessado em 19 de junho de 2016.
} 
organização dos espaços de leitura e pesquisa (biblioteca e sala de leitura), por exemplo. A ressalva acerca dos professores readaptados é útil, contudo, para ilustrar uma ressalva geral. Todas as escolhas feitas na agregação de funções, segundo determinada categoria de gasto, precisaria ser melhor investigada em trabalhos futuros. O mapeamento das atividades de cada funcionário, em uma amostra de escolas de rede de São Bernardo do Campo, seria útil para validar, complementar ou refutar algumas das opções feitas, o que tornaria o trabalho de agregação de gastos com salários mais preciso.

\section{TABELA 12 - CATEGORIAS DE GASTO E FUNÇÕES ESCOLARES - REDE MUNICIPAL DE} SÃO BERNARDO DO CAMPO

\begin{tabular}{|c|c|c|}
\hline Categoria & Subcategoria & Função \\
\hline \multirow[t]{3}{*}{$\begin{array}{l}\text { Desenvolvimento do } \\
\text { currículo básico }\end{array}$} & Professores & $\begin{array}{l}\text { Professor de Educação Básica - Fundamental } \\
\text { Professor de Educação Básica I - Fundamental } \\
\text { Professor de Educação Básica - Infantil } \\
\text { Professor de Educação Básica I - Infantil }\end{array}$ \\
\hline & Assistentes de classe & Auxiliar em Educação I \\
\hline & Estagiários & Estagiário em Pedagogia \\
\hline \multirow{2}{*}{$\begin{array}{l}\text { Desenvolvimento de } \\
\text { atividades de ensino } \\
\text { - Educação Especial }\end{array}$} & Professores Ed. Esp. & Professor de Educação Especial \\
\hline & Estagiários Ed. Esp. & $\begin{array}{l}\text { Estagiário de Apoio à Inclusão (Pedagogia) } \\
\text { Estagiário de Apoio à Inclusão }\end{array}$ \\
\hline $\begin{array}{l}\text { Espaço para } \\
\text { pesquisa, leitura e } \\
\text { ensino }\end{array}$ & $\begin{array}{l}\text { Espaço para pesquisa, } \\
\text { leitura e ensino }\end{array}$ & $\begin{array}{l}\text { Agente de Biblioteca e Arquivo } \\
\text { Auxiliar Administrativo de Ensino - Biblioteca Escolar } \\
\text { Interativa (BEI) } \\
\text { Auxiliar de Biblioteca } \\
\text { Oficial Administrativo - Biblioteca Escolar Interativa (BEI) } \\
\text { Oficial de escola - Biblioteca Escolar Interativa (BEI) }\end{array}$ \\
\hline \multirow[t]{2}{*}{$\begin{array}{l}\text { Orientação e suporte } \\
\text { às atividades de } \\
\text { ensino e } \\
\text { aprendizagem }\end{array}$} & $\begin{array}{l}\text { Coordenação } \\
\text { Pedagógica }\end{array}$ & $\begin{array}{l}\text { Coordenador Pedagógico } \\
\text { Professor Coordenador Conveniado } \\
\text { Professor Respondendo pela Coordenação Pedagógica } \\
\text { Professor de Apoio aos Programas Educacionais }\end{array}$ \\
\hline & $\begin{array}{l}\text { Suporte aos alunos e } \\
\text { professores }\end{array}$ & $\begin{array}{l}\text { Inspetor de Alunos } \\
\text { Monitor em educação }\end{array}$ \\
\hline \multirow[t]{2}{*}{ Gestão escolar } & Direção da escola & $\begin{array}{l}\text { Diretor Escolar } \\
\text { Diretor Escolar Conveniado } \\
\text { Professor de Apoio à Direção Escolar } \\
\text { Professor Respondendo por Direção Escolar } \\
\text { Vice-diretor Conveniado } \\
\text { Readaptado }\end{array}$ \\
\hline & $\begin{array}{l}\text { Apoio operacional e } \\
\text { administrativo }\end{array}$ & $\begin{array}{l}\text { Ajudante Geral } \\
\text { Merendeira } \\
\text { Oficial Administrativo } \\
\text { Oficial de Escola } \\
\text { Servente }\end{array}$ \\
\hline
\end{tabular}

Fonte: Elaborado com base em informações fornecidas pela Secretaria de Educação de SBC e na Lei $n^{\circ} 6.316$, de 12 de dezembro de 2013. 
Como é possível notar na Tabela 12, há professores de educação infantil incluídos na categoria que trata dos salários dos professores. Isto não seria esperado, já que foram consideradas apenas escolas que ofereciam exclusivamente ensino fundamental. A Secretaria de Educação informou, contudo, que muitos dos professores que constam na função de educação infantil, atuam no ensino fundamental. Este foi o motivo da desconsideração de escolas que ofereciam educação infantil e, simultaneamente, ensino fundamental: não foi possível distinguir, com base na função, se o professor de educação infantil atuava na educação infantil ou no ensino fundamental, o que impediu que os gastos com salários fossem direcionados para as respectivas etapas de ensino. De toda forma, sendo a escola exclusivamente de ensino fundamental, é certo que o professor atuava nesta etapa de ensino, mesmo que sua função fosse de professor de educação infantil.

Dois grandes grupos de profissionais foram excluídos do total de funcionários considerados: os auxiliares de limpeza e os professores substitutos. Muitas escolas registravam gastos com auxiliares de limpeza, enquanto outras não tinham esta despesa. A diferença de registro, contudo, estava relacionada não com a ausência do serviço, mas sim com a forma de contratação. Parte das escolas tem o serviço de limpeza contratado diretamente, enquanto em outras este serviço é terceirizado. Como não foram considerados os gastos de salários de terceirizados, a opção foi excluir os gastos com salários de auxiliares de limpeza contratados diretamente, para tornar as escolas comparáveis. A indicação do salário segundo cargo e função foi essencial para que fosse viável esse tipo de tratamento.

A exclusão dos gastos com professores substitutos não foi tão simples. A informação disponível na folha de pagamentos traz certa quantidade de professores substitutos para a maior parte das escolas. Ocorre que esta era a situação de pagamentos de professores substitutos, por escola, para o mês considerado. Em outros meses do ano, a distribuição de pagamentos poderia ser diferente, conforme a necessidade de professores substitutos da rede e em cada escola. Além disso, conforme indicado pela Secretaria de Educação do município, é possível que o salário de alguns professores substitutos esteja registrado em uma escola, mas a atuação deles pode ter ocorrido em outras unidades de ensino, além daquelas em que ficou registrado o pagamento. O ponto crucial para a decisão de exclusão dos salários dos professores substitutos foi o entendimento de que os salários dos professores substituídos estavam registrados na folha de pagamentos. Assim, se fossem considerados os salários dos 
professores substitutos, haveria dupla contagem, já que os salários do professor regular e do professor substituto não representavam dois professores em atuação.

Pode-se notar que foi evitado, ao máximo, o uso de critérios indiretos de atribuição dos gastos. Os únicos casos em que foi preciso recorrer a algum tipo de critério de atribuição indireta de gastos estão relacionados ao oferecimento de Educação de Jovens e Adultos - EJA por parte das escolas. Das 55 unidades de ensino consideradas, 30 ofereciam EJA, o que impossibilitou a exclusão das escolas que ofereciam esta modalidade de ensino do total de escolas consideradas.

Tendo em vista que a análise dos dados recairia sobre os anos iniciais do ensino fundamental, a opção foi excluir o número de alunos de EJA do total de alunos matriculados e excluir os gastos com EJA, isto é, excluir os salários relativos às atividades de ensino de jovens e adultos, do total de gastos em cada escola. Felizmente, a classificação de função exercida na escola trazia a identificação dos professores que trabalhavam com ensino de jovens e adultos. Dessa forma, foi possível excluir os salários de professores que trabalhavam com esta modalidade de ensino. Ainda assim, restavam os outros profissionais que atuavam nas escolas. Foi possível notar que, quando uma escola oferecia EJA, havia um maior número de funcionários de coordenação e direção na escola, por exemplo. Como solução, optamos por direcionar os gastos com não docentes de acordo com a proporção de alunos matriculados no ensino fundamental. Assim, em uma escola em que 90\% das matrículas era de alunos do ensino fundamental e $10 \%$ era de alunos de EJA, $90 \%$ dos gastos com salários de coordenadores, diretores etc. foram considerados como o gasto total da escola. Desta forma, no cálculo do gasto por aluno, foram desconsiderados os alunos de EJA no numerador (gasto com salários) e no denominador (alunos matriculados). Pode-se dizer que, ainda que este rateio possa implicar em alguma medida de imprecisão, a distorção da informação de gasto por aluno tende a ser baixa, já que 1) o número de alunos de EJA era baixo na maioria dos casos; e 2) foi possível excluir com precisão a maior parte dos gastos com salários relativos a EJA, considerando que os professores de EJA foram identificados, via classificação indicada na função exercida.

Por fim, vale dizer que alguns dos cargos são residuais nas escolas, havendo por vezes um profissional, em uma escola, que desempenhava determinada função. Estes são os casos dos 
cargos de ajudante geral, merendeira, oficial administrativo, servente e zelador, que tiveram sua função transferida para empresas prestadoras de serviços. Os salários desses funcionários remanescentes foram incorporados à categoria Apoio operacional e administrativo.

Conforme descrito, foram agregados os salários, segundo as categorias indicadas na Tabela 11, que puderam ser atribuídos exclusivamente aos anos iniciais do ensino fundamental e que podiam ser identificados em todas as escolas, tornando-as comparáveis. Para tornar os dados de salários similares aos utilizados em outras pesquisas, os salários referentes a um mês foram multiplicados por 13,33. Este fator, ao representar 12 meses de salário, $13^{\circ}$ salário e férias, faz com que os dados constituam uma estimativa do gasto anual com salários. Desta forma, a Tabela 11 apresenta, em reais de 2013, o gasto anual total, o gasto anual por aluno e a proporção de gasto, para as categorias de agregação dos gastos propostas, das 55 escolas da rede municipal de São Bernardo do Campo consideradas nesta pesquisa.

\subsection{Os gastos por escola e o nível socioeconômico dos alunos}

Os gastos com salários, considerados por escola, apresentaram variação significativa (Tabela 13 e Gráfico 3). Considerando que as escolas pertencem à mesma rede de ensino, a dispersão de gasto por aluno, sobretudo com salários (grupo de despesa em que as escolas, em princípio, não têm poder para influenciar a alocação), contraria o senso comum. Esta desigualdade poderia, em princípio, estar associada com a percepção da Secretaria de Educação sobre diferenças na necessidade de recursos nas escolas (como mais professores disponíveis para escolas que atendem a alunos de nível socioeconômico mais baixo, por exemplo) ou, como sugere Paro (1981), ao poder de pressão de famílias com melhor condição social por mais recursos para as escolas de seus filhos. Outra possibilidade seria a preferência, por parte de profissionais que atuam nas escolas, por determinado perfil de alunos ou por escolas melhor localizadas, considerado o contexto do entorno das escolas. Assim, os mais experientes, que tendem a ter os maiores salários ${ }^{36}$, buscariam trabalhar em determinadas escolas da rede, o que levaria à diferença nos gastos por aluno.

\footnotetext{
${ }^{36}$ A Lei $\mathrm{n}^{\circ} 5.820$, de 3 de abril de 2008 indica que os profissionais que atuam na rede municipal de São Bernardo do Campo devem cumprir um tempo mínimo em cada nível da respectiva carreira, para que seja possível uma promoção. Assim, a evolução salarial está associada ao tempo de atuação na rede.
} 
Um exemplo de variação do gasto por aluno que pode estar relacionado a diferenças de necessidade de recursos pode ser obtido no gasto com educação especial por aluno. Seria de se esperar que escolas que não tiveram matrículas de alunos de educação especial não tenham gasto com salários de professores de educação especial. Assim, a desigualdade de necessidade de recursos poderia explicar, ao menos em parte, a desigualdade do gasto total por aluno neste caso. A relação entre necessidade de recursos para educação especial e o número de alunos atendidos nesta modalidade será explorada adiante, em seção própria.

TABELA 13 - GASTO POR ESCOLA SEGUNDO AS CATEGORIAS DE GASTO CONSIDERADAS - REDE MUNICIPAL DE SÃO BERNARDO DO CAMPO

\begin{tabular}{lcccc}
\hline & Min. & Max. & Média & $\begin{array}{c}\text { Desvio- } \\
\text { padrão }\end{array}$ \\
\hline Gasto por Aluno - Total & $1.516,85$ & $3.277,67$ & $2.171,59$ & 352,76 \\
Gasto diretamente relacionado ao ensino & $1.316,26$ & $2.773,16$ & $1.844,57$ & 277,40 \\
Desenvolvimento do currículo básico & $1.032,27$ & $1.953,59$ & $1.371,82$ & 178,44 \\
Desenvolvimento de atividades de ensino - Ed. Especial & 0,00 & 594,52 & 127,58 & 93,30 \\
Espaço para pesquisa, leitura e ensino (biblioteca/sala de leitura) & 0,00 & 172,17 & 44,52 & 29,85 \\
Orientação e suporte às atividades de ensino e aprendizagem & 174,59 & 518,72 & 300,65 & 83,32 \\
Gestão escolar & 187,24 & 816,25 & 327,02 & 115,33 \\
\hline Alunos por turma & 20,70 & 30,60 & 25,30 & 2,02 \\
Percentual de docentes com ensino superior & 0,719 & 1,000 & 0,893 & 0,076 \\
INSE & 51,61 & 62,01 & 55,73 & 2,73 \\
\hline Fonte: Elaborac
\end{tabular}

Fonte: Elaborado com base em informações fornecidas pela Secretaria de Educação de SBC e INEP.

\section{GRÁFICO 3 - DISTRIBUIÇÃO DAS ESCOLAS SEGUNDO O GASTO TOTAL POR ALUNO - REDE MUNICIPAL DE SÃO BERNARDO DO CAMPO}

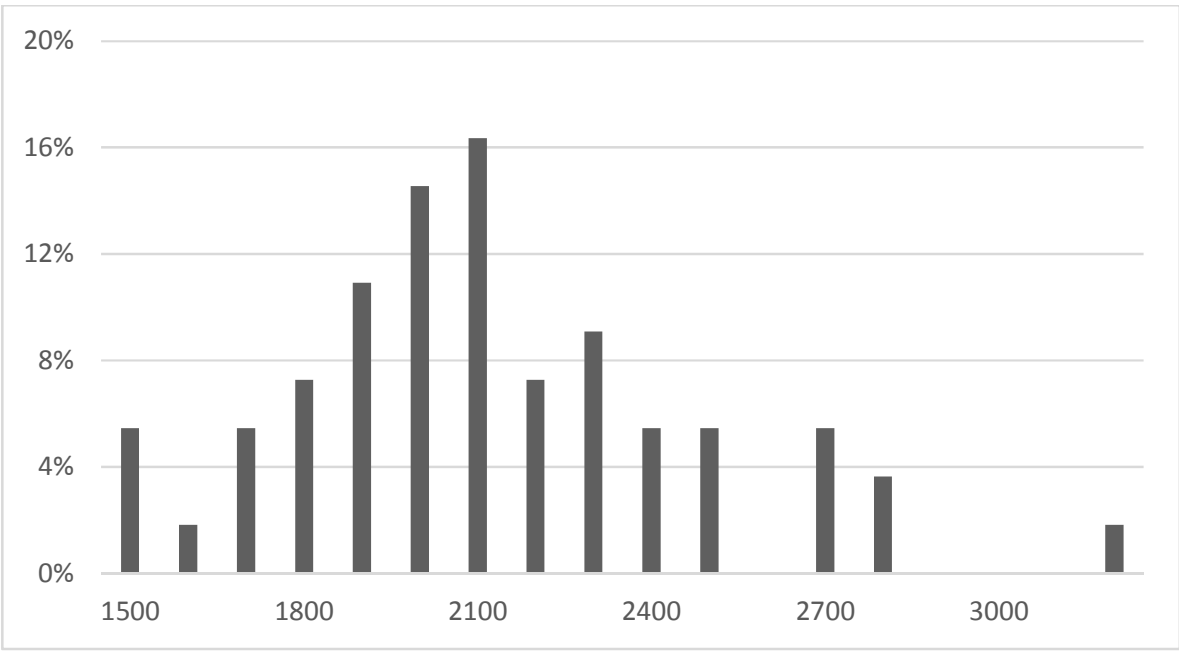

Fonte: Elaborado com base em informações fornecidas pela Secretaria de Educação de SBC. 
Como já sinalizado na seção que trata do contexto da rede de São Bernardo, o Índice de Nível Socioeconômico das escolas é predominantemente médio alto e alto. Como é possível observar na Tabela 13, a diferença entre os valores máximo e mínimo do INSE é pouco maior que 10, em um indicador que tem mínimo de 14,4 e máximo de 65,5, considerando as redes municipais de todo país, o que reforça a concentração do índice em uma faixa estreita de valores. O Gráfico 4 ilustra a distribuição do INSE das escolas.

\section{GRÁFICO 4 - DISTRIBUIÇÃO DAS ESCOLAS SEGUNDO O INDICADOR DE NÍVEL SOCIOECONÔMICO - REDE MUNICIPAL DE SÃO BERNARDO DO CAMPO}

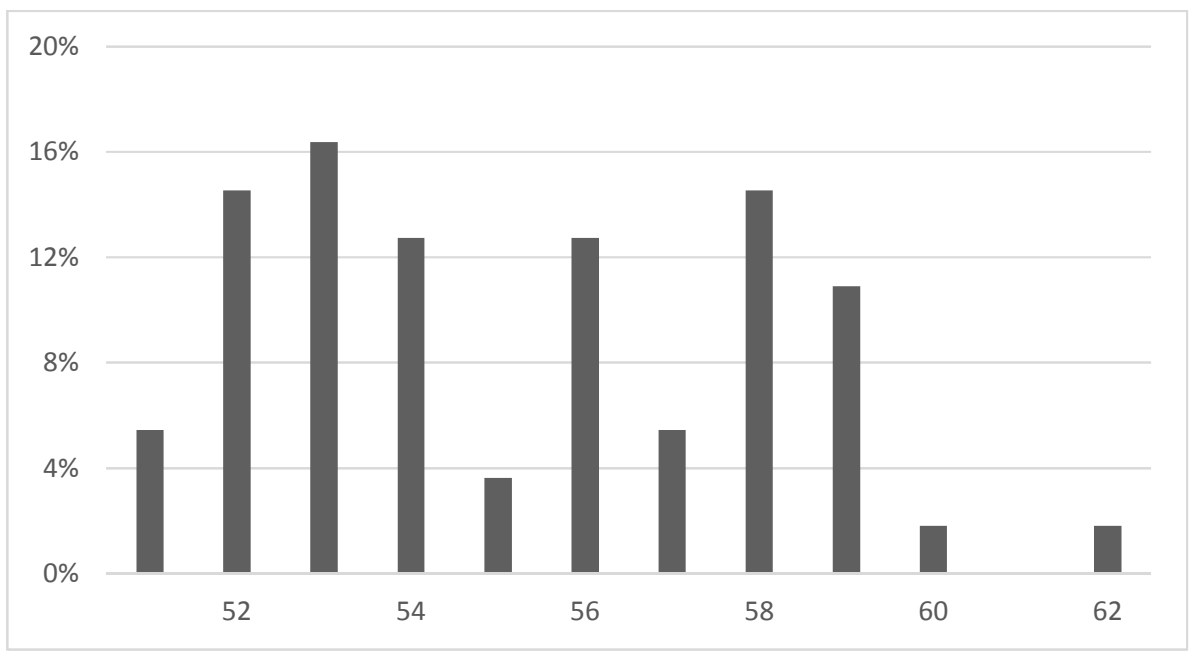

Fonte: Elaborado com base nas informações da Prova Brasil de 2013.

Quando considerados os gastos segundo as categorias de nível socioeconômico, é possível notar que as escolas classificadas como de INSE alto tendem a ter maiores gastos por aluno com direção da escola, enquanto as de INSE médio alto apresentam maior gasto por aluno com professores, na média. A tabela abaixo traz os valores médios de gasto por aluno, segundo a categoria de gasto e de acordo com nível socioeconômico das escolas. 
TABELA 14 - GASTO POR ALUNO, SEGUNDO NÍVEL SOCIOECONÔMICO

\begin{tabular}{crr} 
& INSE alto & INSE médio alto \\
\hline Gasto aluno total & 2190,01 & 2139,07 \\
\hline Gasto dir. relacionado ao ensino & 1844,80 & 1833,32 \\
Desenvolv. currículo básico & 1354,21 & 1386,03 \\
Professores & 1298,10 & 1335,12 \\
Assist. classe ${ }^{37}$ & 56,11 & 50,91 \\
Espaço pesquisa, leitura e ensino & 43,82 & 43,94 \\
Orient. e suporte ensino & 306,37 & 294,37 \\
Coordenação pedagógica & 209,48 & 196,64 \\
Suporte aos alunos e prof. & 96,89 & 97,73 \\
\hline Gestão escolar & 345,21 & 305,75 \\
Direção da escola & 252,50 & 205,19 \\
Apoio operacional e adm. & 92,71 & 100,56 \\
\hline Fonte: Elaborado com base em informações fornecidas pela Secretaria de Educação \\
de SBC.
\end{tabular}

Ainda que não seja o foco deste trabalho, considerando que um dos principais fatores associados à variação do gasto por aluno, conforme relatado pela literatura, é o perfil socioeconômico dos alunos, exploramos esta relação, de forma simples, a partir da sequência de gráficos a seguir, que ilustra a correlação entre diferentes medidas de disponibilidade de recursos e o nível socioeconômico dos alunos.

${ }^{37}$ Considerando a função exercida e o pouco número de ocorrências, os gastos com estagiários (que correspondem a menos de $0,3 \%$ dos gastos da categoria "Desenvolvimento do currículo básico") foram incorporados à categoria "Assistente de classe". 
GRÁFICOS 5 A 12 - INSE E MEDIDAS DE DISPONIBILIDADE DE RECURSOS ESCOLARES
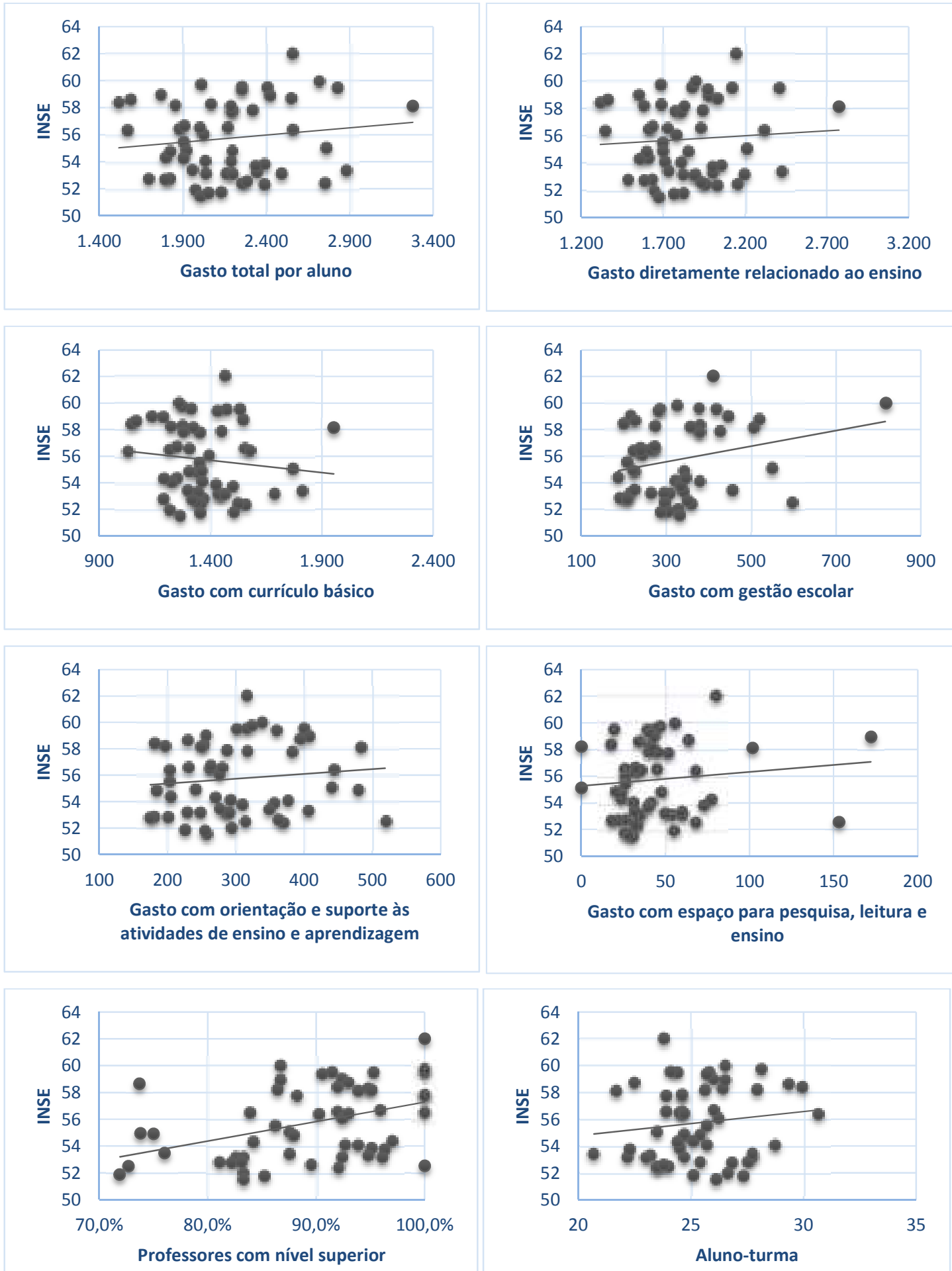

Fonte: Elaborado com base em informações fornecidas pela Secretaria de Educação de SBC e INEP. 
O primeiro ponto de destaque nos gráficos diz respeito à fraca associação entre o nível socioeconômico dos alunos e a maior parte das medidas de recursos. A inclinação das retas é baixa, qualquer que seja o sentido da relação, com excessão do gráfico que trata do percentual de professores com nível superior ${ }^{38}$. Assim, pode-se dizer que, ao que parece, há uma maior proporção de professores com nível superior nas escolas que atendem alunos de maior nível socioeconômico. Diante disso, caso a formação do professor tenha alguma influência sobre sua capacidade de escolher a unidade de ensino em que atuará, uma linha de investigação que poderia ser seguida diz respeito ao estudo das preferências dos professores por lecionar em escolas com alunos de determinado nível socioeconômico ou em escolas localizadas em regiões da cidade que atendem alunos de dado nível socioeconômico.

Outro ponto a ser destacado, é o fato de que as relações indicadas não seguem um sentido único. Se os dados não fossem divididos em diferentes categorias de gastos, sendo a relação entre o INSE e o gasto total por aluno a única a ser observada, a conclusão possível indicaria que há uma fraca relação positiva entre nível socioeconômico dos alunos e o gasto por aluno. Ainda que esta informação seja verdadeira, ela é incompleta. O desdobramento dos gastos indica, por exemplo, que o gasto por aluno no conjunto de despesas que engloba os salários dos professores (gasto com Desenvolvimento do currículo básico) tem relação negativa, ainda que fraca, com o nível socioeconômico dos alunos. Isto é, quanto menor o INSE, maior tende a ser o gasto com salários de professores, por aluno, o que pode ser reflexo de turmas menores nas escolas de menor nível socioeconômico, considerado o último gráfico da sequência (INSE X Aluno-turma).

Esta breve seção não teve como objetivo explorar a fundo as causas da variação dos gastos por escola, já que isso foge ao escopo deste trabalho, mas sim indicar que esta desigualdade existe e que pode estar associada a diferentes fenômenos ou motivações. Além disso, procurou-se destacar que a desagregação do gasto em diferentes categorias, assim como a exploração da informação no nível da escola, podem ser úteis para análises que procurem explorar as desigualdades escolares existentes e a relação entre estas desigualdades e outras variáveis de interesse, como a condição social dos alunos ou os resultados destes em testes.

\footnotetext{
${ }^{38}$ A inclinação da reta do gráfico que relaciona o INSE dos alunos aos gastos com Gestão Escolar também se destaca das demais, mas sofre a influência de um outlier, o que motivou a referência apenas ao gráfico que trata da relação entre Professores com nivel superior e INSE.
} 


\subsection{Os gastos com educação especial}

Das 55 escolas consideradas, apenas uma não tem gastos com educação especial. As despesas com educação especial foram divididas em gastos com professores de educação especial e com estagiários, que representam $80,5 \%$ e $19,5 \%$ do gasto total com educação especial, respectivamente. A análise do gasto por escola indica que a contratação de estagiários tem sido uma das estratégias da rede municipal de São Bernardo para o atendimento aos alunos em questão. Das 54 escolas que tiveram gastos com educação especial, 49 registraram pagamento de estagiários, que chegam ao número de 6 em uma das escolas ${ }^{39}$.

Conforme visto até aqui, a abertura da informação de gasto por aluno, segundo as categorias de gasto propostas, permite a obtenção do gasto com educação especial por aluno. Este dado, contudo (gasto com educação especial dividido pelo total de alunos matriculados na escola), não constitui informação de grande utilidade prática. Mais precisa é a informação do gasto com educação especial segundo o número de matrículas nesta modalidade de ensino, já que torna possível o estabelecimento de uma relação entre necessidade e oferta de recursos, tornando as escolas comparáveis.

Os dados da Prova Brasil, relativos ao questionário do diretor, trazem intervalos de valores que indicam o número de alunos de educação especial atendidos na escola. Esta informação não permite que seja identificado o número exato de alunos de educação especial em cada escola, o que impede o cálculo do gasto com educação especial por aluno de educação especial atendido. Desta forma, a opção foi associar o gasto total (e não por aluno) com educação especial aos intervalos que indicam o número de alunos atendidos (Tabela 15).

\footnotetext{
${ }^{39}$ A Secretaria Municipal de Educação de São Bernardo do Campo indicou que a contratação de estagiários para apoiar o atendimento aos alunos de Educação Especial não era mais uma prática no ano de 2016, quando esta dissertação foi finalizada.
} 
TABELA 15 - GASTO ANUAL TOTAL COM EDUCAÇÃO ESPECIAL (SALÁRIOS) E

NÚMERO DE ALUNOS DE EDUCAÇÃO ESPECIAL, POR ESCOLA

\begin{tabular}{|c|c|c|c|}
\hline $\begin{array}{l}\mathbf{N}^{0} \text { alunos Ed. } \\
\text { Especial }\end{array}$ & $\begin{array}{c}\text { Gasto anual } \\
\text { médio - Ed. } \\
\text { Especial } \\
\end{array}$ & Desv. Pad. & Freq. \\
\hline $1-5$ & $51.110,18$ & $39.905,17$ & 9 \\
\hline $6-10$ & $65.605,60$ & $32.601,71$ & 20 \\
\hline $11-20$ & $94.885,64$ & $66.137,04$ & 17 \\
\hline 20 ou mais & $69.680,52$ & $18.051,96$ & 7 \\
\hline
\end{tabular}

Pode-se notar que a maior parte das escolas atende entre 6 e 20 alunos de educação especial e que há correspondência, em alguma medida, entre o número de alunos atendidos e o gasto anual com o salário de professores e estagiários que atuam com estes alunos. Em relação às 55 escolas consideradas, duas não informaram os intervalos que indicam o número de alunos atendidos.

Tendo em vista o interesse em entender, ao menos em parte, a variação do gasto por aluno entre as escolas, consideramos pertinente testar se há algum indício de relação entre a necessidade (alunos de educação especial atendidos) e a oferta de recursos (gasto anual com educação especial), por escola. Caso tal correspondência exista, será possível inferir que ao menos parte da variação do gasto total por aluno está relacionada à diferença de necessidade de recursos.

A verificação da existência de relação entre necessidade e oferta de recursos para educação especial deveria incluir, contudo, inúmeros controles que não serão considerados, o que torna a estimativa proposta sujeita a ressalvas. Por exemplo, seria de se esperar que o nível médio de salários de atividades alternativas de trabalho influenciasse os salários dos professores, o que influenciaria, por sua vez, o gasto anual com educação especial. Outro ponto a ser considerado consiste no baixo número de observações, que pode implicar em menor precisão das estimativas. Desta forma, fica indicada a necessidade de estudos futuros que tenham como base um número maior de observações e uma gama variada de variáveis explicativas.

$\mathrm{Na}$ tentativa de incluir mais um fator que possa explicar os gastos com educação especial e supondo que o nível socioeconômico dos alunos possa ter influência sobre o gasto anual com educação especial, incluímos o INSE das escolas na estimativa feita. Assim, em resumo, 
testamos se o número de alunos de educação especial atendidos e o nível socioeconômico deles explicam, em alguma medida, a variação do gasto anual com esta modalidade de ensino. Desta forma, foi estimada a seguinte equação:

$$
\log \left(\text { gasto }_{\mathrm{i}}=\alpha+\beta\left(n^{\mathrm{o}} \text { alunos }\right)_{\mathrm{i}}+\gamma(I N S E)_{\mathrm{i}}+\varepsilon_{\mathrm{i}}\right.
$$

em que $\log$ (gasto) é o logaritmo do gasto anual com educação especial, $n^{o}$ alunos representa uma variável que assume valor igual a 1 quando o número de alunos de educação especial é maior ou igual a 11 e 0 caso contrário, INSE é o Indicador de nível socioeconômico da escola e $\varepsilon_{i}$ é o termo de erro. O método utilizado para a estimativa dos coeficientes foi o de mínimos quadrados ordinários.

TABELA 16 - RESULTADOS REGRESSÃO - VARIÁVEL DEPENDE: LOG GASTO TOTAL COM EDUCAÇÃO ESPECIAL

\begin{tabular}{lcc}
\hline & $(1)$ & $(2)$ \\
\hline & & \\
$\mathrm{N}^{\mathrm{o}}$ alunos & $0.364^{*}$ & $0.391^{*}$ \\
& $(0.199)$ & $(0.206)$ \\
& & 0.022 \\
$\mathrm{INSE}$ & & $(0.037)$ \\
& & \\
& & $9.592^{* * *}$ \\
Constante & $10.851^{* * *}$ & $(2.113)$ \\
\hline Observações & $(0.133)$ & 54 \\
$\mathrm{R}^{2}$ & 54 & 0.067 \\
$\mathrm{R}^{2}$ Ajustado & 0.060 & 0.030 \\
Prob>F & 0.042 & 0.173 \\
\hline Fonte: Elaboração própria. Erro padrão em parênteses. Significância \\
dos coeficientes: *** $1 \% ; * * 5 \% ;{ }^{*} 10 \%$.
\end{tabular}

Os resultados obtidos, conforme indicados na Tabela 16, permitem concluir que há uma relação positiva e estatisticamente significante entre a quantidade de alunos de educação especial atendidos e o gasto anual com esta modalidade de ensino. Isto é, o fato do número de alunos atendidos ser superior a 10 está associado a um gasto anual com educação especial $36 \%$ maior que o das escolas que atendem 10 alunos ou menos ${ }^{40}$.

\footnotetext{
${ }^{40}$ Tendo em vista os resultados para os parâmetros $\mathrm{R}^{2}$ ajustado e Teste $\mathrm{F}$, a especificação da coluna 1 foi considerada como a que melhor representa a relação entre número de alunos atendidos e o gasto-ano com educação especial.
} 
Ainda que seja um resultado esperado, este poderia não ser o resultado observado na prática. A influência de outros critérios, que não a quantidade de alunos atendidos, poderia levar a uma distribuição aparentemente aleatória dos recursos. Ou a influência do nível socioeconômico dos alunos poderia implicar em uma distribuição dos recursos em que este critério prevalecesse sobre o de número de alunos atendidos, o que não é o caso. Como indicado, o coeficiente relativo ao INSE não é estatisticamente significante.

Diante do exposto, pode-se sugerir que a variação do gasto total por aluno esteja associada, ao menos em parte, a uma variação da demanda por recursos destinados à educação especial, sendo estes representados pelos salários pagos a professores e estagiários. Nota-se que, neste caso, diferentes quantidades de recursos disponibilizados às escolas não implicariam, necessariamente, em diferenças nos resultados. Isto é, escolas que atendem a um número maior de alunos de educação especial podem incorrer em um gasto total por aluno maior, mas este gasto a mais é útil para viabilizar um tipo de atendimento, não correspondendo a recurso a mais que deveria se transformar em resultado a mais.

\subsection{Gastos por aluno e desempenho}

A existência de uma relação entre gastos por aluno e desempenho pode ser entendida como desejável, mas a verificação desta relação através da análise de dados merece algumas considerações. O caminho percorrido entre, por exemplo, o salário depositado na conta de um professor e o resultado em um teste de larga escala em uma determinada matéria, é longo. Nem toda variação de gasto é dirigida para o ensino de um conteúdo específico, nem todo ensino de um conteúdo específico é assimilado de forma imediata, nem tudo o que foi apreendido pode ser captado em um teste anual, sobre o qual o aluno, muitas vezes, pouco sabe a respeito.

Neste sentido, ainda que pareça uma lembrança desnecessária, vale dizer que as escolas não se assemelham nem um pouco a fábricas, em que um conjunto bem delimitado de insumos dá origem a um produto final, físico, palpável, diretamente relacionado à quantidade de insumos utilizada e cuja produção deve ser maximizada. A utilização de ferramentas vinculadas a análises do tipo insumo-produto, que foram concebidas para a análise de contextos de produção (empresas, indústrias ou, genericamente, “firmas”), é útil para a análise de outros 
fenômenos, em outros contextos, mas não se pode cair no equívoco de, junto com a ferramenta, trazer a fábrica para a escola. Dito de outra forma, as finalidades da educação escolar são múltiplas, alguns dos resultados esperados não são mensuráveis e, talvez em muitos casos, os efeitos do que se passa nas escolas se revelam fora dos tempos dos testes.

De toda forma, o desenvolvimento de determinadas habilidades e competências é um dos efeitos esperados da experiência escolar, constituindo uma das vias de realização do direito à educação. Portanto, entender como os gastos efetuados podem contribuir para viabilização da aprendizagem esperada não deixa de ser pertinente. Passamos, assim, a indicar os passos seguidos para a análise da relação entre gastos escolares e o desempenho dos alunos, em linha com o objetivo desta pesquisa.

Conforme já indicado, a informação acerca dos gastos escolares foi construída tendo em vista a exploração da relação entre gastos e desempenho dos alunos. Em termos de desempenho, a opção feita foi por utilizar os resultados obtidos em matemática, na Prova Brasil de 2013, pelos alunos do $5^{\circ}$ ano do ensino fundamental da rede municipal de São Bernardo do Campo. Os dados de desempenho foram considerados no nível da escola, conforme o desempenho médio divulgado pelo $\mathrm{INEP}^{41}$.

A opção por matemática se deve ao fato desta matéria ser tipicamente escolar, sendo possível entender que a aprendizagem dos alunos guarda significativa relação com o que se passa na escola. O desempenho em língua portuguesa, por sua vez, apesar das atividades desenvolvidas nas escolas, sofre forte influência da vivência dos alunos em outros contextos, sobretudo o familiar. Assim, pode-se dizer que é mais difícil "isolar" o efeito que variáveis escolares possam ter sobre o desempenho em língua portuguesa (CHUDGAR E LUSCHEI, 2009). Portanto, como o interesse é captar o efeito dos gastos das escolas sobre o desempenho, optamos pelo desempenho em matemática.

É válido lembrar que as escolas foram selecionadas segundo a disponibilidade de informações de gasto e não segundo os dados de desempenho, restando 55 escolas com informações sobre gasto e desempenho, dentre as 69 escolas com nota em matemática divulgada. De toda forma, como critério de validade da informação acerca da nota média dos alunos em cada escola, foi estabelecido que somente poderiam ser levadas em conta na análise as escolas em que mais de

\footnotetext{
${ }^{41}$ Os dados foram obtidos no arquivo relativo à escola, que compõe os microdados da Prova Brasil de 2013. Disponível em http://portal.inep.gov.br/basica-levantamentos-acessar.
} 
75\% dos alunos tivessem participado da Prova Brasil de 2013. As 55 escolas consideradas atenderam a este critério.

O Gráfico 13 ilustra a distribuição das notas em matemática das 55 escolas, que representam aproximadamente $80 \%$ das escolas participantes da Prova Brasil de 2013 da rede municipal de São Bernardo do Campo. A menor nota observada, a maior e a nota média das escolas foram $187,71,258,53$ e 228,70 , respectivamente.

\section{GRÁFICO 13 - DISTRIBUIÇÃO DAS ESCOLAS SEGUNDO A NOTA EM MATEMÁTICA NA PROVA BRASIL DE 2013 - REDE MUNICIPAL DE SÃO BERNARDO DO CAMPO}

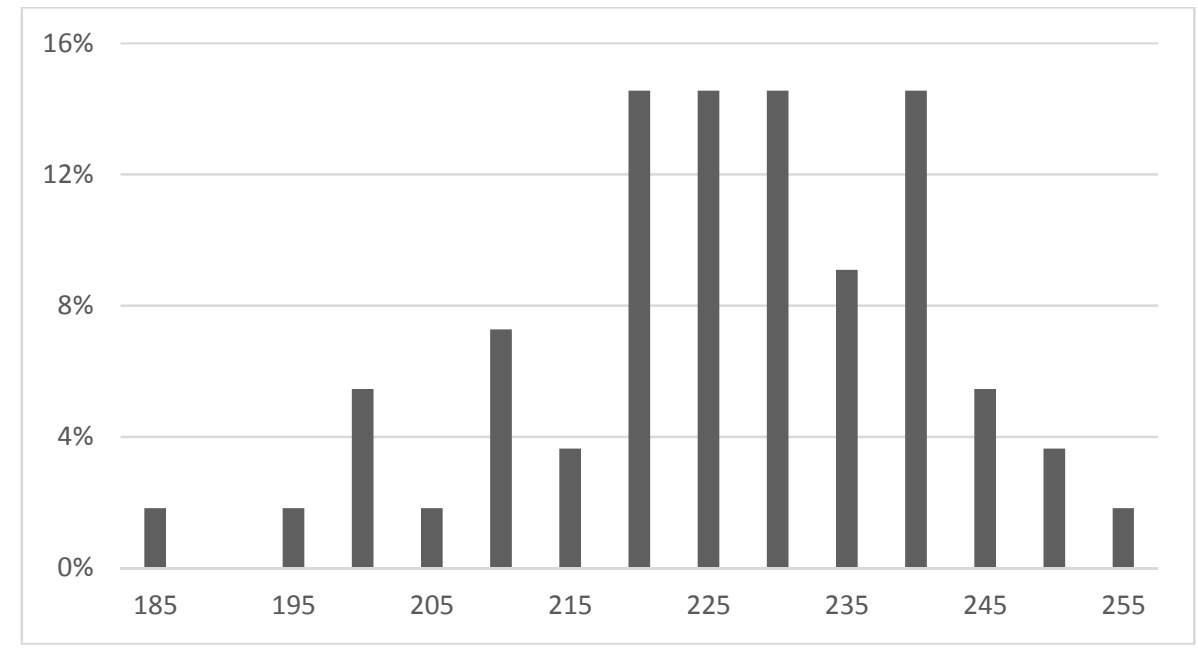

Fonte: Elaborado com base nos dados da Prova Brasil de 2013.

Em relação à etapa de ensino a ser observada, o objetivo era considerar apenas os resultados referentes aos anos iniciais do ensino fundamental. Conforme apontado por Chudgar e Luschei (2009, p. 636), a progressão dos alunos no sistema de ensino pode estar relacionada à seleção dos alunos que, tendo maior suporte familiar para permanecer na escola, conseguiram viabilizar a continuidade de seus estudos. Assim, quanto mais avançada a etapa do ensino, maior seria o viés de seleção e mais difícil tende a ser a separação entre efeitos da família e os da escola sobre o aprendizado. De toda forma, como a rede de ensino considerada na pesquisa oferece somente os anos iniciais do ensino fundamental, os dados obtidos se adequaram perfeitamente à proposta de pesquisa.

Em uma primeira tentativa de observar algum tipo de relação entre o desempenho em matemática e os gastos, segundo as principais categorias de agregação do gasto, foi estimada 
a correlação ${ }^{42}$ entre o gasto por aluno e o desempenho em matemática (Tabela 17). Além dos gastos, foram adicionadas mais algumas variáveis de interesse, como o INSE das escolas, alunos por turma e percentual de docentes com ensino superior.

A observação da tabela permite notar que a maior parte das correlações verificadas é fraca ou moderada. Especialmente em relação às categorias de gasto por aluno e desempenho, nota-se que o coeficiente de correlação de maior valor absoluto é baixo $(0,2073)$. A única correlação positiva digna de nota entre uma medida relativa a recursos e o desempenho das escolas na Prova Brasil refere-se à relação entre percentual de docentes com ensino superior e nota em matemática. De toda forma, coeficientes de correlação podem apontar para possíveis relações entre variáveis, mas não expressam causalidade e não consideram relações simultâneas entre diversas variáveis.

As correlações altas entre categorias de gastos de maior agregação (gasto total por aluno, por exemplo) e suas desagregações são esperadas, já que representam relações entre o todo e suas partes. Valem ser mencionadas, contudo, as correlações positivas entre Gasto diretamente relacionado ao ensino e Gestão escolar, Desenvolvimento do currículo básico e Orientação e suporte às atividades de ensino e aprendizagem, e entre está última categoria e Gestão escolar. Ao que parece, os gastos com orientação e suporte aos alunos, representados em boa medida pelos gastos com coordenação, guardam relação positiva tanto com o gasto por aluno com a remuneração de professores (principal categoria dentro de Desenvolvimento currículo básico) quanto com a remuneração da equipe de Gestão escolar.

Ainda considerando os coeficientes de correlação, destacamos a relação entre alunos por turma com o INSE e com os gastos relativos ao Desenvolvimento do currículo básico. Notase que, ainda que a correlação seja fraca, há alguma associação entre turmas maiores e maiores INSE, conforme já ilustrado graficamente. Isso pode indicar certa tendência de alocação de mais professores para escolas que atendem a alunos de nível socioeconômico mais baixo. Em relação à alta correlação entre alunos por turma e Desenvolvimento do currículo básico, pode-se dizer que esta relação sugere que a variabilidade de gasto por aluno com pagamento de salários de professores está associada sobretudo ao tamanho das turmas, o que estaria em linha com os resultados obtidos por Verhine (2006), que identificou a relação

\footnotetext{
${ }^{42}$ Para esta finalidade, foram estimados coeficientes de correlação de Pearson.
} 
matrícula/docente como relevante para a determinação do custo por aluno do conjunto de escolas consideradas no referido trabalho. 
TABELA 17 - CORRELAÇÃO ENTRE GASTOS, DESEMPENHO MÉDIO DAS ESCOLAS EM MATEMÁTICA E OUTRAS VARIÁVEIS DE INTERESSE

\begin{tabular}{|c|c|c|c|c|c|c|c|c|c|c|c|}
\hline & $\begin{array}{c}\text { Nota Mat. } \\
\text { PB }\end{array}$ & INSE & $\begin{array}{c}\text { Gasto por } \\
\text { Aluno - } \\
\text { Total }\end{array}$ & $\begin{array}{l}\text { Gasto } \\
\text { diretamente } \\
\text { relacionado } \\
\text { ao ensino }\end{array}$ & $\begin{array}{l}\text { Desenv. } \\
\text { currículo } \\
\text { básico }\end{array}$ & $\begin{array}{l}\text { Desenv. de } \\
\text { ativ. de } \\
\text { ensino - } \\
\text { Ed. Esp. }\end{array}$ & $\begin{array}{c}\text { Esp. para } \\
\text { pesquisa, } \\
\text { leitura e } \\
\text { ensino }\end{array}$ & $\begin{array}{l}\text { Orientação e } \\
\text { suporte às } \\
\text { ativ. de } \\
\text { ensino }\end{array}$ & $\begin{array}{l}\text { Gestão } \\
\text { escolar }\end{array}$ & $\begin{array}{l}\text { Alunos } \\
\text { por turma }\end{array}$ & $\begin{array}{l}\% \text { docentes } \\
\text { com ensino } \\
\text { sup. }\end{array}$ \\
\hline Nota Mat. PB & 1 & 0,7441 & $-0,0100$ & $-0,0799$ & $-0,2073$ & 0,0054 & 0,1086 & 0,1331 & 0,1615 & 0,0523 & 0,2669 \\
\hline INSE & & 1 & 0,1384 & 0,0730 & $-0,1203$ & 0,3112 & 0,1133 & 0,1116 & 0,2478 & 0,1328 & 0,4067 \\
\hline Gasto por Aluno - Total & & & 1 & 0,9611 & 0,7783 & 0,5421 & 0,4989 & 0,7472 & 0,7471 & $-0,6454$ & 0,3113 \\
\hline Gasto diretamente relacionado ao ensino & & & & 1 & 0,8634 & 0,5757 & 0,4312 & 0,6811 & 0,5343 & $-0,6733$ & 0,2851 \\
\hline Desenvolvimento do currículo básico & & & & & 1 & 0,2579 & 0,0928 & 0,4109 & 0,3038 & $-0,6932$ & 0,1099 \\
\hline Desenvolvimento de atividades de ensino - Ed. Especial & & & & & & 1 & 0,2510 & 0,1547 & 0,2732 & $-0,1794$ & 0,3307 \\
\hline Espaço para pesquisa, leitura e ensino & & & & & & & 1 & 0,5975 & 0,4888 & $-0,2642$ & 0,2420 \\
\hline Orientação e suporte às atividades de ensino e aprendizagem & & & & & & & & 1 & 0,6473 & $-0,4616$ & 0,2570 \\
\hline Gestão escolar & & & & & & & & & 1 & $-0,3545$ & 0,2663 \\
\hline Alunos por turma & & & & & & & & & & 1 & $-0,2108$ \\
\hline Perc. de docentes com ensino superior & & & & & & & & & & & 1 \\
\hline
\end{tabular}

Fonte: Elaborado com base em informações fornecidas pela Secretaria de Educação de SBC, Prova Brasil 2013 e INEP. 
Em uma segunda tentativa de explorar relações possíveis entre gastos e desempenho, foi seguida a sugestão dada por Picus (1995), que indica como relevante o exercício de comparação da alocação e uso dos recursos entre escolas em que os alunos apresentam desempenhos distintos. Para tanto, as escolas foram ordenadas segundo o INSE e divididas em quartis (maiores INSE no primeiro quartil e menores no quarto quartil). Tendo em vista a pouca variabilidade do INSE das escolas de São Bernardo do Campo, consideramos que as escolas pertencentes a um mesmo quartil são muito semelhantes entre si, no que diz respeito ao nível socioeconômico dos alunos. Assim, supomos que as diferenças de desempenho entre as escolas estariam associadas principalmente a fatores escolares. Após a separação em quartis de INSE, foram selecionadas as escolas com os dois maiores (primeira e segunda escola de cada bloco de quatro escolas da tabela) e os dois menores desempenhos (terceira e quarta escola de cada bloco de quatro escolas da tabela) em cada quartil. Estas escolas, então, foram comparadas quanto ao gasto por aluno e quanto à distribuição percentual dos gastos, segundo as categorias propostas (Tabelas 18 e 19).

É possível notar que nos dois quartis de INSE mais alto e no mais baixo o gasto por aluno tende a ser maior nas escolas de melhor desempenho, em todas as categorias de gasto. Esta tendência se inverte, porém, no terceiro bloco de escolas. Mais relevante que o gasto por aluno, entretanto, é a distribuição percentual do gasto entre as diferentes categorias. A identificação de algum padrão de distribuição dos gastos nas escolas de maior desempenho poderia indicar uma forma de alocação dos recursos que esteja associada a melhores resultados.

Os dados dispostos na Tabela 19 não permitem, contudo, que seja identificado um padrão claro dos gastos, que diferencie as escolas com maior das de menor desempenho. Talvez a única observação que possa ser feita é a de que as escolas com maior desempenho parecem ter uma proporção menor de gasto com o Desenvolvimento do currículo básico. Isso pode indicar a relevância dos gastos com as demais categorias ou a falta de recursos das escolas que tem baixo desempenho, o que levaria a uma maior concentração de gastos com as atividades relativas ao Desenvolvimento do currículo básico. 
TABELA 18 - GASTOS POR ALUNO DAS ESCOLAS COM MAIORES E MENORES NOTAS NA PROVA BRASIL, SEGUNDO O QUARTIL DE NÍVEL SOCIOECONÔMICO

\begin{tabular}{|c|c|c|c|c|c|c|c|}
\hline Escolas & $\begin{array}{l}\text { Gasto por } \\
\text { Aluno - } \\
\text { Total }\end{array}$ & $\begin{array}{l}\text { Gasto diret. } \\
\text { relacionado ao } \\
\text { ensino }\end{array}$ & $\begin{array}{c}\text { Desenv. currículo } \\
\text { básico }\end{array}$ & $\begin{array}{c}\text { Desenv. de } \\
\text { atividades de } \\
\text { ensino - Ed. Esp. }\end{array}$ & $\begin{array}{c}\text { Esp. pesq. } \\
\text { leitura e ensino }\end{array}$ & $\begin{array}{l}\text { Orient. e suporte } \\
\text { às ativ. de ensino } \\
\text { e aprend. }\end{array}$ & Gestão escolar \\
\hline Escola A1 & $2.552,37$ & $2.142,16$ & $1.463,50$ & 283,80 & 79,13 & 315,74 & 410,21 \\
\hline Escola A2 & $2.403,01$ & $2.117,68$ & $1.530,44$ & 252,34 & 19,55 & 315,34 & 285,33 \\
\hline Escola B1 & $1.516,85$ & $1.316,26$ & $1.046,19$ & 70,85 & 17,79 & 181,43 & 200,58 \\
\hline Escola B2 & $1.853,89$ & $1.579,69$ & $1.222,31$ & 160,54 & 0,00 & 196,84 & 274,20 \\
\hline Escola C1 & $2.000,72$ & $1.726,25$ & $1.305,05$ & 96,36 & 44,61 & 280,23 & 274,47 \\
\hline Escola C2 & $2.187,28$ & $1.808,24$ & $1.352,52$ & 22,65 & 51,22 & 381,84 & 379,05 \\
\hline Escola D1 & $1.569,24$ & $1.345,66$ & $1.032,27$ & 78,11 & 32,03 & 203,24 & 223,58 \\
\hline Escola D2 & $1.904,43$ & $1.695,47$ & $1.350,28$ & 115,46 & 26,31 & 203,42 & 208,96 \\
\hline Escola E1 & $1.902,88$ & $1.557,42$ & $1.192,16$ & 18,69 & 76,36 & 270,21 & 345,46 \\
\hline Escola E2 & $1.824,30$ & $1.597,85$ & $1.341,10$ & 48,50 & 23,73 & 184,52 & 226,46 \\
\hline Escola F1 & $2.385,02$ & $2.052,29$ & $1.424,42$ & 200,26 & 72,08 & 355,53 & 332,72 \\
\hline Escola F2 & $2.487,00$ & $2.191,98$ & $1.685,28$ & 217,95 & 59,38 & 229,37 & 295,02 \\
\hline Escola G1 & $2.747,08$ & $2.152,10$ & $1.355,27$ & 124,99 & 153,11 & 518,72 & 594,98 \\
\hline Escola G2 & $2.280,23$ & $1.930,18$ & $1.337,57$ & 163,65 & 67,20 & 361,75 & 350,05 \\
\hline Escola H1 & $2.004,19$ & $1.672,39$ & $1.263,72$ & 120,76 & 30,18 & 257,73 & 331,80 \\
\hline Escola H2 & $2.196,86$ & $1.889,31$ & $1.462,28$ & 102,01 & 34,75 & 290,27 & 307,55 \\
\hline
\end{tabular}

Fonte: Elaborado com base em informações fornecidas pela Secretaria de Educação de SBC. 
TABELA 19 - PROPORÇÃO DO GASTO POR ALUNO DAS ESCOLAS COM MAIORES E MENORES NOTAS NA PROVA BRASIL, SEGUNDO O QUARTIL DE NÍVEL SOCIOECONÔMICO

\begin{tabular}{|c|c|c|c|c|c|c|}
\hline \multirow[b]{2}{*}{ Escola } & $\begin{array}{l}\text { Perc. Gasto } \\
\text { diret. ensino }\end{array}$ & $\begin{array}{l}\text { Perc. Gasto - } \\
\text { currículo básico }\end{array}$ & $\begin{array}{l}\text { Perc. Gasto - educ. } \\
\text { especial }\end{array}$ & $\begin{array}{c}\text { Perc. Gasto - espaço } \\
\text { leitura }\end{array}$ & $\begin{array}{l}\text { Perc. Gasto - orient. e } \\
\text { suporte ensino }\end{array}$ & $\begin{array}{l}\text { Perc. Gasto - gestão } \\
\text { escolar }\end{array}$ \\
\hline & & & & & & \\
\hline Escola A1 & 0,84 & 0,57 & 0,11 & 0,03 & 0,12 & 0,16 \\
\hline Escola A2 & 0,88 & 0,64 & 0,11 & 0,01 & 0,13 & 0,12 \\
\hline Escola B1 & 0,87 & 0,69 & 0,05 & 0,01 & 0,12 & 0,13 \\
\hline Escola B2 & 0,85 & 0,66 & 0,09 & 0,00 & 0,11 & 0,15 \\
\hline Escola C1 & 0,86 & 0,65 & 0,05 & 0,02 & 0,14 & 0,14 \\
\hline Escola C2 & 0,83 & 0,62 & 0,01 & 0,02 & 0,17 & 0,17 \\
\hline Escola D1 & 0,86 & 0,66 & 0,05 & 0,02 & 0,13 & 0,14 \\
\hline Escola D2 & 0,89 & 0,71 & 0,06 & 0,01 & 0,11 & 0,11 \\
\hline Escola E1 & 0,82 & 0,63 & 0,01 & 0,04 & 0,14 & 0,18 \\
\hline Escola E2 & 0,88 & 0,74 & 0,03 & 0,01 & 0,10 & 0,12 \\
\hline Escola F1 & 0,86 & 0,60 & 0,08 & 0,03 & 0,15 & 0,14 \\
\hline Escola F2 & 0,88 & 0,68 & 0,09 & 0,02 & 0,09 & 0,12 \\
\hline Escola G1 & 0,78 & 0,49 & 0,05 & 0,06 & 0,19 & 0,22 \\
\hline Escola G2 & 0,85 & 0,59 & 0,07 & 0,03 & 0,16 & 0,15 \\
\hline Escola H1 & 0,83 & 0,63 & 0,06 & 0,02 & 0,13 & 0,17 \\
\hline Escola H2 & 0,86 & 0,67 & 0,05 & 0,02 & 0,13 & 0,14 \\
\hline
\end{tabular}

Fonte: Elaborado com base em informações fornecidas pela Secretaria de Educação de SBC. 
Por fim, foi explorada a relação entre gastos por aluno e desempenho via análise de regressão. Os coeficientes, estimados por Mínimos Quadrados Ordinários, indicam a relação entre cada variável explicativa e a variável dependente, que no caso deste trabalho é a nota em matemática na Prova Brasil de 2013, obtida pelos estudantes da rede municipal de São Bernardo do Campo. Em linhas gerais, o método utilizado estima a função que melhor se ajusta aos dados, através da minimização da soma do quadrado dos resíduos, sendo estes representados pela diferença entre os valores observados e os valores preditos da variável dependente (WOOLDRIDGE, 2006).

Ainda em relação ao método utilizado, fica a ressalva quanto à limitação imposta pelo número de observações. As estimativas feitas contaram com 55 observações, com dados de gastos e desempenho no nível das escolas. Este número de observações não é o ideal para a análise empregada e implicará, dentre outras coisas, em limitação quanto ao número possível de variáveis explicativas (HAIR et al, 2009, p. 168). Desta forma, o foco recaiu sobre as variáveis explicativas de interesse, isto é, as variáveis de gasto. Em relação a outras variáveis de controle, considerando o já conhecido poder explicativo do nível socioeconômico dos alunos sobre o desempenho, foi utilizado o INSE, conforme divulgado pelo INEP. Além disso, extrapolando o número recomendado de variáveis, foram considerados controles adicionais em um dos modelos.

A ausência de diversas variáveis de controle comumente consideradas, contudo, tem sua gravidade minimizada pelo fato de muitas características das escolas apresentarem pouca ou nenhuma variação. A rede municipal considerada mostrou-se bastante homogênea, tanto em termos da infraestrutura das escolas quanto em relação a práticas escolares diversas. Por exemplo, 49 das 55 escolas declararam possuir biblioteca em boas condições e todas as escolas disseram oferecer ações de reforço escolar (monitoria, aula de reforço, recuperação etc.). De toda forma, para a seleção das variáveis que permaneceram nos modelos finais, foi considerado o interesse teórico por determinados fatores e levados em conta os critérios tradicionalmente utilizados para a seleção de modelos, como o $\mathrm{R}^{2}$ e o teste $\mathrm{F}$, que indicam a capacidade explicativa da regressão e a significância conjunta dos coeficientes estimados, respectivamente. Além disso, para a seleção dos controles que extrapolam as variáveis 
relativas a gasto e nível socioeconômico, foram considerados os resultados apontados pela técnica Stepwise ${ }^{43}$ de regressão.

Os modelos estimados tiveram como base a seguinte equação:

$$
\text { Nota em matemática }_{\mathrm{i}}=\alpha+\beta \text { Gasto }_{\mathrm{i}}+\gamma(I N S E)_{\mathrm{i}}+\text { demais controles }+\varepsilon_{\mathrm{i}}
$$

em que a variável dependente é a nota em matemática na Prova Brasil, Gasto representa o conjunto de variáveis relativas ao gasto por aluno, segundo as categorias propostas neste trabalho, INSE é o Indicador de nível socioeconômico médio de cada escola, e Demais controles se refere a variáveis relativas à experiência do diretor e ao tempo gasto com a manutenção da disciplina em sala de aula. Esta última variável, obtida a partir dos valores médios das turmas de cada escola, foi construída de forma a assumir valor 1 quando menos de $10 \%$ do tempo é dedicado à disciplina da turma e 0 , caso contrário.

Os resultados obtidos para as estimativas dos coeficientes podem ser observados nas Tabelas 20 e 21. Antes de comentá-los, contudo, é pertinente lembrar que não deve ser atribuído um sentido de causalidade à relação observada entre as variáveis independentes e a variável dependente. Isto é, as variáveis explicativas podem ser entendidas como fatores associados ao desempenho, no contexto da rede municipal de São Bernardo do Campo, mas não como causa do desempenho. Assim, os coeficientes estimados representam uma relação observada no ano de 2013, mas não indicam uma medida de causa e efeito entre gastos e desempenho dos alunos. Para avançar no sentido do estabelecimento de relações causais, seria necessária outra abordagem metodológica e uma base de dados que contasse com informações para mais de um período, o que facilitaria o controle de parte dos efeitos não observáveis que influenciam o desempenho dos alunos.

A primeira tabela, que traz 8 diferentes especificações, é pouco útil para a análise da relação entre gastos e desempenho, mas pertinente para a avaliação do comportamento dos resultados quando os dados são abertos, segundo as diferentes categorias de gastos. Caso a única

\footnotetext{
${ }^{43}$ Regressão Stepwise é uma técnica utilizada para a inclusão ou exclusão de variáveis, considerando o acréscimo de informação de cada variável incluída em uma regressão. Cada variável incluída pode ser aceita ou rejeitada no modelo, que se reconfigura considerando a informação que cada variável incluída traz. Mais detalhes podem ser obtidos em: http://www.jmp.com/support/help/Stepwise Regression Models.shtml, acessado em 22/05/2016.
} 
informação disponível fosse a de gasto total por aluno (que neste caso é restrita à despesa com pessoal), os resultados obtidos seriam os dispostos nas colunas 1 e 2 . Nota-se que o coeficiente estimado para o gasto total por aluno está longe de ser significante, tanto na regressão que inclui só a variável de gasto (coluna 1) quanto na que considera o nível socioeconômico médio de cada escola. $\mathrm{O}$ teste $\mathrm{F}$ e o $\mathrm{R}^{2}$ confirmam a total falta de relação entre gasto e desempenho.

A abertura dos dados em Gastos diretamente relacionados ao ensino e Gestão escolar implicam em uma mudança significativa no que seria a conclusão inicial. O coeficiente de gestão escolar passa a ser positivo e significante na equação sem o controle do nível socioeconômico dos alunos. O poder explicativo dessa mesma especificação ganha relevância e o teste $\mathrm{F}$, apesar de não confirmar a significância conjunta das variáveis, apresenta melhoria considerável em relação ao mesmo parâmetro da coluna 1 .

Nas colunas 5 e 6 foi possível testar a relação entre as categorias principais de gasto e o desempenho, sendo excluída a categoria relativa aos gastos com educação especial, que fazia parte do gasto diretamente relacionado ao ensino ${ }^{44}$. Nas colunas 7 e 8 foram testadas apenas as categorias que se mostraram mais relevantes estatisticamente. De toda forma, após a inclusão da variável INSE, nenhum dos coeficientes relativos a gastos se mostrou significante (coluna 8). A menor relevância da variável relativa aos gastos com salários dos funcionários responsáveis pelas bibliotecas das escolas pode estar relacionada com uma menor influência destes nas atividades de ensino.

Ainda que a Tabela 20 apresente modelos que não confirmam uma relação entre gastos e desempenho, ela é relevante no sentido de ilustrar o ganho de informação que a abertura dos gastos, segundo as categorias propostas, pode trazer. A comparação entre as duas primeiras colunas e as duas últimas parece sugerir que o estabelecimento de categorias de gasto que apontem menos para classificações econômicas da despesa e mais para as atividades ou funções escolares viabilizadas pelos recursos alocados mostra-se como um caminho promissor para que se avance no sentido de entender não somente se os recursos importam, mas como eles importam.

\footnotetext{
${ }^{44}$ A exclusão desta categoria foi justificada anteriormente, na seção 3.5, dedicada especialmente aos gastos com educação especial.
} 
A partir das categorias de maior agregação, dispostas na Tabela 20, foram selecionadas variáveis de menor nível de agregação. Optamos por excluir as variáveis Suporte aos alunos e professores e Apoio operacional e administrativo, pressupondo que tendem a ter menos relevância que as demais para a explicação do desempenho dos alunos. A falta de significância estatística dessas variáveis e a melhoria da especificação dos modelos após sua exclusão validaram, de certa forma, a opção feita. Os testes de Breusch-Pagan e Shapiro-Wilk confirmaram as hipóteses de homocedasticidade e de normalidade dos resíduos, respectivamente, para as três especificações da Tabela 21. Os resultados obtidos para o Fator de Inflação da Variância - VIF indicaram não haver problemas de multicolinearidade.

Os coeficientes das variáveis consideradas estão dispostos na Tabela 21. Na primeira coluna, em que o controle do nível socioeconômico dos alunos não é considerado, as variáveis relativas ao Salário dos professores e dos Assistentes de classe são significantes e apresentam sinal negativo, o que é o contrário do que seria esperado. Já os gastos por aluno com Coordenação pedagógica estão positivamente associados ao desempenho dos alunos, sendo o coeficiente estimado significante. Os gastos com Direção escolar, por sua vez, não são estatisticamente significantes. Vale notar que o $\mathrm{R}^{2}$ e a estatística $\mathrm{F}$ apresentam melhora significativa em relação aos resultados obtidos na Tabela 20, sendo os coeficientes estimados conjuntamente significantes.

Considerando a relevância do nível socioeconômico dos alunos para a explicação do desempenho, os resultados dispostos nas colunas 2 e 3, que incluem a variável INSE, representam os de melhor especificação, isto é, os modelos que melhor representam a relação entre gastos e desempenho dos alunos para a rede municipal de São Bernardo do Campo. Pode-se notar que, para o conjunto de dados testado, há uma associação negativa entre os gastos com Assistentes de classe e o desempenho dos alunos, que varia entre 0,057 e 0,062. Esse resultado indica que uma variação de, por exemplo, R\$ 10,00 no gasto por aluno com assistentes de classe - uma variação grande, considerando que a média do gasto por aluno nesta categoria é de R\$ 52,90 -, estaria associada a uma variação negativa de aproximadamente 0,6 na nota média em matemática.

Os motivos dessa associação negativa podem ser diversos. Uma avaliação dos critérios de alocação dos assistentes de classe entre as escolas e uma melhor compreensão da atuação 
desses profissionais ajudaria a avançar no entendimento da relação observada. Vale frisar, contudo, que o resultado obtido não permite qualquer tipo de conclusão sobre a pertinência ou não desses gastos ou acerca da atuação de assistentes de classe nas escolas de São Bernardo do Campo. Como nos lembra Bourdieu, não se deve cair aqui no erro de "confundir as coisas da lógica com a lógica das coisas” (1998, p.144). Em primeiro lugar, os gastos com assistentes de classe podem representar um bem em si, já que viabilizam determinadas atividades desenvolvidas pelas escolas e os alunos devem ter garantido seu direito à educação. Em segundo lugar, é possível que se o resultado considerado fosse outro - que não a nota na Prova Brasil em matemática -, outra relação fosse observada. Em terceiro lugar, lembramos novamente que estes resultados representam uma busca por melhor compreensão acerca de fatores associados ao desempenho, mas não permitem qualquer conclusão sobre relações de causalidade entre as variáveis. Desta forma, é possível que a relação negativa observada ocorra porque mais gastos com Assistentes de classe estejam sendo direcionados para escolas com desempenho médio mais baixo justamente por causa desse desempenho, o que nos levaria ao já indicado problema de endogeneidade dos gastos. Assim, vale reforçar que um melhor entendimento da alocação destes profissionais entre as escolas da rede contribuiria para a compreensão do resultado observado.

Talvez o principal achado desta pesquisa, no sentido de entender como a alocação dos recursos pode se relacionar com o desempenho dos alunos, seja o relativo aos gastos com Coordenação pedagógica. Essa categoria de gasto é a única que atinge nível de significância inferior a $5 \%$, mantendo-se significante e positivamente relacionada às notas em matemática nas três especificações testadas. Os coeficientes obtidos indicam que uma variação de, por exemplo, R\$10,00 - que é baixa, considerando um gasto médio de R \$203,44 nesta categoria - no gasto por aluno com Coordenação pedagógica está associada a um acréscimo de 0,5 a 0,61 na nota em matemática das escolas da rede considerada. O valor obtido para o coeficiente associado ao gasto por aluno com Coordenação não é alto, mas o fato de ter se mostrado estatisticamente relevante e positivamente associado ao desempenho indica que o tema merece maior atenção e estudos futuros. Em geral, os questionários contextuais aplicados junto aos testes em larga escala tendem a privilegiar aspectos relativos aos professores e diretores, recolhendo informações sobre práticas escolares, salários etc. destes dois grupos de profissionais. Ao que parece, a consideração dos educadores que atuam na 
coordenação pedagógica das escolas poderia contribuir para o avanço do entendimento acerca dos fatores associados ao desempenho dos alunos, dentre outros aspectos. 
TABELA 20 - RESULTADOS REGRESSÃO A - VARIÁVEL DEPENDENTE: NOTA EM MATEMÁTICA NA PROVA BRASIL DE 2013

\begin{tabular}{|c|c|c|c|c|c|c|c|c|}
\hline & (1) & (2) & (3) & (4) & (5) & (6) & (7) & $(8)$ \\
\hline Gasto tot. aluno & $\begin{array}{l}-0.000 \\
(0.006)\end{array}$ & $\begin{array}{l}-0.005 \\
(0.004)\end{array}$ & & & & & & \\
\hline INSE & & $\begin{array}{c}4.121^{* * *} \\
(0.499)\end{array}$ & & $\begin{array}{c}4.009^{* * *} \\
(0.512)\end{array}$ & & $\begin{array}{c}3.923^{* * *} \\
(0.528)\end{array}$ & & $\begin{array}{c}3.927^{* * *} \\
(0.523)\end{array}$ \\
\hline Gasto dir. ens. & & & $\begin{array}{c}-0.012 \\
(0.008)\end{array}$ & $\begin{array}{l}-0.009 \\
(0.006)\end{array}$ & & & & \\
\hline Gest. escolar & & & $\begin{array}{c}0.037^{*} \\
(0.020)\end{array}$ & $\begin{array}{c}0.009 \\
(0.014)\end{array}$ & $\begin{array}{c}0.021 \\
(0.023)\end{array}$ & $\begin{array}{l}-0.009 \\
(0.016)\end{array}$ & $\begin{array}{c}0.019 \\
(0.022)\end{array}$ & $\begin{array}{l}-0.010 \\
(0.016)\end{array}$ \\
\hline Curríc. básico & & & & & $\begin{array}{c}-0.028^{* *} \\
(0.012)\end{array}$ & $\begin{array}{l}-0.014 \\
(0.009)\end{array}$ & $\begin{array}{c}-0.027^{* *} \\
(0.012)\end{array}$ & $\begin{array}{l}-0.014 \\
(0.008)\end{array}$ \\
\hline Pesq. e leitura & & & & & $\begin{array}{l}-0.030 \\
(0.086)\end{array}$ & $\begin{array}{l}-0.019 \\
(0.059)\end{array}$ & & \\
\hline Orient. e sup. & & & & & $\begin{array}{c}0.036 \\
(0.037)\end{array}$ & $\begin{array}{c}0.034 \\
(0.025)\end{array}$ & $\begin{array}{c}0.030 \\
(0.032)\end{array}$ & $\begin{array}{c}0.030 \\
(0.022)\end{array}$ \\
\hline Constante & $\begin{array}{c}229.618^{* * *} \\
(12.693)\end{array}$ & $\begin{array}{c}9.526 \\
(27.995)\end{array}$ & $\begin{array}{c}239.618^{* * *} \\
(13.469)\end{array}$ & $\begin{array}{c}19.220 \\
(29.621)\end{array}$ & $\begin{array}{c}250.479^{* * *} \\
(15.361)\end{array}$ & $\begin{array}{c}23.446 \\
(32.333)\end{array}$ & $\begin{array}{c}250.094^{* * *} \\
(15.188)\end{array}$ & $\begin{array}{c}22.966 \\
(32.003)\end{array}$ \\
\hline Número de obs. & 55 & 55 & 55 & 55 & 55 & 55 & 55 & 55 \\
\hline R2 & 0.000 & 0.567 & 0.065 & 0.575 & 0.116 & 0.584 & 0.113 & 0.584 \\
\hline R2 Ajustado & -0.019 & 0.550 & 0.029 & 0.550 & 0.045 & 0.542 & 0.061 & 0.550 \\
\hline Prob $>F$ & 0.942 & 0.000 & 0.175 & 0.000 & 0.180 & 0.000 & 0.102 & 0.000 \\
\hline
\end{tabular}

Fonte: elaboração própria. Erro padrão em parênteses. Significância dos coeficientes: *** 1\%; ** 5\%; *10\%. 
TABELA 21 - RESULTADOS REGRESSÃO B - VARIÁVEL DEPENDENTE: NOTA EM MATEMÁTICA NA PROVA BRASIL DE 2013

\begin{tabular}{|c|c|c|c|}
\hline & (1) & $(2)$ & (3) \\
\hline Professores & $\begin{array}{l}-0.025^{* *} \\
(0.011)\end{array}$ & $\begin{array}{c}-0.013 \\
(0.008)\end{array}$ & $\begin{array}{c}-0.012 \\
(0.008)\end{array}$ \\
\hline Assist. Classe & $\begin{array}{l}-0.094^{*} \\
(0.047)\end{array}$ & $\begin{array}{l}-0.057^{*} \\
(0.033)\end{array}$ & $\begin{array}{l}-0.062^{*} \\
(0.034)\end{array}$ \\
\hline Coordenação & $\begin{array}{c}0.071^{*} \\
(0.036)\end{array}$ & $\begin{array}{c}0.050^{*} \\
(0.025)\end{array}$ & $\begin{array}{l}0.061^{* *} \\
(0.025)\end{array}$ \\
\hline Direção & $\begin{array}{c}0.018 \\
(0.019)\end{array}$ & $\begin{array}{l}-0.010 \\
(0.014)\end{array}$ & $\begin{array}{l}-0.020 \\
(0.014)\end{array}$ \\
\hline INSE & & $\begin{array}{l}3.839^{* * *} \\
(0.526)\end{array}$ & $\begin{array}{c}3.361^{* * *} \\
(0.527)\end{array}$ \\
\hline Expdir 3 a 10 & & & $\begin{array}{l}6.573^{*} \\
(3.349)\end{array}$ \\
\hline Experdir $11+$ & & & $\begin{array}{l}9.083^{* *} \\
(3.762)\end{array}$ \\
\hline Tempo disciplina & & & $\begin{array}{c}6.197 \\
(4.929)\end{array}$ \\
\hline Constante & $\begin{array}{c}247.739^{* * *} \\
(14.897)\end{array}$ & $\begin{array}{c}27.229 \\
(31.947)\end{array}$ & $\begin{array}{c}45.373 \\
(31.462)\end{array}$ \\
\hline Núm. & 55 & 55 & 54 \\
\hline $\mathrm{R} 2$ & 0.170 & 0.603 & 0.671 \\
\hline R2 Ajus & 0.104 & 0.562 & 0.613 \\
\hline Prob $>F$ & 0.049 & 0.000 & 0.000 \\
\hline
\end{tabular}

Fonte: elaboração própria. Erro padrão em parênteses. Significância dos coeficientes: $* * * 1 \% ; * * 5 \% ; * 10 \%$.

Assim como no caso do gasto com Assistentes de classe, seriam necessárias pesquisas de viés qualitativo para que fosse possível entender melhor as razões por traz da relação observada entre gastos com Coordenação e o desempenho dos alunos em matemática. De toda forma, tendo em vista os resultados obtidos, pode-se dizer que uma estratégia de melhoria do desempenho dos alunos da rede municipal de São Bernardo do Campo, que levasse em conta a alocação dos recursos disponíveis, deveria considerar o efeito que os gastos com coordenação podem ter sobre o desempenho.

Em relação ao gasto por aluno com a direção das escolas, não foram obtidos resultados estatisticamente significantes. Novamente, isso não indica a falta de relevância destes gastos para as escolas ou para os alunos. Apenas mostra que, para a rede em questão, estes gastos não estão associados, positiva ou negativamente, ao desempenho em matemática na Prova 
Brasil de 2013. O mesmo pode ser dito sobre o gasto com salários dos professores. Especificamente neste caso, seria desejável uma maior desagregação dos dados, que tornasse possível a observação do gasto por aluno segundo a disciplina oferecida e de acordo com os alunos atendidos, no caso das aulas de reforço e recuperação. Essa desagregação seria útil para a delimitação de parte dos gastos com salários de professores que varia em função do desempenho dos alunos. De toda forma, tendo em vista as categorias de gasto consideradas, é válida a realização de trabalhos futuros que contem com dados para mais de um ano e que utilizem abordagem metodológica que possa, com base em dados no nível da escola, identificar não somente a associação entre gastos e desempenho, mas verificar se uma variação do gasto, ocasionada por algum fator independe tanto do gasto quanto do desempenho, causa uma melhoria do desempenho dos alunos.

Em relação às variáveis adicionais de controle, que representam um esforço de consideração de variáveis presentes nos questionários do diretor e do professor, nota-se a forte influência da experiência dos diretores sobre o desempenho dos alunos. Os resultados indicam que as escolas que contam com diretores com 3 a 10 anos de experiência e com diretores com 11 ou mais anos de experiência apresentam notas 6,6 e 9 pontos maiores, respectivamente, que as escolas que contam com diretores com até dois anos de experiência na função.

Dentre as variáveis dos professores testadas, considerando as que apresentavam alguma variabilidade, e com base nas regressões Stepwise, optamos por incluir a variável Tempo disciplina no modelo disposto na coluna 3 da Tabela 21. Ainda que ela não seja estatisticamente significante, sua inclusão implicou em ganho relevante de informação para o modelo. Mesmo que mais estudos sejam necessários, pode-se sugerir que a relevância desta variável tenha menos a ver com o uso do tempo do que com a relação entre o professor e a turma. Caso o efeito fosse de fato relativo ao uso do tempo em sala de aula, seria razoável que a variável que diz respeito ao tempo utilizado para ensino e aprendizagem se mostrasse mais relevante que o tempo dedicado à manutenção da disciplina das turmas.

Três variáveis tipicamente consideradas como medidas de recursos escolares - horas de aula por dia, percentual de professores com nível superior e número de alunos por turma - não foram incluídas nas regressões. As horas diárias de aula não foram consideradas porque não há variação desta variável entre as escolas municipais de São Bernardo do Campo. O 
percentual de professores com nível superior não foi considerado relevante para a explicação das notas dos alunos, tendo como base os critérios utilizados para a avaliação dos modelos e as regressões Stepwise. O mesmo ocorreu com diversas outras variáveis testadas (proporção de professores estáveis, utilização do espaço escolar pela comunidade, forma de elaboração do projeto político pedagógico foram, por exemplo, variáveis que não se mostraram significantes e não que acrescentaram informação às especificações. Portanto, não foram consideradas nos modelos finais, considerada inclusive a impossibilidade de inclusão de um grande número de variáveis). O tamanho das turmas não foi considerado por causa da alta correlação com o gasto por aluno com salários de professores.

Ressaltamos que este trabalho, baseado em um número restrito de observações, representa uma tentativa de jogar luz sobre a relação entre gastos escolares e desempenho dos alunos. Os resultados observados indicam que dados no nível da escola e agregações do gasto que guardem relação com finalidades escolares dos gastos são relevantes, como indica a literatura, para o avanço do entendimento desta relação. Outras formas de agregação dos gastos escolares e contextos diferentes, contudo, podem conduzir a outras conclusões. São necessárias, portanto, mais pesquisas, com base em maior número de observações, para que se avance no sentido de entender como os recursos importam ou podem importar para a promoção da melhoria da aprendizagem. 


\section{Considerações finais}

O objetivo central desta pesquisa foi avançar no entendimento sobre a relação entre recursos escolares, na forma de gastos por aluno, e o desempenho. Procuramos indicar que, para a compreensão de como gastos e desempenho dos alunos se relacionam, é importante que sejam considerados gastos no nível das escolas e segundo determinadas funções ou atividades escolares. Isto é, para entender como o gasto pode influenciar o desempenho dos alunos, é necessário que a informação de gasto esteja associada àquilo que ela viabiliza no cotidiano escolar.

Considerando a relevância da informação acerca de gastos no nível da escola, analisamos a literatura brasileira dedicada a estimar o custo por aluno a partir de unidades de ensino. Esta análise indicou que predomina nestes trabalhos a agregação dos gastos das escolas segundo categorias da despesa pública, sendo menor o foco em categorias de agregação dos gastos segundo as funções ou atividades escolares associadas a eles. Além disso, pode-se notar que os trabalhos dedicados a estimar custos no nível da escola, no Brasil, tendem a não estabelecer uma relação entre gastos escolares e resultados esperados da educação escolar, o que é coerente, de certa forma, com o estado do campo da educação e com o contexto do financiamento da educação no momento em que estas pesquisas foram conduzidas.

A literatura sobre custo no nível das escolas indicou ainda a predominância de gastos com pessoal nas escolas brasileiras, conclusão que se mantém no tempo e entre as diferentes etapas da educação básica. Além disso, indicamos que, para estudos que se dedicam ao estabelecimento de relações entre recursos escolares e desempenho dos alunos, a informação de custo parece ser mais apropriada que a informação de gasto ou despesa com educação, já que a informação de despesa deixa de considerar a depreciação do estoque de capital já existente nas escolas e, ao mesmo tempo, pode incluir grandes despesas que, executadas em um ano, implicam na formação de um estoque de capital que durará muitos anos, não sendo razoável esperar que estas despesas estejam associadas, de alguma forma, a variações dos resultados escolares, no mesmo período em que foram executadas.

Analisada a literatura que trata dos custos escolares e indicadas as possibilidades de construção deste tido de informação, procuramos apontar algumas das restrições dos trabalhos 
que, com base em dados agregados por município, se dedicam a estimar a relação entre gastos e desempenho dos alunos no contexto brasileiro. Estas pesquisas, que ainda são poucas no país, tendem a concluir que a variação dos gastos não é relevante para explicar a variação do desempenho dos alunos. Dentre os problemas provenientes da utilização de dados agregados da despesa pública municipal com educação, salientamos 1) a impossibilidade de separar os gastos entre anos finais e iniciais do ensino fundamental, o que seria positivo, já que as estimativas utilizam como variável a ser explicada o desempenho dos alunos do anos finais ou iniciais desta etapa, separadamente; e 2) a dificuldade de utilizar variáveis de controle adequadas, considerando que variáveis no nível do município, sobretudo as relativas ao nível socioeconômico, tendem a refletir as condições médias da população do município e não as condições dos alunos que frequentam as escolas públicas locais.

Postas as ressalvas acerca das informações de gastos agregados por município e/ou segundo categorias econômicas da despesa pública, e considerando o propósito de entender as relações entre gastos educacionais e desempenho, buscamos na literatura norte-americana abordagens possíveis para a construção e uso de dados de gastos no nível das escolas. Como indicamos, os gastos das escolas, sobretudo quando associados às funções ou atividades escolares, são essenciais para que se possa avançar no sentido de entender como os gastos com educação podem impactar o desempenho dos alunos. Dito de outra forma, a delimitação dos gastos das escolas com coordenação escolar ou com o transporte de alunos tem mais a oferecer, tendo em vista a compreensão da relação entre gastos e desempenho dos alunos, do que o conhecimento dos gastos de custeio, de capital e com pessoal ou dos gastos com educação agregados por município.

Dentre as abordagens seguidas pela literatura norte-americana, destacamos 1) a tendência de serem consideradas as diferenças de necessidade de recursos por parte das escolas, sendo estas explicadas, em grande medida, pelas diferenças de necessidade de aprendizagem dos alunos; e 2) a preocupação em estabelecer categorias de gasto que apontem para o uso dos recursos. Estas duas características, em conjunto, contribuem para que a exploração da relação entre gastos e desempenho extrapole uma simples constatação acerca da relevância ou não de gastos agregados com educação, permitindo que sejam delimitados os gastos e os usos dos recursos que são relevantes para a promoção da melhoria da aprendizagem dos alunos, 
respeitadas as diferenças destes alunos e considerado o contexto social em que estão inseridos.

Com base nas referências que tratam dos gastos no nível das escolas e da relação entre gastos e desempenho, exploramos a relação entre gastos e desempenho dos alunos da rede municipal de ensino da cidade de São Bernardo do Campo. A partir dos dados de salários, segundo a função exercida em cada escola por cada funcionário, foi proposta uma classificação para os gastos com pessoal de toda a rede, estando esta classificação em linha com algumas das funções ou atividades desempenhadas pelas escolas.

A partir destas informações, foi possível notar que os gastos por aluno variam significativamente entre as escolas da rede em questão. Além disso, foi possível constatar que o gasto por aluno apresenta relação variada com o nível socioeconômico dos alunos, a depender da categoria de gasto considerada. Dentre as principais associações entre gastos e nível socioeconômico, destacamos que o gasto por aluno com a categoria Desenvolvimento do currículo básico, que agrega gastos com professores, assistentes de classe e estagiários, tende a ser maior nas escolas que atendem alunos de nível socioeconômico mais baixo, o que pode indicar certa preocupação com equidade, por parte dos gestores da rede.

Em relação à associação entre as diferentes categorias de gastos e desempenho, é possível indicar, em primeiro lugar, que as regressões estimadas apontam uma melhora significativa da informação conforme os gastos com pessoal são desagregados, o que confirma as ressalvas feitas acerca das estimativas que utilizam dados agregados para a mensuração da relação entre gastos e desempenho. Em segundo lugar, a análise indicou que a relação entre gastos por aluno e desempenho não é homogênea entre as diferentes categorias de gasto, adquirindo sentidos opostos em alguns casos. Por fim, os resultados das regressões estimadas com base no menor nível de agregação dos gastos indicaram uma relação positiva e estatisticamente significante entre gastos com Coordenação pedagógica e o desempenho em matemática, e negativa entre os gastos com salários de Assistentes de classe e desempenho nesta mesma disciplina, controlado o nível socioeconômico dos alunos. Com base nos resultados obtidos, é possível sugerir que os gastos com coordenação pedagógica devem ser considerados em estudos futuros, que se baseiem em outras abordagens metodológicas, considerando o potencial que tais gastos podem ter para a promoção da melhoria da aprendizagem. Além 
disso, pode-se dizer que um melhor entendimento da atuação dos profissionais envolvidos com a coordenação pedagógica das escolas, a partir de questionários contextuais de testes em larga escala, pode contribuir para a compreensão de caminhos possíveis para a promoção da melhoria do ensino e da aprendizagem no Brasil.

Outras variáveis, como gastos com Gestão escolar e com salários de Professores, não se mostraram significantes nas estimativas feitas, o que não indica que estes gastos não são relevantes do ponto de vista da promoção da aprendizagem dos alunos. Estes resultados apenas apontam que, para a amostra em questão, no ano de 2013, não havia uma associação positiva ou negativa entre estes gastos e a nota em matemática na Prova Brasil. Outros trabalhos, dedicados não somente à exploração de fatores associados ao desempenho, mas também ao estudo de relações de causalidade entre as variáveis consideradas, podem obter resultados diferentes dos relatados nesta pesquisa.

Em relação às restrições do que procuramos fazer, pode-se dizer que as ressalvas apontadas, que vão da possibilidade de endogeneidade dos gastos ao baixo número de observações da amostra (55 escolas), sugerem a necessidade de estudos futuros. De toda forma, esta pesquisa parece indicar como promissoras abordagens que não se limitem a afirmar se gastos com educação são ou não relevantes para a promoção da melhoria da aprendizagem, mas que apontem, de alguma forma, quais gastos, em quais contextos, podem contribuir para que educação de qualidade seja garantida a todos.

Por fim, vale indicar que o caminho seguido para a elaboração desta pesquisa provavelmente foge ao que tradicionalmente é feito. Estudos que procuram estimar uma relação entre gastos e desempenho, em geral, apoiam-se fortemente em métodos quantitativos, mas não abordam questões relativas à construção da informação de gasto. Por outro lado, as pesquisas que trabalham de forma detalhada os dados de gastos ou de custos escolares não têm sido conduzidas no sentido de ter como um de seus objetivos a exploração da relação entre gastos e desempenho. Assim, esta pesquisa constitui uma tentativa de reunir estas duas abordagens que, juntas, podem ser úteis para uma melhor compreensão de como diferentes tipos de gastos podem estar relacionados de diferentes formas com o desempenho dos alunos. 


\section{Referências}

ABRUCIO, F. L. Gestão escolar e qualidade da educação: um estudo sobre dez escolas paulistas. Estudos \& Pesquisas Educacionais, São Paulo, v. 1, p. 241-274, 2010.

ALBERNAZ, A.; FERREIRA, F. H. G.; FRANCO, C. Qualidade e equidade na educação brasileira. Rio de Janeiro: Departamento de economia PUC - Rio, 2002 (Texto para discussão $\left.n^{\circ} 455\right)$.

ALVES, M. T. G.; FRANCO, C. A pesquisa em eficácia escolar no Brasil: evidências sobre o efeito das escolas e fatores associados à eficácia escolar. In: Brooke, N.; Soares. J. F.

Pesquisa em eficácia escolar: origem e trajetórias. Belo Horizonte: Editora UFMG, 2008.

ALVES, M. T. G; SOARES, J. F. Contexto escolar e indicadores educacionais: condições desiguais para a efetivação de uma política de avaliação educacional. Educação e Pesquisa, São Paulo, v. 39, n. 1, 177-194, jan./mar. 2013.

ALVES, F.; BONAMINO, A.; FRANCO, C. Qualidade e equidade em educação: reconsiderando o significado de "fatores intra-escolares". In: Ensaio - Avaliação e Políticas Públicas em Educação, Rio de Janeiro, v. 15, n. 55, p. 277-298, 2007.

ALVES, T. Desenvolvimento de um modelo de previsão de custos para planejamento de sistemas públicos de educação básica em condições de qualidade: uma aplicação a municípios de Goiás. Tese (Doutorado). Faculdade de economia, administração e contabilidade da USP, São Paulo, 2012.

AMARAL, L.F.L.E.; Os determinantes dos gastos educacionais e seus impactos sobre a qualidade do ensino. Dissertação (Mestrado). Faculdade de economia, administração e contabilidade da USP, São Paulo, 2011.

AMARAL, L. F. L. E.; MENEZES-FILHO, N. A relação entre gastos educacionais e desempenho escolar. Anais do XXXVI Encontro Nacional de Economia, Salvador, 2008.

ARCHIBALD, S. Narrowing in on educational resources that do affect student achievement. Peabody journal of education, 81 (4), p. 23-42, 2006.

BARBOSA FILHO, F. H.; PESSÔA, S. Retorno da educação no Brasil. Pesquisa e planejamento econômico, Rio de Janeiro, IPEA, v. 38, n. 1, abr. 2008.

BECKER, G. Investiment in human capital: a theoretical analysis. Journal of Political Economy, Part 2: Investiment in Human Beings, Chicago, v. 70, n. 5, p. 9-49, 1962.

BERNE, R.; STIEFEL, L. Student-level school resource measures. Selected papers in school finance. Washington DC: National Center for Education Statistics, 1997.

BIDDLE, B. J.; BERLINER, D. C. What research says about unequal funding for schools in America. Education Policy Reports Project. Arizona, 2002. 
BIONDI, R. L.; FELÍCIO, F. Atributos escolares e o desempenho dos estudantes: uma análise em painel dos dados do Saeb. Brasília: Instituto Nacional de Estudos e Pesquisas Educacionais Anísio Teixeira, 2007.

BONAMINO, A.; SOUSA, S. Z. Três gerações de avaliação da educação básica no Brasil: interfaces com o currículo da/na escola. Educação e Pesquisa, São Paulo, v. 38, n. 2, p. 373 388, abr./jun. 2012.

BOURDIEU, P. A miséria do mundo. Petrópolis: Vozes, 2012. 1998. . Contrafogos: táticas para enfrentar a invasão neoliberal. Rio de Janeiro: Zahar, . Homo academicus. Florianópolis: Editora UFSC, 2013. . O poder simbólico. Rio de Janeiro: Bertrand Brasil, 1989.

. Os usos sociais da ciência: por uma sociologia clínica do campo científico. São Paulo: Editora UNESP, 2004.

. Para uma sociologia da ciência. Lisboa: Edições 70, 2004.

- Questões de sociologia. Rio de Janeiro: Marco Zero, 1983.

BRASIL. (Constituição). Constituição Federal de 1988. Brasília, 1988. Disponível em: < http://www.planalto.gov.br/ccivil 03/constituicao/constituicao.htm>. Acesso em: 08 de jun. 2014.

. Emenda Constitucional $n^{\circ}$ 59, de 11 de novembro de 2009. Diário Oficial da União, Brasília, n. 256, Seção I, p. 8, 12 nov. 2009.

BRASIL. Lei $n^{\circ}$ 9.394, de 20 de dezembro de 1996. Estabelece as Diretrizes e Bases da Educação Nacional. Brasília, 1996. Disponível em: < http://www.planalto.gov.br/ccivil 03/leis/19394.htm>. Acesso em 10 jun. 2014.

CAMARGO, R. B.; OLIVEIRA, J. F.; CRUZ, R. E.; GOUVEIA, A. B. Problematização da qualidade em pesquisa de custo-aluno-ano em escolas de educação básica. Brasília: INEP, 2006.

CAMARGO, J.; PORTO JÚNIOR, S. S.; O efeito do tamanho da turma sobre o desempenho escolar: uma avaliação do impacto da "enturmação" no ensino fundamental do Rio Grande do Sul. Porto Alegre: UFRGS/FCE/DERI, 2014 (Texto para discussão, nº 2/2014).

CARREIRA, D.; PINTO, J. M. R. Custo aluno-qualidade inicial: rumo à educação pública de qualidade no Brasil. São Paulo: Global, 2007.

CASTRO, C. M.; ASSIS, M. P.; OLIVEIRA, S. F. Ensino técnico: desempenho e custos. Rio de Janeiro: IPEA, 1972

CATANI, D. B.; GALLEGO, R. C. Avaliação. São Paulo: Unesp, 2009. 
CHAMBERS, J. Public school teacher cost differences across the United States. Washington D. C., National Center for Education Statistcs, 1995.

CHUDGAR, A.; LUSCHEI, T. F. National income, income inequality, and the importance of schools: a hierarchical cross-national comparison. American educational Research Journal, 46(3), p. 626-658, 2009.

COLEMAN, J. S. et al. Equality of educational opportunity. Washington: U.S. Government Printing Office, 1966.

CONLEY, D. T.; PICUS, L. O. Oregon's quality education model: linking adequacy and outcomes. Educational policy, 2003.

CURI, A. Z.; MENEZES-FILHO, N. A relação entre educação pré-primária, salários, escolaridade e proficiência escolar no Brasil. Estudos econômicos. São Paulo, v. 39, n. 4, out./dez. 2009.

DAVIES, N. Fundeb: solução ou remendo para o financiamento da educação básica? In: Gouveia, Andréa B.; Souza, Ângelo R.; Tavares, Taís M. (Orgs.). Conversas sobre financiamento da educação. Curitiba: Ed. da UFPR, 2006.

DIAZ, M. D. M. Qualidade do gasto público municipal em ensino fundamental no Brasil. Revista de economia política. São Paulo, v. 32, n. 1, p. 128-141, jan./mar. 2012.

DUARTE, M. R. T.; SANTOS, M. R. S. Gasto direto por aluno e condições de oferta do ensino em escolas de educação básica do Estado de Minas Gerais. In: FARENZENA, N. (Org.). Custos e condições de qualidade da educação em escolas públicas: aportes de estudos regionais. Brasília: INEP/MEC, 2005.

FARENZENA, N. Custos e condições de qualidade da educação em escolas públicas: aportes de estudos regionais. Brasília: INEP/MEC, 2005.

FERRÃO, M. E.; BELTRÃO, K. I.; FERNANDES, C.; SANTOS, D.; SUÁREZ, M.;

ANDRADE, A.C. O SAEB - Sistema Nacional de Avaliação da Educação Básica: objetivos, características e contribuições na investigação da escola eficaz. Revista Brasileira de estudos da população, Rio de Janeiro, v.18, n. 1/2, jan./dez. 2001.

FERGUSON, R. F. Paying for public education: new evidence on how and why Money matters. Harvard Journal on Legislation, v. 28, n. 465, 1991.

FERTIG, M.; WRIGHT, R. E. School quality, educational attainment and aggregation bias. Institute for the study of labor - Discussion paper series, n. 994, 2004.

FRANCO, A. M. P. Os determinantes da qualidade da educação no Brasil. Tese (Doutorado em Economia) - Faculdade de economia, administração e contabilidade da USP, São Paulo, 2008 .

FRANCO, C; FERNANDES, C; SOARES, J. F; BELTRÃO, K; BARBOSA, M. E; ALVES, M. T. G. O referencial teórico na construção dos questionários contextuais do Saeb 2001. Estudos em avaliação educacional, São Paulo, n. 28, p. 39-74, jul-dez/2003. 
FRANCO, C.; ORTIGÃO, I.; ALBERNAZ, A.; BONAMINO, A.; AGUIAR, G.; ALVES, F.; SÁTYRO, N.; Qualidade e equidade em educação: reconsiderando o significado de "fatores intra-escolares". Ensaio: aval. pol. públ. educ., Rio de Janeiro, v.15, n.55, p. 277-298, abr./jun. 2007.

GATTI, B. A. A avaliação educacional no Brasil: experiências, problemas, recomendações. Estudos em avaliação educacional, São Paulo, n. 10, p. 67-80, 1994.

GIACOMONI, J. Orçamento público. São Paulo: Atlas, 2010.

GUISBOND, L.; NEILL, M.; SCHAEFFER, B. A década de progresso educativo perdida sob a NCLB: que lições tirar desse fracasso político? Educação e sociedade, Campinas, v. 33, n. 119, p. 405-430, abr./jun. 2012.

HAIR, J. F. et al. Análise multivariada de dados. Porto Alegre: Artmed Editora S.A., 2009.

HANUSHEK, E. A. An exchange: part II: money might matter somewhere: a response to Hedges, Laine, and Greenwald. Educational researcher, vol. 23, n. 4, p. 5-8, 1994.

. Assessing the effects of school resources on student performance: an update. Educational evaluation and policy analysis, vol. 19, n. 2, p. 141-164, 1997.

. The economics of schooling: production and efficiency in public schools. Journal of economic literature, vol. 24, n. 13, p. 1141-1177, 1986. 64-98, 2003. . The failure of input-based schooling policies. The economic journal, v. 113, p.

. The impact of differential expenditures on school performance. Educational Researcher, v. 18, n. 4, p. 45-51, 1989.

. Throwing Money at schools. Journal of policy analysis and management, v. 1, n.1, p. 19-41, 1981 .

HANUSHEK, E. A.; RIVKIN, S. G.; TAYLOR, L. L. Aggregation and the estimated effects of school resources. The review of economics and statistics, v. 78, issue 4, p. 611-627, 1996.

HEDGES, L.; LAINE, R. D.; GREENWALD, R. Does money matter? A meta-analysis of the effects of differential schools inputs on student outcomes. Educational Researcher, v. 23, n. 3, p. 5-14, 1994.

INEP. Indicador de nível socioeconômico das escolas de educação básica (Inse). Brasília, 2014.

KIMBALL, R. L. Where does the money go? An analysis of student level resource allocation at the school level. PhD in Education. School of Education, University of Southern California, 2009.

LEVY, S.; CAMPINO, A. C.; NUNES, E. M. Análise econômica do sistema educacional de São Paulo. São Paulo: IPE - USP, 1970. 
MACHADO, N. Sistema de informação de custo: diretrizes para integração ao orçamento público e à contabilidade governamental. Tese (Doutorado). Faculdade de economia, administração e contabilidade da USP, São Paulo, 2002.

MARTINS, E. Contabilidade de Custos. São Paulo: Atlas, 2003.

MELCHIOR, J. C. A. Financiamento da educação: captação e aplicação de recursos financeiros numa perspectiva democrática. In: Projeto educação. Brasília: Fundação Universidade de Brasília, 1979.

MENEZES-FILHO, N.; Os Determinantes do Desempenho Escolar do Brasil. São Paulo: Instituto Futuro Brasil, 2007.

MENEZES-FILHO, N.; OLIVEIRA, A. P. A relação entre gastos em educação e desempenho escolar nos municípios brasileiros: uma análise com dados em painel. In: Fernandes, R.; Souza, A. P. F.; Botelho, F.; Scorzafave, L. G. (Orgs.). Políticas públicas educacionais e desempenho escolar dos alunos da rede pública de ensino. São Paulo: FUNPEC - Editora, 2014.

MENEZES-FILHO, N.; PAZELLO, E. Does money in school matter? Evaluating the effects of Fundef on wages and test scores in Brazil. Rio de Janeiro: FGV, 2004.

MENEZES-FILHO, N.; PAZELLO, E. Do teacher's wages matter for proficiency? Evidence from a funding reform in Brazil. Economics of Education Review, v. 26, p. 660-672, 2007.

MONK, D. H; BRENT, B. O; ROELLKE, C. F; Teacher resource use within New York State secondary schools. Developments in school finance. Washington D. C., National Center for Education Statistcs, p. 37-67, 1996.

MONK, D.; PIJANOWSKI, J. C.; HUSSAIN, S. How and where the education dollar is spent. Financing shcools, v. 7, n. 3, 1997.

MONTEIRO, J. Gasto público em educação e desempenho escolar. Revista brasileira de economia, Rio de Janeiro, v. 69, n. 4, p. 467-488.

NETO, J. J. S; JESUS, G. R. Uma escala para medir a infraestrutura escolar. Estudos em avaliação educacional, São Paulo, v. 24, n. 54, p. 78-99, jan-abr/2013.

NICHCY. Categories of disability under IDEA. Washington D.C., National Dissemination Center for Children with Disabilities, 2012.

ODDEN, A.; ARCHIBALD, S.; FERMANICH, M.; GROSS, B. Defining school-level expenditure structures that reflect educational strategies. Journal of Education Finance, 28 (3), p. 323-356, 2003.

ODDEN, A. 10 strategies for doubling student performance. California: Corwin, 2009.

OLIVEIRA, R. P. A pesquisa em financiamento da educação. In: Gouveia, Andréa B.; Souza, Ângelo R.; Tavares, Taís M. (Orgs.). Conversas sobre financiamento da educação. Curitiba: Ed. da UFPR, 2006. 
. Da universalização do ensino fundamental ao desafio da qualidade: uma análise histórica. In: Educação e Sociedade, Campinas, v. 28, n. 100 - Especial, p. 661-690, out. $2007 \mathrm{a}$.

. O direito à educação. In: OLIVEIRA, Romualdo P.; Adrião, Theresa (Orgs.). Gestão, financiamento e direito à educação: análise da Constituição Federal e da LDB. 3. ed. São Paulo: Xamã, 2007.

. Educação e cidadania: O direito à educação na Constituição de 1988 da República Federativa do Brasil. Tese (Doutorado). Faculdade de Educação da USP, São Paulo, 1995.

OLIVEIRA, R. P.; ARAÚJO, G. C. Qualidade do ensino: uma nova dimensão da luta pelo direito à educação. In: Revista Brasileira de Educação/ANPED, Rio de Janeiro, n. 28, 2005, p. 5-23.

OLIVEIRA, R. P.; BAUER, A.; FERREIRA, M. P.; MINUCI, E. G.; LISAUSKAS, F.; ZIMBARG, R.; CASSETTARI, N.; CARVALHO, M.; GALVÃO, F. V. Análise das desigualdades intraescolares no Brasil. In: Estudos \& Pesquisas Educacionais, n. 4, nov. 2013, p. 19-112.

PARO, V. H. Estudo comparativo de custo-aluno nos diversos graus e modalidades de ensino. São Paulo: ATPCE: FCC, 1981.

PICUS, L. O. Does Money matter in education? A policymaker's guide. Selected papers in school finance, Washington D. C., National Center for Education Statistcs, p. 16-36, 1995.

. Student-level finance data: wave of the future? The Clearing House, New York, v. 74, n. 2, p. 75-80, nov./dec., 2000.

. The collection and use of school level data. Prepared for the Joint Legislative Audit and Review Committee, Washington State Legislature, 1998.

PICUS, L. O; PETERNICK, L. Developing student resource variables for the early childhood longitudinal survey. Developments in school finance, Washington D. C., National Center for Education Statistcs, p. 107-128, 1998.

PICUS, L. O.; ODDEN, A.; APORTELA A.; MANGAN, M. T., GOETZ, M. Implementing school finance adequacy: school level resource in Wyoming following adequacy-oriented finance reform. California: Lawrence O. Picus and Associates, 2008.

RAUTER, R.; LAROS, J. A.; JESUS, G. R. Questionários contextuais do Saeb: análise qualitativa baseada nos resultados da análise fatorial. REICE: Revista Eletrônica Iberoamericana sobre Calidad, Eficacia y Cambio en Educación, Madrid, v. 5, n. 2e, p. 5668, 2007.

RESCHOVSKY, A.; IMAZEKI, J. Achieving educational adequacy through achool finance reform. Research report series, RR-045, University of Pennsylvania: Consortium for policy research in education, 2000. 
SCHULTZ, T. W. Capital formation by education. The Journal of Political Economy, Chicago, v. 68, n. 6, p. 571-583, dez. 1960.

. O valor econômico da educação. Rio de Janeiro: Zahar Editores, 1967.

. The rate of return in allocating investment resources to education. Economic Papers, n. 27, p. 40-55, jun. 1968.

SCHWARTZ, A. E.; ROSS, R.; STIEFEL, L. Why do some schools get more and other less? An examination of school-level funding in New York City. Working Paper 09-10. Institute for Education and Social Policy, 2009.

SILVA, L. M.; Contabilidade governamental: um enfoque administrativo da nova contabilidade pública. São Paulo: Atlas, 2009.

SMITH, A. A riqueza das nações: investigação sobre sua natureza e suas causas. São Paulo: Nova Cultural, 1996.

SOARES, J. F. Melhoria do desempenho cognitivo dos alunos do ensino fundamental. Cadernos de pesquisa, v. 37, n. 130, p. 135-160, jan./abr. 2007.

. O efeito da escola no desempenho cognitivo de seus alunos. REICE: Revista Eletrônica Iberoamericana sobre Calidad, Eficacia y Cambio en Educación, Madrid, v. 2, n. 002, p. 83-104, jul./dec. 2004.

SOUZA, R. S. O financiamento da educação na escola: análise dos recursos disponíveis em 13 escolas públicas no Estado do Paraná. A pesquisa em financiamento da educação. In: Gouveia, Andréa B.; Souza, Ângelo R.; Tavares, Taís M. (Orgs.). Conversas sobre financiamento da educação. Curitiba: Ed. da UFPR, 2006.

VERHINE, R. E. Custo-aluno-qualidade em escolas de educação básica - $2^{\mathrm{a}}$ etapa. Brasília: INEP, 2006.

. Determinação de custos educacionais: uma análise panorâmica do estado da arte. Revista Educação - PUC/RS, v.21, n. 35, p. 107-122, 1998.

VIGNOLES, A.; LEVACIC, R.; WALKER, J.; MACHIN, S.; REYNOLDS, D. The relationship between resource allocation and pupil attainment: a review. London: Centre for economics of education, 2000.

XAVIER, A. C. R.; MARQUES, A. E. S. Custo direto de funcionamento das escolas públicas de $1^{\circ}$ grau da região sul. Brasília: MEC/SEB, 1988.

WALZER, M. Esferas da justiça: uma defesa do pluralismo e da igualdade. São Paulo: Martins Fontes, 2003.

WALTENBERG, F. D. Teorias econômicas de oferta de educação: evolução histórica, estado atual e perspectivas. Educação e pesquisa, São Paulo, v. 32, n. 1, p. 117-136, jan./abr. 2006. 
WOOLDRIDGE, J. M. Introdução à econometria: uma abordagem moderna. São Paulo: Pioneira Thomson Learning, 2006. 


\section{ANEXOS}

ANEXO A - TABELA ORIGINAL DE INDICADORES DE RECURSOS, CONFORME PROPOSTA POR ODDEN ET AL (2003)

\section{School Resource Indicators}

School Building Size

School Unit Size

Percent Low Income

Percent Special Education

Percent ESL/LEP

Expenditures Per Pupil

Professional Development (expenditures per teacher)

Special Academic Focus of School/Unit

Length of Instructional Day

Length of Class Periods
Length of Reading Class (Elementary)

Length of Mathematics Class (Elementary)

Reading Class Size (Elementary)

Mathematics Class Size (Elementary)

Regular Class Size (Elementary)

Length of Core* Class Periods (Secondary)

Core Class Size (Secondary)

Non-Core Class Size (Secondary)

Percent Core Teachers

*Math, English/LA, Science, \& Social Studies

FONTE: ODDEN et al, 2003, p. 330. 


\section{ANEXO B - TABELA ORIGINAL DE ESTRUTURA DE GASTOS ESCOLARES, CONFORME PROPOSTA POR ODDEN ET AL (2003)}

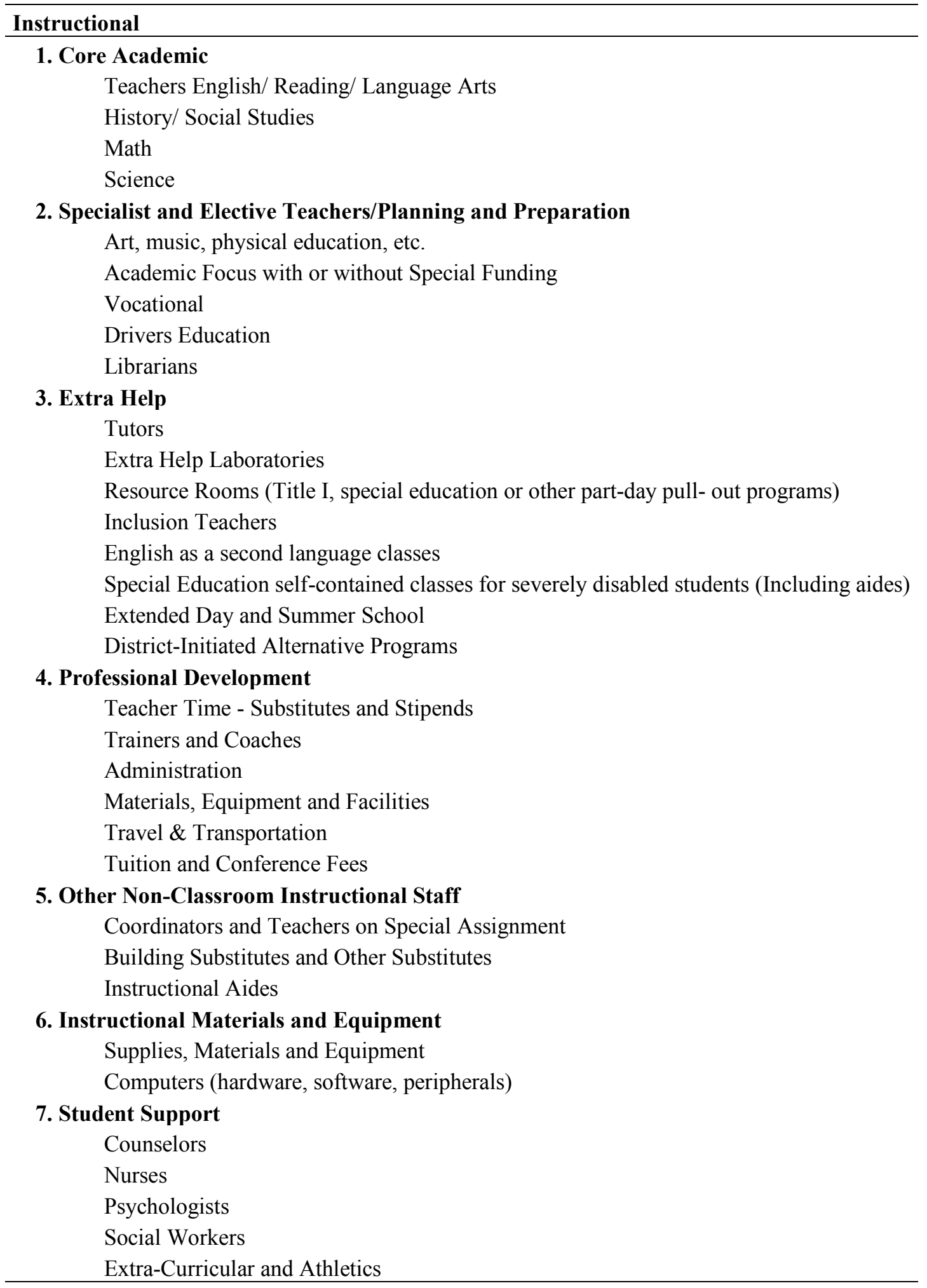

Non-Instructional

8. Administration 
9. Operations and Maintenance

Custodial

Utilities

Security

Food Service

FONTE: ODDEN et al, 2003, p. 330. 